\title{
TSUNAMI INUNDATION MAPS OF THE VILLAGES OF CHENEGA BAY AND NORTHERN SAWMILL BAY, ALASKA
}

D.J. Nicolsky, E.N. Suleimani, and R.D. Koehler

Published by

STATE OF ALASKA 



\section{TSUNAMI INUNDATION MAPS OF THE VILLAGES OF CHENEGA BAY AND NORTHERN SAWMILL BAY, ALASKA}

D.J. Nicolsky, E.N. Suleimani, and R.D. Koehler

Report of Investigations 2014-3

State of Alaska

Department of Natural Resources

Division of Geological \& Geophysical Surveys 


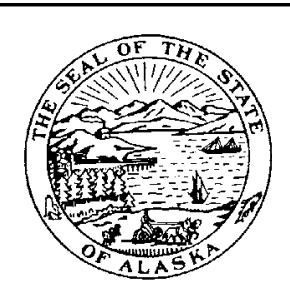

\section{STATE OF ALASKA}

Sean Parnell, Governor

\section{DEPARTMENT OF NATURAL RESOURCES}

Joe Balash, Commissioner

\section{DIVISION OF GEOLOGICAL \& GEOPHYSICAL SURVEYS}

Steve Masterman, State Geologist and Director

Publications produced by the Division of Geological \& Geophysical Surveys (DGGS) are available for free download from the DGGS website (www.dggs.alaska.gov). Publications on hard-copy or digital media can be examined or purchased in the Fairbanks office:

\section{Alaska Division of Geological \& Geophysical Surveys 3354 College Rd., Fairbanks, Alaska 99709-3707 \\ Phone: (907) 451-5020 Fax (907) 451-5050 \\ dggspubs@alaska.gov www.dggs.alaska.gov}

Alaska State Library

State Office Building, 8th Floor 333 Willoughby Avenue

Juneau, Alaska 99811-0571

Elmer E. Rasmuson Library University of Alaska Fairbanks Fairbanks, Alaska 99775-1005
Alaska Resource Library \& Information Services (ARLIS)

3150 C Street, Suite 100

Anchorage, Alaska 99503-3982

University of Alaska Anchorage Library 3211 Providence Drive Anchorage, Alaska 99508-4614 


\section{CONTENTS}

Abstract 1

Introduction. .1

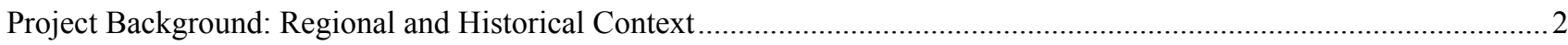

Setting.

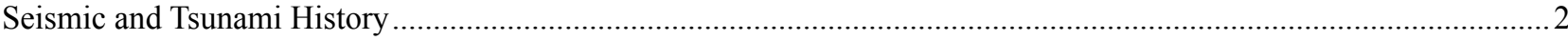

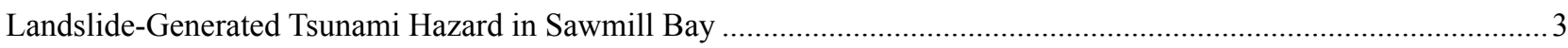

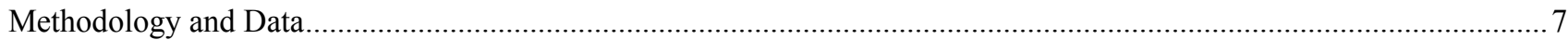

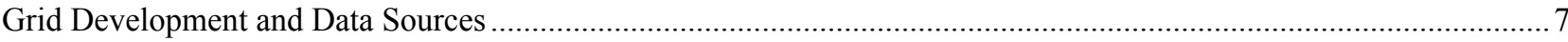

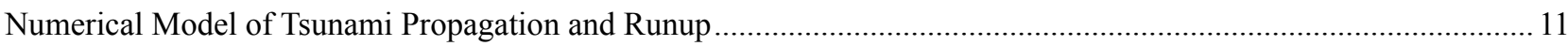

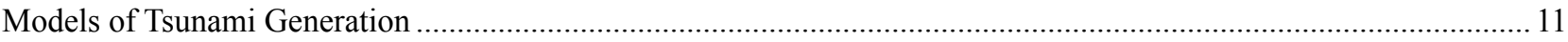

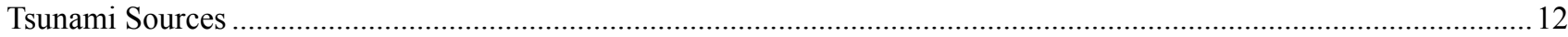

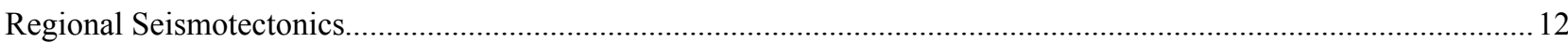

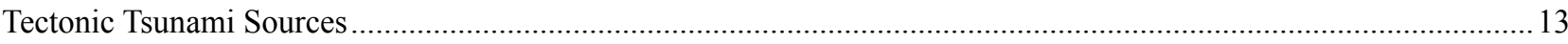

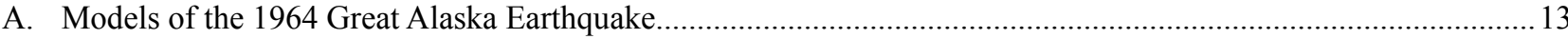

Scenario 1. Repeat of the 1964 event: Source function based on coseismic deformation interpolated from data by Plafker (1969) and referred to as the Plafker Deformation Model (PDM)....

Scenario 2. Repeat of the 1964 event: Source function based on coseismic deformation model by Johnson and others (1996) (JDM)

Scenario 3. Repeat of the 1964 event: Source function based on coseismic deformation model by Suito and Freymueller (2009) (SDM)

B. Models of a Multi-Segment Great Alaska Earthquake .............................................................................. 16

Scenario 4. Multi-Segment JDM event: Source function based on extension of the JDM................................ 16

Scenario 5. Multi-Segment SDM event: Source function based on extension of the SDM................................. 16

Scenario 6. Rupture of the Yakutat-Yakataga segment ............................................................................. 17

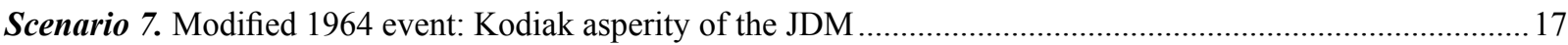

Scenario 8. Modified 1964 event: Kodiak asperity of the SDM .................................................................. 17

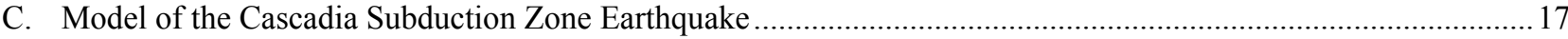

Scenario 9. Rupture of the Cascadia zone, including portions of the margin along the British Columbia

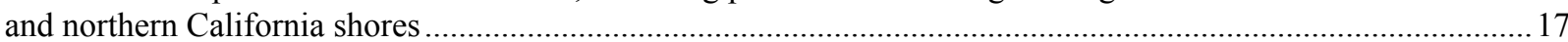

D. Other Tectonic Source Models of Hypothetical Tsunamigenic Earthquakes.................................................17

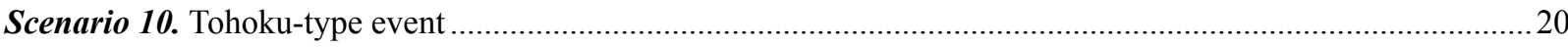

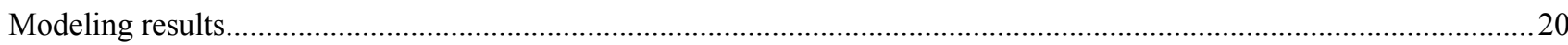

Numerical modeling of the 1964 tsunami in Sawmill Bay: Model verification ....................................................20

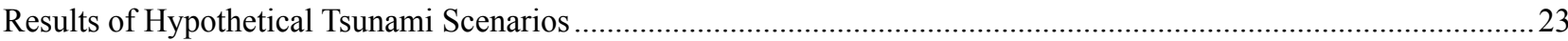

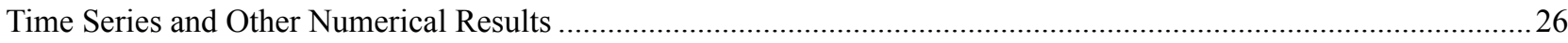

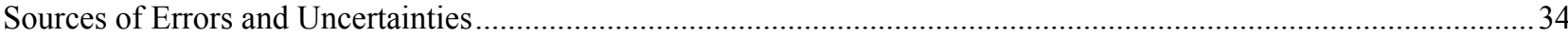

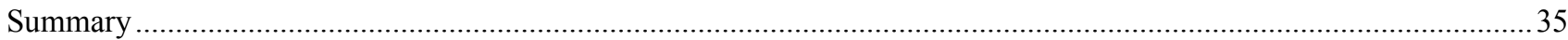

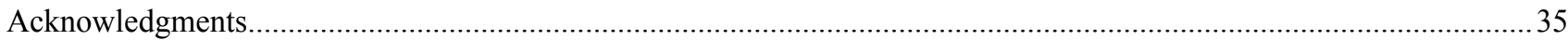

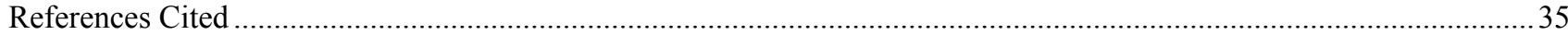




\section{FIGURES}

Figure 1. Map of south-central Alaska, showing major faults and the rupture zone of the 1964 Great Alaska Earthquake

2. Distribution and intensity of wave damage in Sawmill Bay and Elrington and Latouche passages.

3. Earthquakes in south-central Alaska

4. Locations of submarine slides in southern Prince William Sound and Gulf of Alaska

5. Telescoping embedded bathymetry/topography grids for numerical modeling of tsunami propagation and runup

6. Locations of real-time kinematic (RTK) GPS measurements around the community and airport

7. Measurement of sea level (WGS84) datum and relation of WGS84 to MHHW datum; and predicted water-level dynamics in Sawmill Bay, with fitted GPS measurements of water level in MHHW datum .......... 10

8. Map of south-central Alaska, showing rupture zone of the 1964 Great Alaska Earthquake and divisions of the Alaska-Aleutian megathrust

9. Vertical and horizontal displacements in the Prince William Sound region in scenarios 1-3 ….................... 15

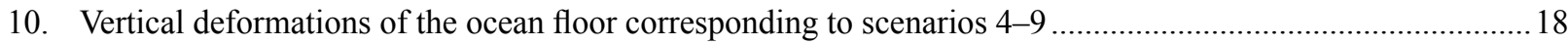

11. Contour plot of the reconstructed interseismic slip deficit, an accumulation of the potential displacement on the fault during the earthquake

12. Discretization of plate interface model into a set of rectangles used to compute the coseismic vertical displacement

13. Proposed slip distribution along the plate interface for hypothetical Tohoku-type $M_{w} 9.0$ events in the Gulf of Alaska region, and computed vertical ground surface deformation related to the proposed slip distributions in scenario 10 .

14. Computed water level at points 18,6 , and 19 for the cases of PDM, JDM, and SDM ................................24

15. Modeled runup heights in Sawmill Bay and vicinity and Crab Bay during the 1964-type events....................25

16. Reconstructed tide level and modeled water level in Sawmill Bay at points 17 and 18 after the 1964 earthquake

17. Modeled potential maximum inundation by tectonic waves ……..............................................................28

18. Maximum composite potential inundation for all scenarios near the community of Chenega Bay, and the maximum composite flow depths over dry land

19. Maximum composite potential inundation for all scenarios in the western part of Sawmill Bay near the Armin F. Koernig hatchery, and the maximum composite flow depths over dry land.

20. Maximum composite potential inundation for all scenarios in the southern part of Iktua Bay, and the maximum composite flow depths over dry land

21. Maximum composite potential inundation for scenarios 1-5 near the community of Chenega Bay, and the maximum composite flow depths over dry land....

22. Maximum composite potential inundation for scenarios 1-5 in the western part of Sawmill Bay near the Armin F. Koernig hatchery, and the maximum composite flow depths over dry land ..

23. Maximum composite potential inundation for scenarios 1-5 in the southern part of Iktua Bay, and the maximum composite flow depths over dry land 


\section{TABLES}

Table 1. Nested grids used to compute propagation of tsunamis generated in the Gulf of Alaska to the community of Chenega Bay

2. All hypothetical scenarios used to model tsunami runup in Sawmill Bay ........................................................ 16

3. Fault parameters for the Yakataga-Yakutat (YY) segment........................................................................ 17

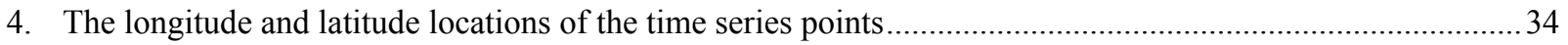

\section{APPENDIX A}

Appendix A-1. Locations of time series points in Sawmill Bay, as well as in Elrington, Latouche, and Prince of Wales passages, and near the community of Chenega Bay ……....................................... 39

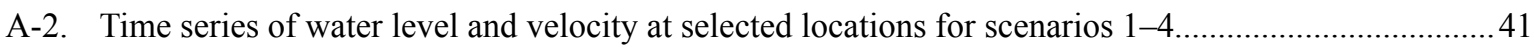

A-3. Time series of water level and velocity at selected locations for scenarios 6, 7, 9, and 10 . 



\title{
TSUNAMI INUNDATION MAPS OF THE VILLAGES OF CHENEGA BAY AND NORTHERN SAWMILL BAY, ALASKA
}

\author{
D.J. Nicolsky ${ }^{1}$, E.N. Suleimani ${ }^{1}$, and R.D. Koehler ${ }^{2}$
}

\begin{abstract}
Potential tsunami hazards for the community of Chenega Bay, located on Evans Island between Sawmill and Crab bays, were evaluated by numerically modeling the extent of inundation from tsunami waves generated by earthquakes. Tsunami scenarios include a repeat of the tsunami triggered by the 1964 Great Alaska Earthquake, as well as tsunamis generated by a hypothetically extended 1964 rupture, a hypothetical Cascadia megathrust earthquake, a hypothetical earthquake in the Kodiak asperity of the 1964 rupture, and a hypothetical Tohoku-type rupture in the Gulf of Alaska region. Results of numerical modeling are verified by simulations of the tectonic tsunami observed in Chenega Cove during the 1964 earthquake. The results presented here are intended to provide guidance to local emergency management agencies in tsunami-hazard assessment, evacuation planning, and public education, to reduce damages from future tsunami hazards.
\end{abstract}

\section{INTRODUCTION}

Subduction of the Pacific plate under the North American plate has resulted in numerous great earthquakes and tsunamis, with high potential to generate future damaging tsunamis in Alaska. The Aleutian megathrust, the region where the Pacific plate is being subducted, is the most seismically active tsunamigenic fault zone in the U.S. (fig. 1). Several historic tsunamis that were generated by earthquakes along the Alaska-Aleutian subduction zone have impacted exposed locations around the Pacific Ocean and resulted in widespread damage and loss of life. Tsunamis originating in the vicinity of the Alaska Peninsula, Aleutian Islands, and the Gulf of Alaska are considered to be a near-field hazard for Alaska, and can reach Alaska's coastal communities within minutes of an earthquake. Minimizing the loss of lives and property from tsunami inundation is dependent on community preparedness and an understanding of potential coastal zone flooding in the event of a local or distant tsunami.

On March 27, 1964, the Prince William Sound area of Alaska was struck by the largest earthquake ever recorded in North America. This $\mathrm{M}_{\mathrm{w}} 9.2$ megathrust earthquake generated the most destructive tsunami in Alaska history and, farther south, impacted the west coasts of the United States and Canada. In addition to the major tectonic tsunami generated by an ocean-floor displacement between the trench and coastline, numerous local tsunamis were generated by landslides in coastal Alaska (Plafker and others, 1969). They arrived as early as a minute and a half from the beginning of shaking, leaving no time for warning or evacuation. Of the 131 fatalities associated with this earthquake, 122 were caused by tsunamis (Lander, 1996). Local tsunamis caused most of the damage and accounted for 76 percent of tsunami fatalities in Alaska.

The original village of Chenega, located on Chenega Island in western Prince William Sound (fig. 2), was destroyed by ocean waves of uncertain origin during the earthquake (Plafker and others, 1969). Following the tsunami, the village was abandoned and many survivors settled in Tatitlek, Valdez, and other areas of the state. Decades later, former residents of Chenega established the village of Chenega Bay on Evans Island between Sawmill and Crab bays in the southwestern part of Prince William Sound. In Sawmill Bay, at the present location of the village, locally generated waves during the 1964 tsunami caused damage to residential and commercial buildings along the coast. For example, the waves destroyed a dock, and vessels and boats were beached or carried away (Plafker and others, 1969). Two residents narrowly escaped drowning, and one person drowned in Crab Bay (Plafker and others, 1969). Therefore, comprehensive inundation mapping and development of tsunami evacuation maps are essential to reduce future economic and social losses in Chenega Bay in the event of potential future tsunamis.

The production of tsunami evacuation maps for a community consists of several stages. First, we develop hypothetical tsunami scenarios on the basis of credible potential tsunamigenic earthquakes and submarine landslides, if credible landslide scenarios exist. Then we perform model simulations for each scenario. To validate the models, results are compared with historical tsunami observations, if such data exist. Finally, we develop a 'worst case' inundation line that encompasses the maximum extent of flooding based on model simulation of all source scenarios and historical observations. The 'worst case' inundation line becomes a basis for local tsunami-hazard planning and development of evacuation maps.

The tsunami inundation maps of Chenega Bay described in this report represent the results of continuous efforts between state and federal agencies ${ }^{3}$ to produce inundation maps for many of Alaska's coastal communities. In this report, we generally provide both metric and imperial units of measure. If it is necessary to quote existing data, we state the data in

\footnotetext{
${ }^{1}$ Alaska Earthquake Center, Geophysical Institute, University of Alaska, P.O. Box 757320, Fairbanks, AK 99775-7320; djnicolsky@alaska.edu; elena@gi.alaska.edu

${ }^{2}$ Alaska Division of Geological \& Geophysical Surveys, 3354 College Rd., Fairbanks, AK 99709-3707; richard.koehler@alaska.gov

${ }^{3}$ To help mitigate the hazard that earthquakes and tsunamis pose to Alaska coastal communities, the Alaska Tsunami Mapping Team (ATMT) was created It consists of personnel from the Geophysical Institute at the University of Alaska Fairbanks and from the State of Alaska Division of Geological \& Geophysical Surveys. The ATMT participates in the National Tsunami Hazard Mitigation Program by evaluating and mapping potential inundation of selected parts of the Alaska coastline using numerical tsunami modeling.
} 


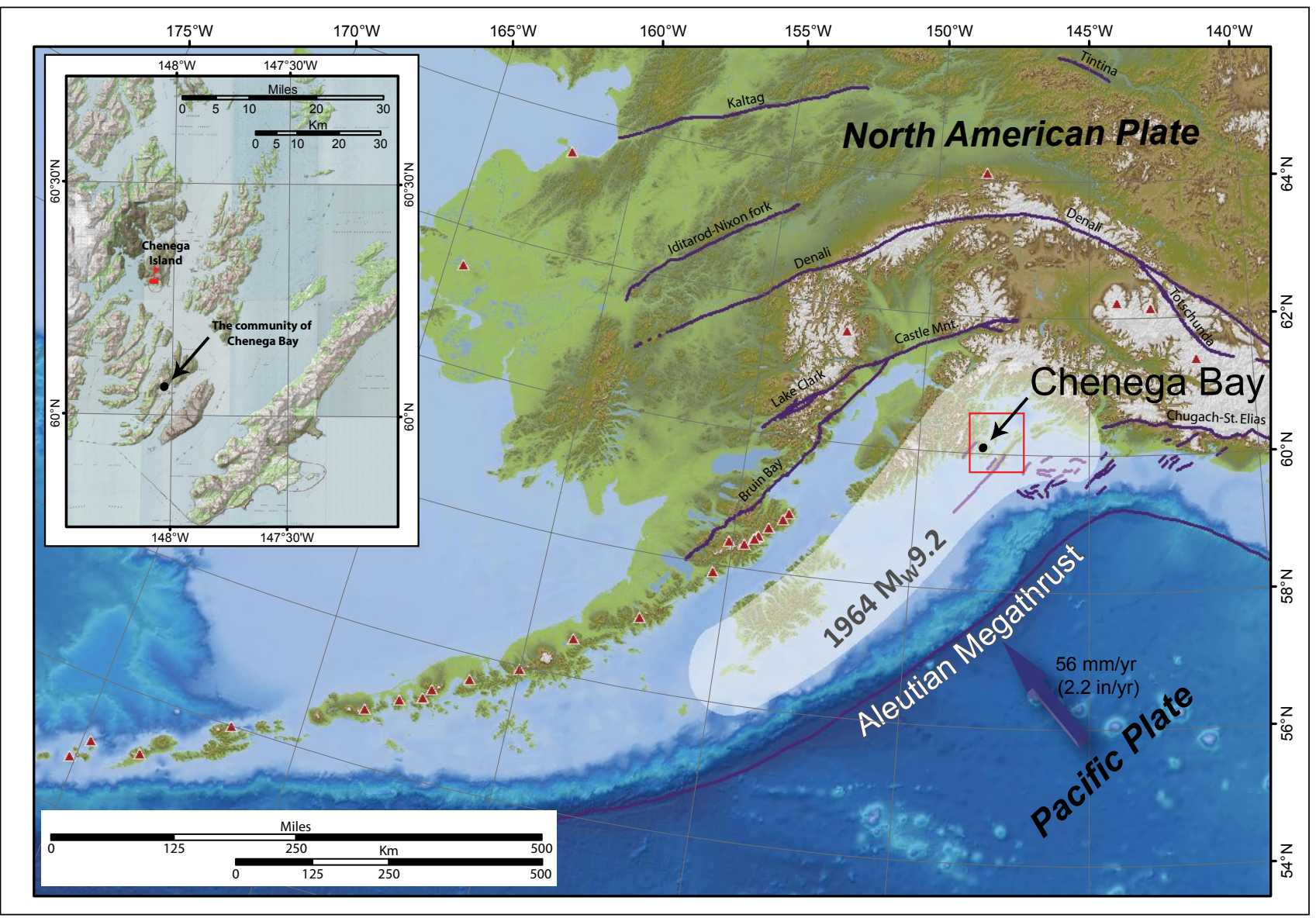

Figure 1. Map of south-central Alaska, showing major faults (dark purple lines) and the rupture zone of the 1964 Great Alaska Earthquake (light shaded area). Red triangles indicate active volcanoes. Red box shows location of the inset map. The red flag on the inset map marks the location of the community before the 1964 earthquake. The arrow in the inset points to the current location of the community.

the original and metric units of measure. Recall that one foot $(1 \mathrm{ft})$ is approximately 0.305 meters $(0.305 \mathrm{~m})$, and one mile (1 mi) is approximately 1.609 kilometers $(1.609 \mathrm{~km})$.

\section{PROJECT BACKGROUND: REGIONAL AND HISTORICAL CONTEXT}

\section{SETTING}

The original Alutiiq village of Chenega was established on the southern tip of Chenega Island in the late 1700s. During the 1964 earthquake, all buildings except one house and the school were washed away by the ocean waves, and 23 of 75 inhabitants were lost to the sea (Plafker and others 1969). In 1984, the community of Chenega Bay was established on Evans Island between Sawmill Bay and Crab Bay at $60^{\circ} 04^{\prime} \mathrm{N}$ Latitude and $148^{\circ} 01^{\prime} \mathrm{W}$ Longitude. The site is about $68 \mathrm{~km}$ (42 mi) southeast of Whittier and $167 \mathrm{~km}$ (104 mi) southeast of Anchorage and can be accessed only by water or air. According to the Alaska Department of Commerce, Community, and Economic Development, 83 residents lived in Chenega Bay in 2011 (Alaska Division of Community and Regional Affairs [DCRA], 2012).

During the 1964 earthquake, only several homes and three canneries were located in Sawmill Bay. The infrastructure has developed considerably since the 1964 event. An existing salmon cannery was converted into Armin F. Koernig Hatchery, a breeding facility for pink and chum salmon. A community hall, an office building, a school, two teachers' houses, a church, community store, and more than 20 other houses were constructed to re-establish the village in 1984. Two lodges, about $1.5 \mathrm{~km}$ (1 mi) away from Chenega Bay, provide some accommodation for tourists and visitors. In addition, Chenega Bay has a harbor, a $0.92 \mathrm{~km}(0.57 \mathrm{mi})$ lighted gravel airstrip, a seaplane landing area, and an Alaska Marine Highway ferry terminal. The village of Chenega Bay is considered a potential place of refuge in case of emergencies and is also a depot for oil spill response equipment. Much of the economic activity and infrastructure is on or near the coast, and hence is vulnerable to potential tsunamis.

\section{SEISMIC AND TSUNAMI HISTORY}

Crab and Sawmill bays on Evans Island are in the southwestern corner of Prince William Sound, and lie above the Alaska-Aleutian megathrust, where the Pacific and North American plates converge at a rate of up to $56 \mathrm{~mm}$ (2.2 in) per year (DeMets and others, 1990; Page and others, 1991). Here in the northeastern section of the Alaska-Aleutian megathrust, the megathrust is strongly coupled and has a 
shallow dip angle of about 8-10 degrees in the Kodiak Island area and 3-4 degrees in the Prince William Sound area (Brocher and others, 1994). This segment of the megathrust has produced some of the largest earthquakes in the world, such as the $M_{w} 9.2$ Great Alaska Earthquake of 1964 that caused $285,000 \mathrm{~km}^{2}\left(110,000 \mathrm{mi}^{2}\right)$ of surface deformation (Plafker, 1969).

Besides the 1964 Great Alaska Earthquake, there are other numerous earthquakes in south-central Alaska; their spatial distribution is shown in figure 3. Doser and Brown (2001) found that the central and southern Kenai Peninsula have been seismically quiet at the $M_{w} \geq 5$ level since the 1964 event, while the Prince William Sound area continues to experience seismic activity similar to that prior to the 1964 earthquake. Among all the earthquakes in the Prince William Sound area, the $M_{w} 9.21964$ Great Alaska Earthquake is of special interest to tsunami hazard mitigation in the town of Chenega Bay. A description of the events in Sawmill Bay and eyewitness accounts of the earthquake were documented in Plafker and others (1969) and are briefly recounted here.

According to eyewitnesses, the earthquake lasted from 4 to 5 minutes in the Sawmill Bay area. As a result of the earthquake, the Sawmill Bay area was uplifted by about 2.4-2.7 $\mathrm{m}(8-9 \mathrm{ft})$ and laterally shifted by about $18 \mathrm{~m}(60 \mathrm{ft})$ in the south-southeast direction (Plafker, 1969). The shaking was described as a northwest-southeast swaying motion that later became almost vertical. Some poorly constructed chimneys cracked and toppled, but no damage caused by the seismic vibration was reported at cannery docks. The coseismic uplift in Sawmill Bay required modification of the dock facilities.

An eyewitness to the 1964 event in Sawmill Bay reported that 2 minutes after the onset of the earthquake, a wave rose slowly and smoothly for a minute, then immediately withdrew to at least $6 \mathrm{~m}(20 \mathrm{ft})$ below sea level in a few seconds, exposing the bottom of Crab Bay and some parts of Sawmill Bay. The exact tide level in Sawmill Bay at the time of the earthquake is uncertain, but in the nearby communities, such as Seward and Whittier, the water was near the Mean Lower Low Water (MLLW) level (Kachadoorian, 1965; Lemke, 1967). We can assume approximately the same water level just prior to the earthquake in Sawmill Bay. Within a few moments after the withdrawal, the sea violently rushed back to at most $3 \mathrm{~m}(10 \mathrm{ft})$ above the extreme high-tide level along segments of the uplifted shore. All this happened before the shaking ceased. There were no other 'strange' waves, but erratic small surges continued through the night. The highest occurred at about 1:00 am, when the water almost reached the now-tectonically-uplifted extreme high-tide level.

Numerous local waves caused shoreline damage in nearby locations along Elrington and Latouche passages adjacent to Sawmill Bay. At several places, the runup was higher and more violent than in Sawmill Bay. Figure 2 shows the observed runup distribution in the Sawmill Bay vicinity. At the original location of the village on the tip of Chenega Island (shown on the inset map by a red rectangle with a flag) a similar sequence of events unfolded. Refer to Plafker and others (1969) and Nicolsky and others (2012) for a description of the tsunami at that location.
The origin of the destructive waves in various parts of Sawmill Bay as well as in Elrington and Latouche passages is unknown. The timing of the events suggest that these waves were of local origin, and may have been caused by submarine landslides. According to fathometer profiles of the area offshore from Chenega Island - offshore of the original village - no significant depth changes have been found at a depth of less than $180 \mathrm{~m}(590 \mathrm{ft})$, providing no evidence for a landslide-generated tsunami. A possible alternative explanation of the local waves observed in the southwestern part of Prince William Sound is provided by Plafker and others (1969); they inferred that these waves were generated by the horizontal displacement of the entire area in the southeast direction by $15-20 \mathrm{~m}(50-65 \mathrm{ft})$. The initial observed rise of the wave at Sawmill Bay is consistent with this alternative explanation.

\section{LANDSLIDE-GENERATED TSUNAMI HAZARD IN SAWMILL BAY}

Kulikov and others (1998) analyzed tsunami catalog data for the north Pacific coast and show that both south-central and southeastern Alaska have a long recorded history of tsunamis generated by submarine and subaerial landslides, avalanches, and rockfalls. In the majority of cases, tectonic tsunamis arriving in bays and fjords from the open ocean had wave heights smaller than those of local landslide-generated tsunamis. For example, the 1964 landslide-generated tsunami in Port Valdez devastated the waterfront and caused the 51 $\mathrm{m}(170 \mathrm{ft})$ runup near Shoup Bay, while the tectonic tsunami was not even noticed until a high tide late in the evening (Coulter and Migliaccio, 1966).

A primary reason for submarine slumps or landslides is the accumulation of sediments on underwater slopes and the consequent over-steepening of these unconsolidated deposits. Typical locations of unstable sediment accumulations are on steep underwater slopes at the mouths of glacial rivers, creeks, and streams. There are no known large masses of unconsolidated deposits along the shores of Sawmill Bay (Plafker and others, 1969). Moreover, the lack of large drainages, and a thin layer of sediment on Evans Island, suggest that local submarine-landslide-generated tsunamis are not the primary tsunami hazard for the community of Chenega Bay.

Far-field sources of potential submarine mass failures, which may generate waves in Sawmill Bay, are shown on figure 4 and include slides in the center of Prince William Sound as well as continental slope failures (Peter Haeussler, USGS, oral commun., 2012). Unfortunately, little is known about the extent, volume, and locations of these potential submarine landslides. Although sensitivity analyses of these landslides are feasible, the computed tsunami-inundation lines would be speculative, because extensive scientific research is required to constrain locations and volumes of these landslides to provide a credible scenario. Development of credible submarine-landslide-generated tsunamis in Sawmill Bay may be the focus of future reports for this community if more detailed information becomes available.

The destructive effects of mass-movement-generated tsunamis have been identified previously in south-central and 


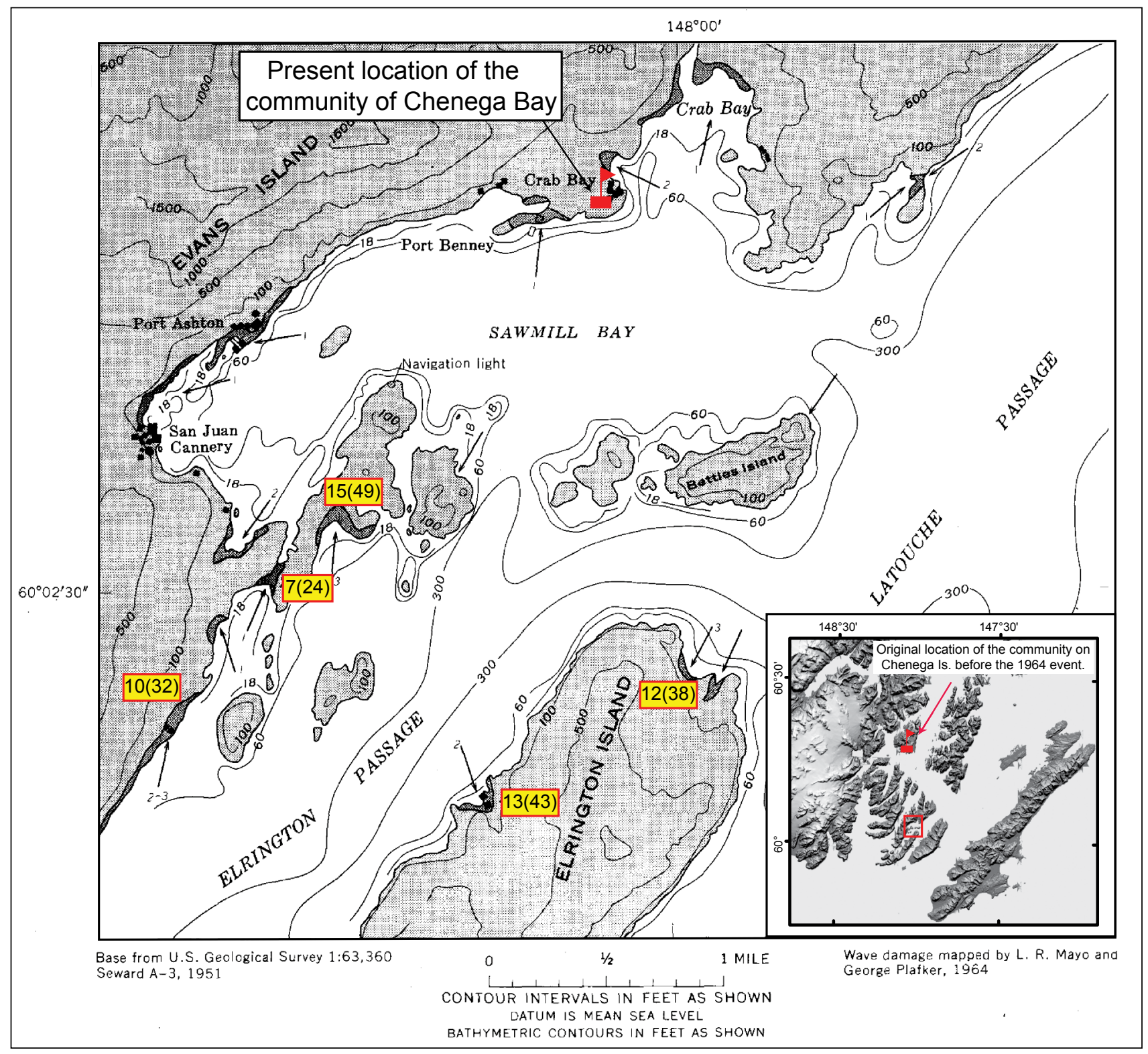

Figure 2. Distribution and intensity of wave damage in Sawmill Bay and Elrington and Latouche passages. Wave damage mapped by Plafker and others (1969). Yellow boxed numerals onshore next to shaded areas provide runup height in meters (feet) above sea level at the time of the earthquake. Wave runup direction is shown by an arrow. Relative magnitude of damage is indicated by a numeral at the foot of an arrow, based on the scale: 1-runup about 1-2 m (3-6 ft), 2-maximum

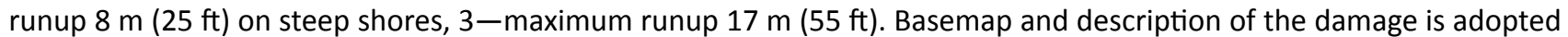
from Plafker and others (1969). Inset shows the relative position of the previous location of the community on Chenega Island with respect to Sawmill Bay; the red rectangle shows an outline of the base map.

southeastern Alaska. The best known and largest subaerial mass-movement-generated tsunami of historic time occurred in Lituya Bay, Alaska, on June 9, 1958, when a magnitude 7.8 earthquake on the nearby Fairweather fault produced an estimated 30 million $\mathrm{m}^{3}\left(1,050\right.$ million $\left.\mathrm{ft}^{3}\right)$ rockfall that rapidly entered the water and initiated a tsunami with the highest wave ever recorded (524 m [1,720 ft]) (Miller, 1960).

In light of recent field observations in a steep-walled glacial fjord, we appended the tsunami modeling and mapping report for the city of Whittier and western Passage Canal with an additional hypothetical rockfall-generated tsunami scenario (Nicolsky and others, 2011b; 2011c). Likewise, steep mountain slopes are present near the community of Chenega Bay, the southern side of Evans Island, and the northern tip of Elrington Island. Thus, the threat of avalanches, debris flows, and rock falls plunging into the ocean and consequently generating a tsunami, exists at the community. Our ability to accurately model effects of a potential rapid subaerial mass failure and the subsequent impact on the community of the rockfall/landslide/avalanche-generated tsunami depends on our knowledge of the type and geometry of the mass movement, local bedrock geology, and location. 


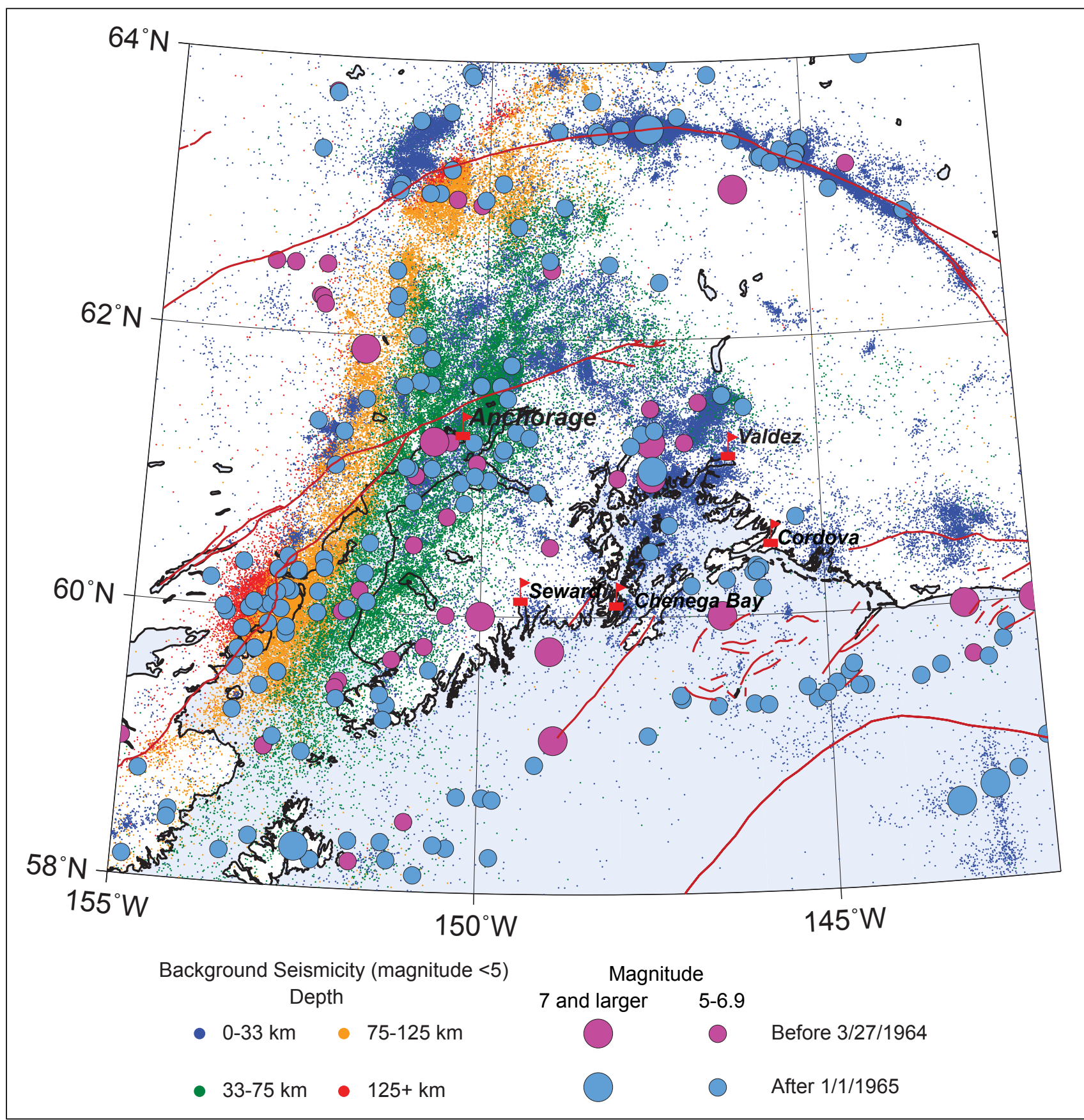

Figure 3. Earthquakes in south-central Alaska, from the Alaska Earthquake Center (AEC) catalog. Small dots correspond to earthquakes with magnitude less than 5 , with depth coded by color. Medium circles show significant earthquakes (magnitude 5 and greater) and large circles show powerful earthquakes before (magenta) and after (medium blue) the Great Alaska Earthquake of March 27, 1964. The main shock and aftershocks of that event are not included in the plot. Red lines delineate the major faults in the south-central Alaska.

Unfortunately, dense vegetation covers the slopes on which the potential mass failures may be located; as a result, the location and geometry of a potential mass movement that may threaten the community of Chenega Bay are unknown. Although some numerical simulations of the rockfall/landslide/ avalanche-generated tsunamis are possible, more research is necessary to constrain the mass movement sources before meaningful results can be generated.

In this report, we do not model tsunamis generated by any mass failures because there is insufficient data on the locations and volumes of these potential hazards. ${ }^{4}$

${ }^{4}$ Guidelines and best practices for tsunami inundation modeling for evacuation planning state that the modeling should add value to mapping products (National Tsunami Hazard Mapping Program [NTHMP], 2010). 


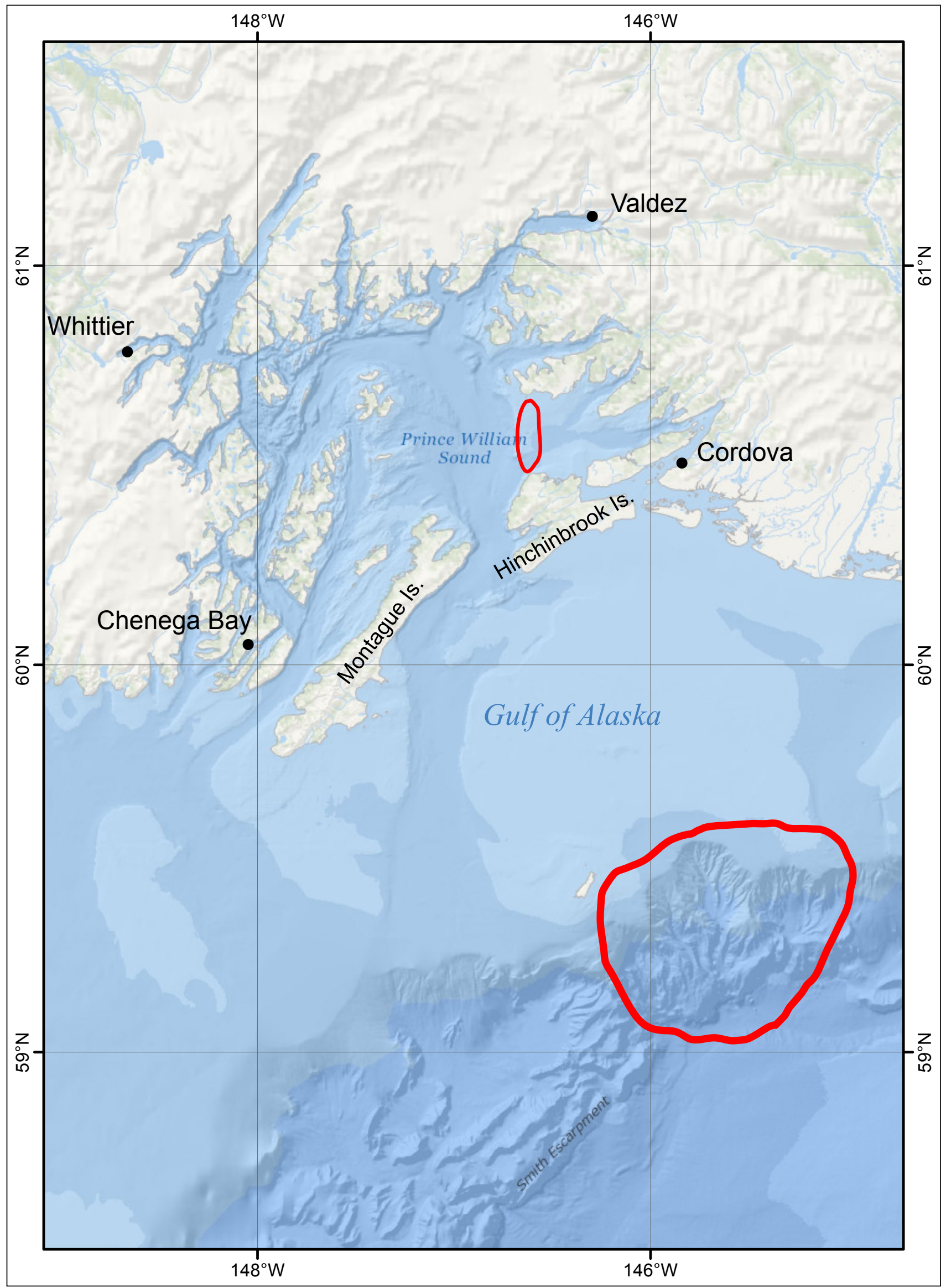

Figure 4. Locations of submarine slides (circled in red) in southern Prince William Sound and Gulf of Alaska, reported by Haeussler (oral commun., 2012). 


\section{METHODOLOGY AND DATA}

\section{GRID DEVELOPMENT AND DATA SOURCES}

One of the challenges in tsunami modeling is that the governing equations for water dynamics are continuous. In this work, we discretize the shallow-water equations in spherical coordinates on an Arakawa C-grid using a finite difference method. To resolve a wave, the grid must be fine enough, with at least four points per wavelength (Titov and Synolakis, 1995); however, more points than that are often necessary to achieve satisfactory accuracy (for example, Titov and Synolakis, 1997). To compute a detailed map of potential tsunami inundation triggered by local and distant earthquakes, we employ a series of nested computational grids. A nested grid allows for higher resolution in areas where it is needed, without expending computer resources in areas where it is not. The bathymetric and topographic relief in each nested grid is based on digital elevation models (DEMs) developed at the National Geophysical Data Center (NGDC), National Oceanic \& Atmospheric Administration (NOAA), in Boulder, Colorado. The extent of each grid used for Sawmill Bay mapping is shown in figure 5 and listed in table 1 . The coarsest grid, whose resolution is 2 -arc-minute, or approximately $2 \mathrm{~km}$, spans the central and northern Pacific Ocean, while the highest-resolution grid covers Sawmill and Crab bays and parts of Latouche and Elrington passages. The spatial resolution of the high-resolution grid satisfies NOAA minimum recommended requirements for computation of tsunami inundation (National Tsunami Hazard Mapping Program [NTHMP], 2010).

The bathymetric data for the 2-arc-minute resolution grid is extracted from the ETOPO2 dataset (National Geophysical Data Center). To develop 8/3-, 8- and 24-arc-second resolution grids, shoreline, bathymetric, and topographic digital datasets were obtained from several U.S. federal and academic agencies, including: NOAA's National Ocean Service (NOS), Office of Coast Survey, and NGDC; the U.S. Fish \& Wildlife Service (FWS); the U.S. Geological Survey
(USGS); and the U.S. Army Corps of Engineers (USACE). All data were shifted to World Geodetic System 1984 (WGS 84) horizontal and Mean Higher High Water (MHHW) vertical datums. The FWS statewide Alaska digital coastline was used to create a coastline of the Prince William Sound region. Bathymetric datasets used in the compilation of the Prince William Sound DEMs included NOS hydrographic surveys, a recent USACE harbor survey, NOAA Electronic Navigational Charts, multibeam swath sonar surveys, and NGDC trackline surveys. Topographic datasets of Prince William Sound were obtained from the USGS National Elevation Dataset 2-arc-second gridded topography and 1-arc-second NASA Space Shuttle Radar Topography. The data sources and methodology used to develop high-resolution, 8/3-, 8-, and 24-arc-second DEMs are described in detail in Caldwell and others (2009) and Lim and others (2009).

Accuracy of the high-resolution DEM developed by NOAA was determined by the topographic datasets with vertical accuracy of 10-15 m (33-50 ft) (Caldwell and others, 2009). The DEMs can have large vertical errors near the shoreline, which can cause uncertainties in the prediction of potential tsunami inundation. Hence, the topographic datasets were augmented with a real-time kinematic (RTK) GPS survey in the harbor area and along near-shore areas near Sawmill and Crab bays. The survey was conducted November 3-5, 2010, and locations of the GPS measurements are shown in figure 6 . The collected GPS measurements had $0.03-0.05 \mathrm{~m}(1.2-2$ in) horizontal and vertical accuracy with respect to the base station (Leica Geosystems AG, 2002). To achieve sub-meter accuracy of all GPS measurements with respect to the MHHW datum, it is ideal to set the base station up over a well-documented benchmark or monument that is referenced to MHHW. We could not find a conveniently located benchmark in Chenega Bay during the survey, and hence we used the following technique to convert the collected GPS measurements into the MHHW datum (fig. 7).

During the survey, at some partially enclosed locations, for instance in the harbor, where the water was relatively still, we took GPS measurements of the sea surface height, shown

Table 1. Nested grids used to compute propagation of tsunamis generated in the Gulf of Alaska to the community of Chenega Bay. The high-resolution grid is used to compute the inundation. Note that the grid resolution in meters is not uniform and is used to illustrate grid fineness near Sawmill Bay. The first dimension is the longitudinal grid resolution, while the second is the latitudinal grid resolution.

\begin{tabular}{|c|c|c|c|c|}
\hline \multirow{2}{*}{ Grid name } & \multicolumn{2}{|c|}{ Resolution } & \multirow{2}{*}{$\begin{array}{l}\text { West-East } \\
\text { boundaries }\end{array}$} & \multirow{2}{*}{$\begin{array}{l}\text { South-North } \\
\text { boundaries }\end{array}$} \\
\hline & arc-seconds & meters (in PWS) & & \\
\hline Level 0, Northern Pacific & $120 \times 120$ & $\approx 1,850 \times 3,700$ & $120^{\circ} 00^{\prime} \mathrm{E}-100^{\circ} 00^{\prime} \mathrm{W}$ & $10^{\circ} 00^{\prime} \mathrm{N}-65^{\circ} 00^{\prime} \mathrm{N}$ \\
\hline Level 1, Kodiak-Kenai & $24 \times 24$ & $\approx 370 \times 740$ & $145^{\circ} 00^{\prime} \mathrm{W}-156^{\circ} 00^{\prime} \mathrm{W}$ & $55^{\circ} 00^{\prime} \mathrm{N}-62^{\circ} 00^{\prime} \mathrm{N}$ \\
\hline Level 2, Coarse PWS & $8 \times 8$ & $\approx 120 \times 245$ & $145^{\circ} 00^{\prime} \mathrm{W}-150^{\circ} 00^{\prime} \mathrm{W}$ & $58^{\circ} 30^{\prime} \mathrm{N}-61^{\circ} 30^{\prime} \mathrm{N}$ \\
\hline Level 3, Fine PWS & $8 / 3 \times 8 / 3$ & $\approx 40 \times 82$ & $145^{\circ} 20^{\prime} \mathrm{W}-148^{\circ} 46^{\prime} \mathrm{W}$ & $59^{\circ} 40^{\prime} \mathrm{N}-61^{\circ} 20^{\prime} \mathrm{N}$ \\
\hline Level 4, High resolution & $8 / 9 \times 8 / 15$ & $\approx 14 \times 16$ & $147^{\circ} 57^{\prime} \mathrm{W}-148^{\circ} 07^{\prime} \mathrm{W}$ & $60^{\circ} 01^{\prime} \mathrm{N}-60^{\circ} 08^{\prime} \mathrm{N}$ \\
\hline
\end{tabular}




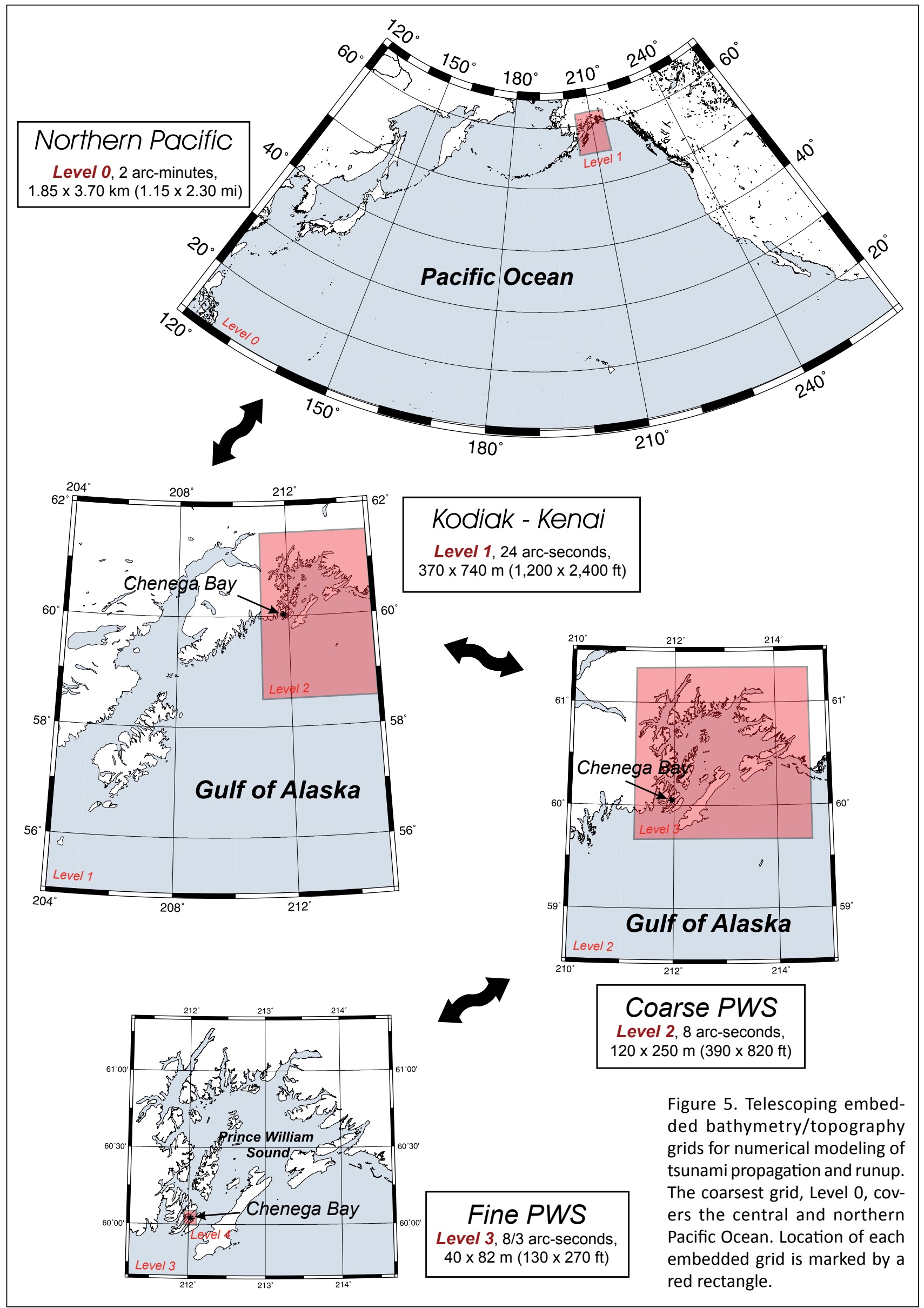




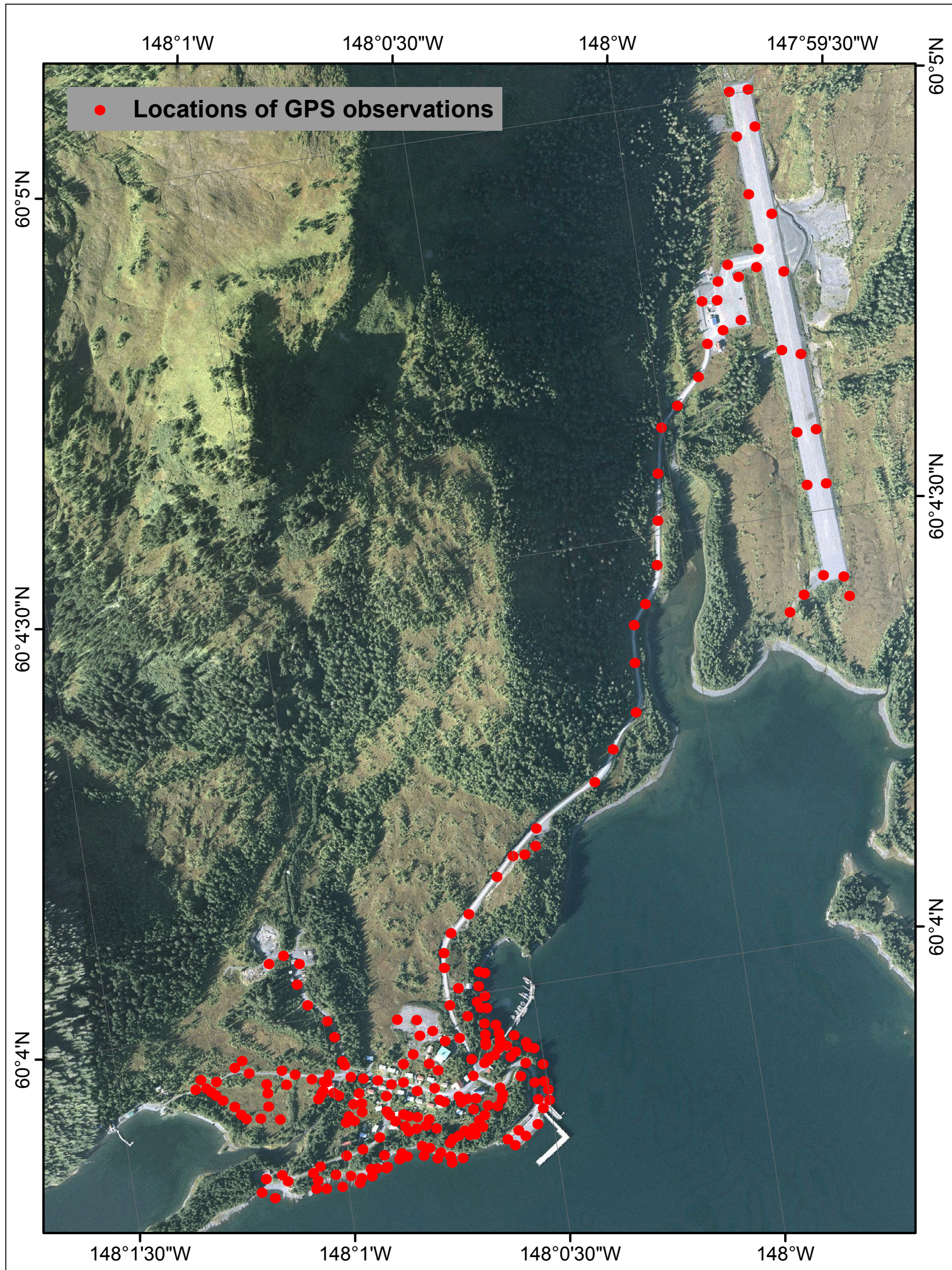

Figure 6. Locations of real-time kinematic (RTK) GPS measurements around the community and airport. 
A

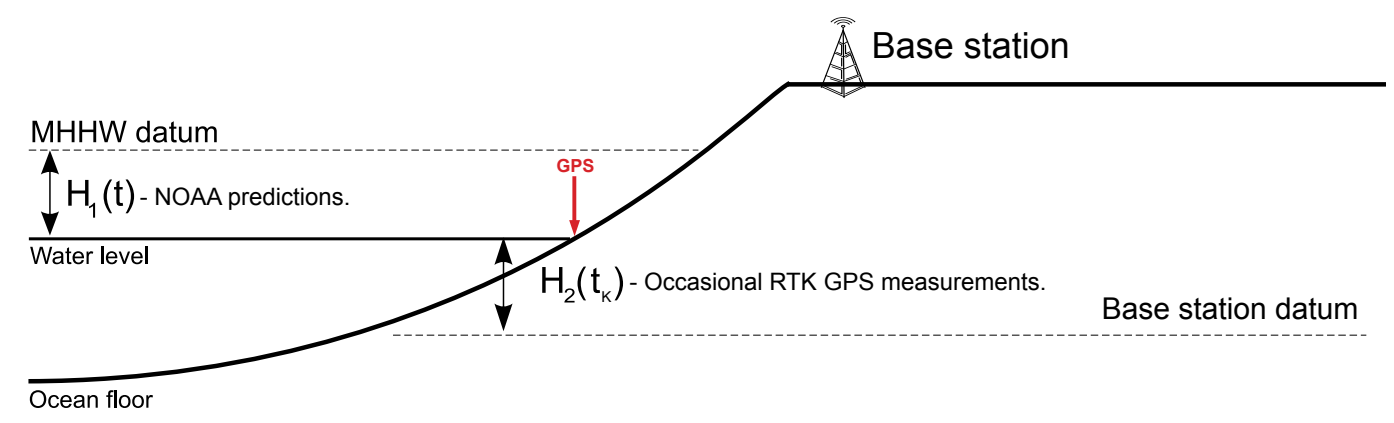

B

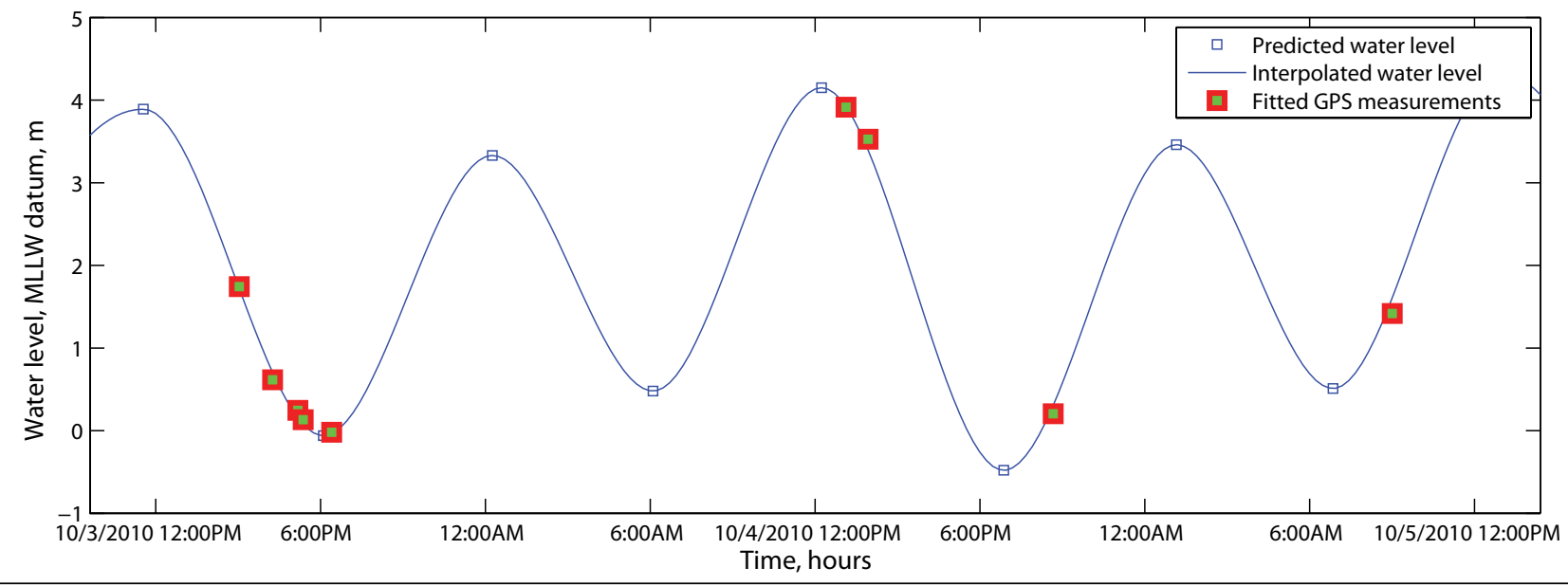

Figure 7. A. Schematic diagram showing the measurement of sea level in the WGS84 datum and the relation of the WGS84 datum to the MHHW datum. B. Predicted water-level dynamics in Sawmill Bay (http://tidesandcurrents.noaa.gov/) and the fitted GPS measurements of the water level in the MHHW datum.

by the red arrow in figure 7a. Sea level was measured at low and high tides as well as at some intermediate tide stages. All RTK GPS measurements have an accuracy of several centimeters relative to the base station datum. Hence, the measured tide level, denoted by $\mathrm{H}_{2}$, is known with respect to the base station datum at some instances of time, $t_{\mathrm{k}}$, with an accuracy of several centimeters. Here, $\mathrm{k}$ stands for the index number of the sea level measurement.

Given the tide level, $\mathrm{H}_{1}(\mathrm{t})$, with respect to the MLLW datum (predictions by NOAA, http://tidesandcurrents.noaa. gov/), we calculated the vertical shift between the MLLW datum and the base station datum by finding the difference (in the least square) between the GPS-measured sea level, $\mathrm{H}_{2}$, and the NOAA-observed sea level, $\mathrm{H}_{1}$, at the instances $t_{\mathrm{k}}$. The results of the least-square fitting for Sawmill Bay are shown in figure $7 \mathrm{~b}$. We then apply the same shift to all collected GPS measurements, and thus convert the entire survey to the MLLW datum.
We emphasize that the accuracy of converting the survey to the MLLW datum depends on the accuracy of NOAA's Tides and Currents model prediction. Comparison of the tide data at Cordova and Seward with the corresponding NOAA prediction shows that the deviation is less than $0.6 \mathrm{~m}$ ( $2 \mathrm{ft})$. The largest discrepancy on November 4, 2010,

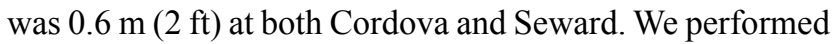
our modeling under the assumption that the error between the actual and predicted tides is approximately the same in Sawmill Bay. Hence, we estimate that the error of converting the observations to the MLLW datum does not exceed $1 \mathrm{~m}(3.3 \mathrm{ft})$ in flat-lying areas where no abrupt topographic changes exist. Finally, we note that the collected GPS measurements are recorded in WGS84 horizontal datum, with the horizontal accuracy of approximately 3-5 m (10-16 ft) (Leica Geosystems AG, 2002). The converted GPS survey has been supplied to the NGDC, where the high-resolution DEM of Chenega Bay with the MHHW vertical datum was developed (National Geophysical Data Center/World Data Center, http://www.ngdc.noaa.gov/hazard/tsu db.shtml). 


\section{NUMERICAL MODEL OF TSUNAMI PROPAGATION AND RUNUP}

NOAA recently published a technical memorandum that outlines major requirements for numerical models used in inundation mapping and tsunami forecasting, and describes a procedure for model evaluation (Synolakis and others, 2007; NTHMP, 2012). There are two major components to this process. The first is model validation, which ensures that the model correctly solves appropriate equations of motion by comparing model results with known solutions. This is achieved through analytical and laboratory benchmarking. The second component is model verification, or testing the model, using observations of real events through field-data benchmarking.

The numerical model currently used by the Alaska Earthquake Center (AEC) for tsunami-inundation mapping has been validated through a set of analytical benchmarks and tested against laboratory and field data (Nicolsky and others, 2011a; Nicolsky, 2012). The model solves nonlinear shallow-water equations using a finite-difference method on a staggered grid. For any coarse-fine pair of computational grids, we apply a time-explicit numerical scheme as follows. First, we compute the water flux inside a coarse-resolution grid. These calculated flux values are used to define the water flux on a boundary of the fine-resolution grid. Next, the water level and then the water flux are calculated over the fine-resolution grid. Finally, the water level computed in the fine-resolution grid is used to define the water level inside the area of the coarse-resolution grid that coincides with the fine grid. Consecutively, we compute the water elevation for all other points in the coarse grid and proceed to the next time step. More details about the numerical scheme, grid nesting and time stepping can be found in Goto and others (1997) and Nicolsky and others (2011a). Despite the fact that nested grids decrease the total number of grid cells needed to preserve computational accuracy within certain regions of interest, actual simulations are still unrealistic if parallel computing is not implemented. Our modeling utilized the Portable Extensible Toolkit for Scientific computation (PETSc), which provides sets of tools for the parallel numerical solution of shallow-water equations (Balay and others, 2004). In particular, each computational grid listed in table 1 can be subdivided among an arbitrary number of processors. The above-mentioned passing of information between the water flux and level is implemented efficiently using PETSc subroutines.

We assess hazards related to tectonic tsunamis in Sawmill Bay by performing model simulations for each hypothetical earthquake source scenario. To simulate tsunami dynamics caused by a seafloor deformation from an earthquake, we introduce some simplifications. First, the finite speed of the rupture propagation along the fault is not taken into account. Second, the initial topography is modified to account for coseismic deformation of land due to the earthquake (Nicolsky and others, 2012).

At the end of a tsunami simulation, each of the grid points has a value of either 0 if no inundation occurs, or 1 if seawater reaches the grid point at any time. The inundation line lies halfway between grid points with values of 0 and 1 , but was adjusted visually to accommodate obstacles or local variations in topography not represented by the DEM. Although the developed algorithm has passed through rigorous benchmarking procedures (Nicolsky and others, 2011a; Nicolsky, 2012), there is still an uncertainty in locating the inundation line that is inherent in the process but not quantifiable. Some factors that can affect the accuracy of the modeled inundation line include the suitability of the earthquake source model, accuracy of the bathymetric and topographic data, and the adequacy of the numerical model in representing the generation, propagation, and runup of tsunamis. In this report, we do not attempt to adjust the modeled inundation limits to account for these uncertainties.

We note several limitations of the model. One important consideration is that the model does not take into account the periodic change of sea level caused by tides. For the purpose of modeling the worst-case scenario, we conducted all model runs using bathymetric data that correspond to the MHHW tide level in Sawmill Bay, with the exception of numerical modeling of the 1964 tsunami.

\section{MODELS OF TSUNAMI GENERATION}

Currently, there are two methods to model generation of a tsunami. The first method is called a passive generation approach, in which the tsunami generation process is modeled by specifying initial conditions (Kervella and others, 2007). An example of the passive generation model is the well-known piston model, in which the initial water surface displacement is equal to the vertical seafloor displacement, while the initial water velocity is set to zero (Kajiura, 1970). Horizontal displacements are excluded from this tsunami generation model. Berg and others (1970) argued that in the 1964 event the contribution to the potential energy from horizontal displacement was negligible when compared to the contribution from the vertical displacement, further diminishing the importance of incorporating the horizontal displacements into the model. More recent studies by Tanioka and Satake (1996), Song and others (2008), and Nagao and others (2010), however, suggest the need to reconsider the importance of horizontal displacement in tsunami generation. Suleimani (2011) studied the contribution of the horizontal displacements to the modeled tsunami dynamics from the 1964 event, and found that numerical predictions of the water level near Kodiak Island are sensitive to the inclusion of horizontal displacements into the tsunami generation process.

In contrast to the passive approach, an active approach takes into account not only the vertical displacement, but the entire dynamics of the seafloor during the earthquake. The active approach of modeling tsunami generation away from the shoreline has been extensively studied by Pelinovsky (1982), Dotsenko and Soloviev (1990), and Pelinovsky (1996) and in references they cite. At the same time, Voit (1987) noted the importance of the active approach by considering generation and propagation of the 1960 Chilean tsunami. In the framework of linear shallow-water theory, Dutykh and others (2006) and Levin and Nosov (2008) showed that if seafloor 
motion is considered, the tsunami generated differs from one generated by the piston model. Additionally, a laboratory study by Iwasaki (1982) suggested that if the gradient of slope of the ocean bottom is greater than $1 / 3$ (18 degrees), the role of the horizontal displacement in the tsunami generation cannot be considered insignificant.

Plafker and others (1969) conducted geologic investigations after the 1964 earthquake in numerous locations around south-central and southeastern Alaska. From these studies, it was concluded that a primary cause of local waves of 'unknown origin' was fast horizontal displacement. According to the re-triangulation data, the southward land displacement increases from approximately $6 \mathrm{~m}(20 \mathrm{ft})$ near Whittier in the northern part of the sound to as much as $19.5 \mathrm{~m}(64 \mathrm{ft})$ near Evans and Latouche islands in the south Plafker (1969). According to Wilson and Tørum (1972, p. 461) and references they cited, the maximum velocity of earth movement might have been about $1.5 \mathrm{~m} / \mathrm{s}(5 \mathrm{ft} / \mathrm{s})$. It was inferred by Plafker and others (1969) that the major factors contributing to the formation of seiche-type tsunamis are the magnitude of the tectonic displacement as well as the orientation and configuration of the shoreline. Thus, abrupt changes in the bathymetry offshore, as well as large horizontal displacements related to potential earthquakes, both contribute to tsunami hazard in Chenega Bay.
In this report, we include the horizontal tectonic displacement in the tsunami generation process. We emphasize that ignoring the horizontal tectonic displacements during the 1964 event does not yield satisfactory modeling results of the tsunami runup at the original location of the village on Chenega Island. Refer to Nicolsky and others (2012) for detailed description of the numerical model of the tsunami generation and simulation of the 1964 tsunami runup around Chenega Island.

\section{TSUNAMI SOURCES}

The 1964 earthquake triggered some of the most destructive tsunamis in Alaska's history. Before discussing this earthquake as well as other credible scenarios for potential tsunamigenic earthquakes, we review some aspects of the regional plate tectonics.

\section{REGIONAL SEISMOTECTONICS}

According to the segmentation model of Nishenko and Jacob (1990), south-central Alaska includes three segments of the megathrust: the Yakataga-Yakutat (YY), Prince William Sound (PWS), and Kodiak Island (KI) segments (fig. 8). Using seismic waveform data, Christensen and Beck (1994) show that there were two areas of high moment release

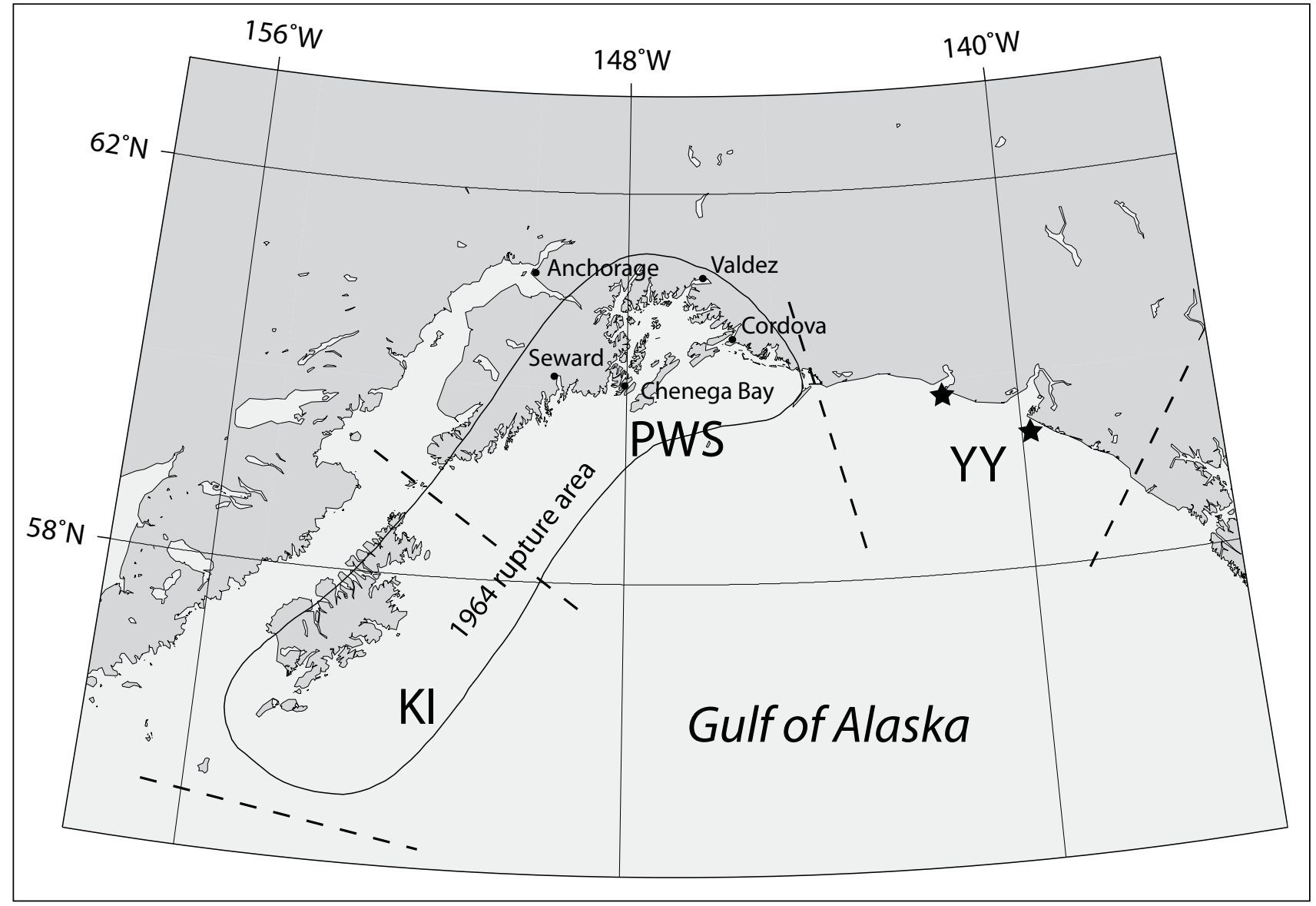

Figure 8. Map of south-central Alaska, showing the rupture zone of the 1964 Great Alaska Earthquake and divisions of the Alaska-Aleutian megathrust: the Prince William Sound (PWS), Kodiak Island (KI), and Yakataga-Yakutat (YY) segments. Stars indicate epicenters of two September 1899 earthquakes. 
representing the two major asperities of the 1964 rupture zone: the Prince William Sound asperity with an average slip of $18 \mathrm{~m}(59 \mathrm{ft})$ and the Kodiak asperity with an average slip of $10 \mathrm{~m}(33 \mathrm{ft})$. Analysis of historical earthquake data in the PWS and KI segments (Nishenko and Jacob, 1990) showed that the KI segment produced significant megathrust earthquakes more frequently than, and also independently of, the PWS segment. Paleoseismic data also show that the KI segment ruptured independently in a large earthquake about 500 years ago (Gilpin, 1995), about 360 years more recently than the penultimate great earthquake that ruptured both the KI and PWS segments (Carver and Plafker, 2008).

The results of joint inversion of tsunami and geodetic data from the 1964 earthquake (Johnson and others, 1996) also suggest the division of the rupture zone into two different segments. These segments have different recurrence intervals, with estimates of the recurrence interval for $M_{S} 7.5-8$ earthquakes in the KI segment being as low as 60 years (Nishenko, 1991 [as cited in Johnson and others, 1996]). On the basis of all published paleoseismic data for the region, Carver and Plafker (2008) calculated that the median intervals between the past eight great earthquakes $M_{w}>8$ in the PWS segment of the Aleutian megathrust range from 333 to 875 years, with an average of 589 years.

The YY segment at the eastern end of the megathrust is a complex collision zone where the Yakutat microplate moves northwest toward central Alaska (Carver and Plafker, 2008; Freymueller and others, 2008). This segment translates predominantly strike-slip motion on its eastern side to shallow-dipping subduction on its west side (Nishenko and Jacob, 1990). The southern and eastern boundaries of the Yakutat microplate are well defined, but a collection of distributed fold and thrust zones, splay faults, and mountainbuilding regions complicates the northern and western edges of the microplate. We note that the interaction between the Yakutat microplate and the Pacific and North American plates is complex and poorly understood. Plafker and Thatcher (2008) re-evaluated the mechanisms of the two great Yakutat Bay earthquakes of September 1899 (epicenters shown in fig. 8) and showed that coseismic deformation was onshore uplift, explaining the absence of a tsunami in the Gulf of Alaska. Plafker and Thatcher (2008) concluded that the 1899 earthquake sequence most likely did not rupture through the offshore portion of the Yakataga seismic gap, a region between the 1964 rupture area and the focal area of the 1899 earthquakes. This finding suggests that the YY segment has a high potential for a future tsunamigenic earthquake.

In a paleoseismic study of regional land subsidence at Kenai Peninsula sites, Hamilton and Shennan (2005) estimated coseismic subsidence during the 1964 earthquake and two earlier events. It was shown that an earthquake dated to 1,500-1,400 years BP produced more than twice the subsidence caused by the 1964 earthquake. By comparing the Kenai Peninsula sites with other sites around Cook Inlet, the authors found that each of the three great earthquakes in the study had a different pattern of coseismic subsidence. Shennan and others (2008) present geologic evidence of six prehistoric major tsunamigenic earthquakes in the Kenai Peninsula area of south-central Alaska in the past 4,000 years based on radiocarbon ages of tidal marsh deposits in Girdwood. The results of this study indicate variable recurrence intervals and both similarities and differences in temporal and spatial patterns over multiple earthquake cycles. Recent work by Shennan and others (2009) tests the hypothesis that in some seismic cycles, megathrust segments can, as proposed in the segmentation model by Nishenko and Jacob (1990), rupture simultaneously to produce earthquakes greater than historical events. Based on paleoseismic data, Shennan and others (2009) determined that earthquakes approximately 900 and 1,500 years BP simultaneously ruptured three adjacent segments of the Aleutian megathrust: the PWS and KI segments, as well as the YY segment. The rupture area of these earthquakes was estimated to be $23,000 \mathrm{~km}^{2}\left(9,000 \mathrm{mi}^{2}\right)$ greater than that of the $M_{w} 9.2$ Great Alaska Earthquake of 1964 , and with a 15 percent larger seismic moment. These studies demonstrate that an understanding of the historical great earthquakes in the area is insufficient for comprehensive tsunami hazard assessment in south-central Alaska and that detailed studies of multiple great earthquakes are required.

\section{TECTONIC TSUNAMI SOURCES}

The 1964 Great Alaska Earthquake ruptured the PWS and KI segments simultaneously (Christensen and Beck, 1994). Shennan and others (2009) presented geologic evidence that the PWS and KI segments as well as a portion of the Yakutat microplate could have ruptured simultaneously in the past. Therefore, we consider hypothetical tsunamigenic earthquakes produced by various combinations of the PWS, KI, and YY segment ruptures, some occurring simultaneously. We also considered a rupture of the Cascadia subduction zone, involving the Juan de Fuca plate underlying the Pacific Ocean from mid-Vancouver Island in British Columbia, southwestern Canada, along the Pacific Northwest coast. Additionally, we considered a Tohoku-type earthquake in the Gulf of Alaska region. A list of the hypothetical scenarios considered is provided in the table below.

\section{A. Models of the 1964 Great Alaska Earthquake}

The 1964 tsunami affected numerous communities along the Pacific Northwest coast, Hawaii, and Alaska. This tsunami was studied in depth by several investigators (Plafker and others, 1969; Wilson and Tørum, 1972). Plafker (1967) gave a detailed description of the motion on the Patton Bay fault during the earthquake and provided a full report of the surface rupture and fault motion, as well as several pieces of evidence suggesting that the fault continues on the ocean floor well past the region where it is currently mapped. Holdahl and Sauber (1994) applied Plafker's description to construct their model of the Patton Bay fault, which was used in an inversion of geodetic data. Johnson and others (1996) used the results of Holdahl and Sauber (1994) to augment their joint inversion of geodetic and tsunami data and to further reconstruct coseismic deformation models of the 1964 earthquake. 
Scenario 1. Repeat of the 1964 event: Source function based on coseismic deformation interpolated from data by Plafker (1969) and referred to as the Plafker Deformation Model (PDM).

Comparison of the ground level and geodetic observations before and after the 1964 event (for example, Parkin, 1966) revealed vertical and horizontal displacement at many locations along the coast of PWS and KI. The densest set of point-wise observations of these displacements were collected by G. Plafker and U.S. Geological Survey personnel inside the PWS region in 1964 and 1965 (Plafker, 1969).To assess the limitation of the existing data coverage in modeling the 1964 tsunami in Sawmill Bay, we drew contours of the Tsunami Travel Time (TTT) on top of the contours of the interpreted available data (fig. 9a). The data coverage restricts interpolation only to the PWS region, while the 1964 earthquake rupture zone extends much farther to the west and south. The yellow triangle marks the location of Sawmill Bay. The vertical displacement contours from Plafker and others (1969) are plotted by red lines. The 10- and 20-minute TTT contours are displayed by cyan and green lines, respectively. The TTT contours are constructed according to the Huygen's principle (Shokin and others, 1987), for the case of a pointwise tsunami source set in Sawmill Bay. According to the definition of the TTT contour, the N-minute TTT contour encompasses the region reached by the tsunami in less than $\mathrm{N}$ minutes from its source. Thus, inside the plotted 20-minute contour, a sea bottom deformation will produce a wave that travels to Sawmill Bay in less than 20 minutes, with waves generated outside the 20-minute contour arriving at Sawmill Bay more than 20 minutes after an onset of the earthquake.

We constructed an interpolation of the sea-level change observations assembled by Plafker and others (1969) in the PWS region. We emphasize that we interpolated existing observations of the vertical and horizontal displacements without extrapolating them beyond the data coverage region. We termed this interpolation of the coseismic observations the Plafker Deformation Model (PDM). Since the 20-minute TTT contour lies within the domain of the PDM, we conclude that the PDM allows for modeling the first 20 minutes of the tsunami dynamics in Sawmill Bay without any assumptions regarding the sea-floor deformation on the continental shelf in the Gulf of Alaska. Recall that the runup in Sawmill Bay occurred in the first 10 minutes after the 1964 earthquake, and hence the tsunami modeling with the PDM should reproduce the observations. The developed scenarios are summarized in table 2.

For other scenarios, we use two coseismic deformation models of the 1964 earthquake - the Johnson and others (1996) and the Suito and Freymueller (2009) models - to generate the vertical displacements of the sea floor during the earthquake. We hereafter reference Johnson and others (1996) as the Johnson deformation model (JDM) and Suito and Freymueller (2009) as the Suito deformation model (SDM).

Johnson and others (1996) derive a detailed slip distribution for the 1964 earthquake, which has eight subfaults representing the KI asperity and nine subfaults in the PWS asperity. One subfault was assigned to represent the Patton Bay fault. Johnson and others (1996) and Holdahl and Sauber (1994) used only the mapped extent of the fault, approximately $72 \mathrm{~km}$ (45 mi), despite evidence suggesting that the fault may extend much farther to the southwest. Suito and Freymueller (2009) found that they could not fit all the GPS data accurately unless they extended the fault past the tip of the Kenai Peninsula. In the same report, Suito and Freymueller (2009) developed a coseismic deformation model of the 1964 earthquake based on a three-dimensional (3-D) viscoelastic model, which implements a realistic geometry with an elastic slab having a low dip angle. This coseismic model is not based on an inversion, but it resembles a recently published inversion model (Ichinose and others, 2007) as well as some previously proposed models (Holdahl and Sauber, 1994; Johnson and others, 1996; Santini and others, 2003).

The main difference between JDM and SDM is that the latter incorporates slightly higher slip near the downdip end of the rupture to explain the horizontal displacements. Additionally, the rupture in the SDM is assumed to occur deeper than in the JDM. Consequently, the deeper subfaults in the SDM produce smoother variation of the sea-floor deformation than in the JDM. Both models introduce the Patton Bay splay fault to explain the large uplift at Montague Island. It is assumed in the JDM that the extent of this splay fault was not much larger than its subaerial outcrop on Montague Island. On the other hand, it is assumed in the SDM that the same fault extends much farther to the west than was previously assumed by Holdahl and Sauber (1994) and Johnson and others (1996). We note that although the Patton Bay fault slipped approximately $10 \mathrm{~m}(33 \mathrm{ft})$ at the southwestern tip of Montague Island, there has yet to be a comprehensive submarine survey to document the extent of that splay fault. Refer to the study by Liberty and others (2013) for additional details regarding the south-west extension of the splay fault system.

Scenario 2. Repeat of the 1964 event: Source function based on coseismic deformation model by Johnson and others (1996) (JDM)

The 1964 earthquake vertical coseismic displacement was modeled as rupture by eight subfaults representing the Kodiak asperity and nine subfaults in the Prince William Sound asperity. One subfault was assigned to represent the Patton Bay fault, although the contribution of this fault to the far-field tsunami waveform was negligible. The fault parameters required to compute sea-floor deformation are the epicenter location, area, dip, rake, strike, and amount of slip on the fault. We used the equations of Okada (1985) to calculate distribution of coseismic uplift and subsidence resulting from this slip distribution. This source function was previously applied to calculation of 1964 tsunami inundation in the Kodiak and Kachemak Bay communities (Suleimani and others, 2002, 2005; Nicolsky and others, 2011b, 2013). The vertical and horizontal ground/ocean floor displacements according to the JDM are shown in figure $9 \mathrm{~b}$. 
A

Scenario 1: Repeat of the 1964 event, PDM
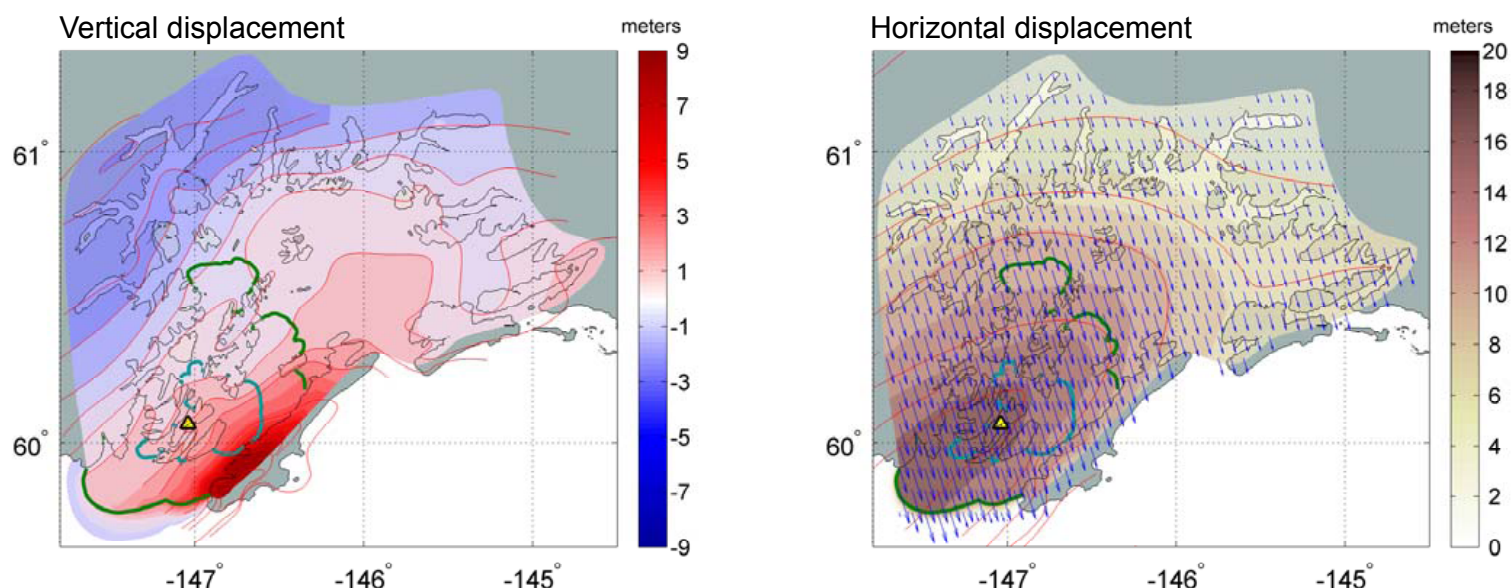

B

Scenario 2: Repeat of the 1964 event, JDM
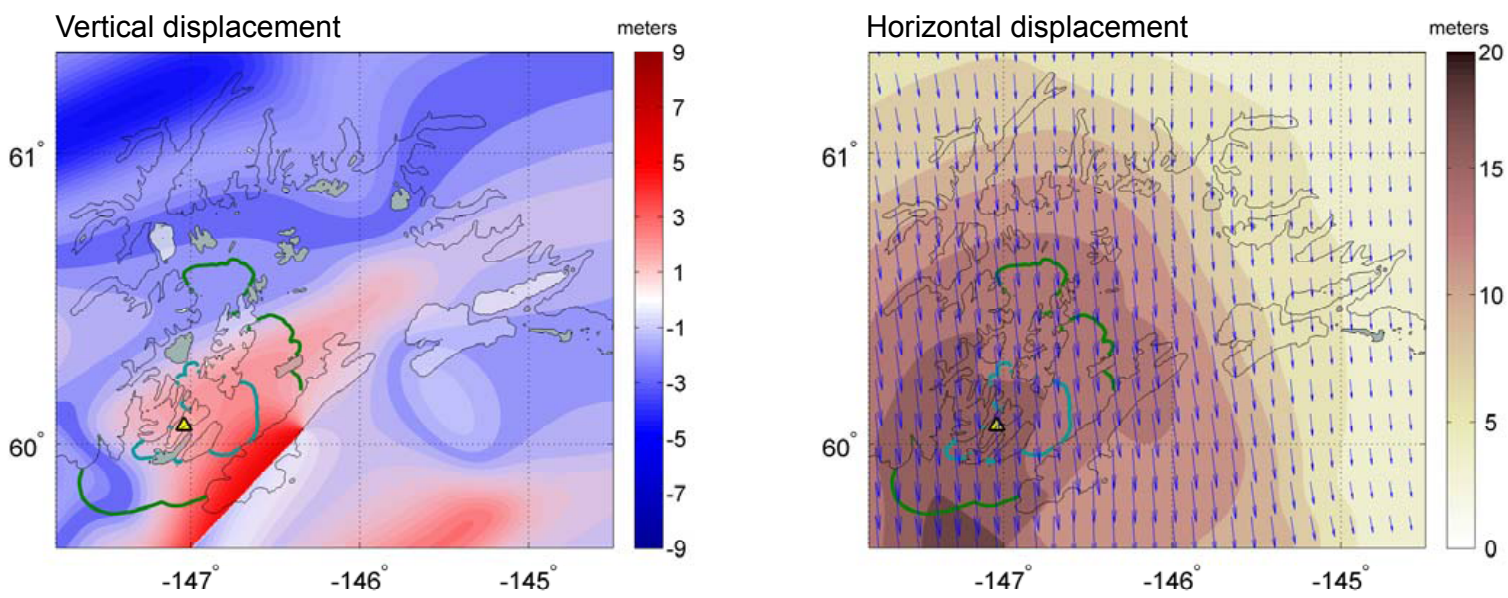

C

Scenario 3: Repeat of the 1964 event, SDM
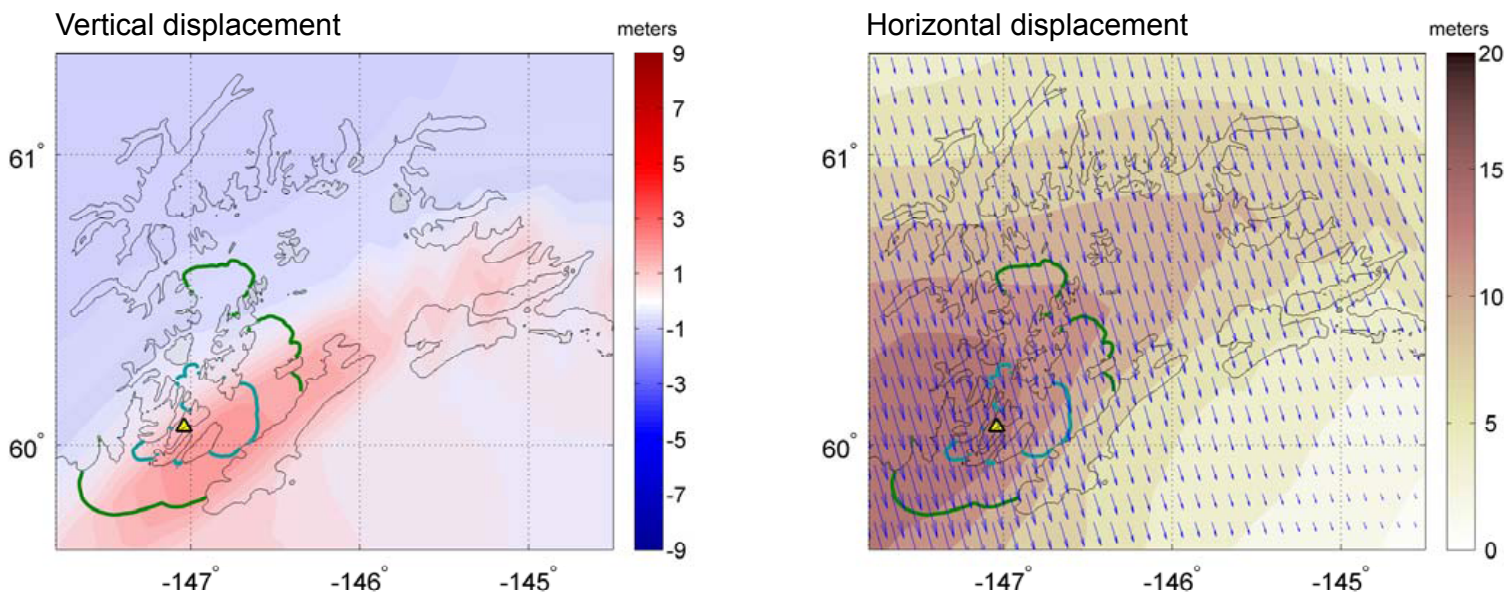

Figure 9. Vertical (left) and horizontal (right) displacements in the Prince William Sound region in scenarios 1-3. The yellow triangle marks the location of the community of Chenega Bay. In plot $A$, red lines mark the vertical and horizontal ground displacement contours as in Plafker (1969). In A, B, and C, cyan and green lines mark 10- and 20-minute Tsunami Travel Time (TTT) contours, respectively; hypothetical tsunami source is at Chenega. Purple arrows show directions of the horizontal ground displacement according to each scenario. 
Table 2. All hypothetical scenarios used to model tsunami runup in Sawmill Bay.

\begin{tabular}{|c|c|c|c|c|c|}
\hline \# & $\mathbf{M}_{\mathbf{w}}$ & Description & $\begin{array}{c}\text { Maximum } \\
\text { Slip, } \\
\text { meters (feet) }\end{array}$ & $\begin{array}{c}\text { Maximum } \\
\text { Subsidence, } \\
\text { meters (feet) }\end{array}$ & $\begin{array}{c}\text { Maximum } \\
\text { Uplift, } \\
\text { meters (feet) }\end{array}$ \\
\hline 1 & 9.2 & $\begin{array}{l}\text { Earthquake in the Gulf of Alaska region, } \\
\text { repeat of the } 1964 \text { event, PDM }\end{array}$ & unknown & $2.5(8.2)$ & $11.1(36.4)$ \\
\hline 2 & 9.2 & $\begin{array}{l}\text { Earthquake in the Gulf of Alaska region, } \\
\text { repeat of the } 1964 \text { event, JDM }\end{array}$ & $22.1(72.4)$ & $5.5(18.0)$ & $6.9(22.6)$ \\
\hline 3 & 9.2 & $\begin{array}{l}\text { Earthquake in the Gulf of Alaska region, } \\
\text { repeat of the } 1964 \text { event, SDM }\end{array}$ & $22.5(73.8)$ & $1.8(5.9)$ & $2.8(9.2)$ \\
\hline 4 & 9.3 & $\begin{array}{l}\text { Multi-segment earthquake based on the } \\
\text { JDM }\end{array}$ & $22.1(72.4)$ & $5.5(18.0)$ & $8.4(27.6)$ \\
\hline 5 & 9.3 & $\begin{array}{l}\text { Multi-segment earthquake based on the } \\
\text { SDM }\end{array}$ & $22.5(73.8)$ & $4.3(14.1)$ & $6.4(21.0)$ \\
\hline 6 & 8.7 & $\begin{array}{l}\text { Earthquake of the Yakutat-Yakataga } \\
\text { segment }\end{array}$ & $15.0(49.2)$ & $4.5(14.8)$ & $6.6(21.6)$ \\
\hline 7 & 8.7 & $\begin{array}{l}\text { Earthquake of the Kodiak Island asperity } \\
\text { of the JDM }\end{array}$ & $14.5(47.5)$ & $2.2(7.2)$ & $5.8(19.0)$ \\
\hline 8 & 8.7 & $\begin{array}{l}\text { Earthquake of the Kodiak Island asperity } \\
\text { of the SDM }\end{array}$ & $20.0(65.6)$ & $1.4(4.6)$ & $1.9(6.2)$ \\
\hline 9 & $\begin{array}{c}9.0- \\
9.1\end{array}$ & $\begin{array}{l}\text { Earthquake in the Cascadia subduction } \\
\text { zone }\end{array}$ & $36(118)$ & $7.5(24.6)$ & $10.9(35.8)$ \\
\hline 10 & 9.0 & $\begin{array}{l}\text { Earthquake in the Gulf of Alaska region: } \\
4-18 \mathrm{~km}(2.5-11.2 \mathrm{mi}) \text { depth }\end{array}$ & $58.1(190.5)$ & $8.0(26.2)$ & $13.5(44.3)$ \\
\hline
\end{tabular}

Scenario 3. Repeat of the 1964 event: Source function based on coseismic deformation model by Suito and Freymueller (2009) (SDM)

This coseismic deformation model of the 1964 earthquake is based on a 3-D viscoelastic model, incorporating a realistic geometry with an elastic slab having a low dip angle. Suito and Freymueller (2009) employed 3-D finite element method code GeoFEM by Okuda and others (2003) to compute the coseismic displacements and used previous inversion models along with the critical features of the observations. Consult Suito and Freymueller (2009) for further details regarding the computations of the coseismic displacements. The vertical and horizontal ground/ocean-floor displacements according to the SDM are shown in figure 9c.

\section{B. Models of a Multi-Segment Great Alaska Earthquake}

Geologic evidence in Shennan and others (2009) suggests the possibility that the Prince William Sound and Kodiak Island segments of the 1964 rupture area, as well as a portion of the Yakutat microplate, may rupture simultaneously. To evaluate whether this event would cause a damaging tsunami scenario for Chenega Bay, we constructed source functions of this multi-segment rupture using both the JDM and SDM. Additionally, we consider the possibility that the Yakutaga-Yakutat segment ruptures independently.

We apply the following constraints based on the hypothetical earthquake model of Shennan and others (2008).
The extended source function includes three segments of the Aleutian megathrust: the Prince William Sound (PWS), Kodiak Island (KI), and Yakataga-Yakutat (YY) segments. The total seismic moment is about 15 percent greater than that of the 1964 earthquake. The new source function produces coseismic vertical uplifts along the Gulf of Alaska coastline segment between the Copper River basin and Yakataga area, in order to match the coseismic deformation pattern to paleoseismic data (Shennan and others, 2009).

To construct a rupture model for the YY segment, we assume four subfaults whose parameters are listed in table 3 . We calculated coseismic deformations produced by this segment using Okada's algorithm (Okada, 1985), and then combined them with the 1964 coseismic deformations produced by either the JDM or the SDM.

Scenario 4. Multi-Segment JDM event: Source function based on extension of the JDM

The model in scenario 2 is extended by including a rupture model for the YY segment. The vertical coseismic deformation pattern for the extended 1964 rupture is shown in figure 10a.

Scenario 5. Multi-Segment SDM event: Source function based on extension of the SDM

The model in scenario 3 is extended by including a rupture model for the YY segment. The vertical coseismic deformation pattern for the extended 1964 rupture is shown in figure $10 \mathrm{~b}$. 
Table 3. Fault parameters for the Yakataga-Yakutat (YY) segment

\begin{tabular}{|c|c|c|c|c|c|c|c|c|}
\hline $\begin{array}{c}\text { Latitude } \\
\text { (deg. N) }\end{array}$ & $\begin{array}{c}\text { Longitude } \\
(\mathbf{d e g} . \mathbf{W})\end{array}$ & $\begin{array}{c}\text { Depth } \\
\mathbf{( k m )}\end{array}$ & $\begin{array}{c}\text { Length } \\
\mathbf{( k m )}\end{array}$ & $\begin{array}{c}\text { Width } \\
\mathbf{( k m )}\end{array}$ & $\begin{array}{c}\text { Strike } \\
\mathbf{( d e g .})\end{array}$ & $\begin{array}{c}\text { Dip } \\
(\mathbf{d e g} .)\end{array}$ & $\begin{array}{c}\text { Rake } \\
(\mathbf{d e g} .)\end{array}$ & $\begin{array}{c}\text { Slip } \\
(\mathbf{m})\end{array}$ \\
\hline 59.17 & 144.12 & 1 & 50.1 & 190 & 256 & 12 & 90 & 15 \\
\hline 59.36 & 143.23 & 3 & 51.1 & 141 & 250.4 & 10 & 90 & 15 \\
\hline 59.54 & 142.42 & 5 & 47.8 & 114.8 & 245.8 & 6 & 90 & 15 \\
\hline 59.94 & 141.21 & 5 & 79.7 & 99.6 & 237.8 & 8 & 90 & 15 \\
\hline
\end{tabular}

\section{Scenario 6. Rupture of the Yakutat-Yakataga segment}

The event is a hypothetical earthquake that ruptures only the YY segment, which we parameterize using four sub-faults listed in table 3 . The vertical coseismic deformations for this scenario are shown in figure 10c.

The previous investigations by Nicolsky and others (2011b, 2013) show that a rupture of the Prince William Sound block alone, as well as rupture of the Prince William Sound and Kodiak blocks together, result in nearly identical tsunami inundation zones for communities in Prince William Sound. Thus for the community of Chenega Bay we conclude that the tsunami inundation modeled according to a rupture of the Prince William Sound segment of the 1964 area is well-approximated by scenarios 1-3. Because the Prince William Sound and Kodiak rupture zones have different recurrence intervals, with estimates of the recurrence interval for $M_{S}$ 7.5-8 earthquakes in the KI segment being as low as 60 years (Nishenko, 1991 [as cited in Johnson and others, 1996]), we consider two hypothetical scenarios that model a rupture of the Kodiak asperity of the 1964 zone.

Scenario 7. Modified 1964 event: Kodiak asperity of the JDM This event is a hypothetical earthquake that ruptures eight subfaults in the Kodiak asperity from the deformation model by Johnson and others (1996). Vertical coseismic deformations for this scenario are shown in figure $10 \mathrm{~d}$.

Scenario 8. Modified 1964 event: Kodiak asperity of the SDM This event is a hypothetical earthquake that ruptures the Kodiak asperity from the deformation model by Suito and Freymueller (2009). Vertical coseismic deformations for this scenario are shown in figure $10 \mathrm{e}$.

\section{Model of the Cascadia Subduction Zone Earthquake}

Paleoseismic records reveal that great tsunamigenic earthquakes repeatedly occur in the Cascadia subduction zone with irregular intervals averaging about 500 years (Atwater, 1987), often accompanied by a tsunami. The latest trans-Pacific tsunami generated by an earthquake at Cascadia occurred in January 1700 (Satake and others, 1996; Atwater and others, 2005). Probably because of low population density along the Alaska coast, the impact of this tsunami on local communities was not noticed. Multiple models of the Cascadia zone rupture are suggested by Satake and others (2003) and Priest and others (2009), and in references they cite. These models describe hypothetical coseismic displacement fields of the
Cascadia rupture, with various levels of detail. Because a Cascadia subduction zone earthquake is considered to be a medium-distance tsunami source to the south-central Alaska coast, a relatively simple "worst case, but credible" rupture of the Cascadia subduction zone is used in our modeling.

Scenario 9. Rupture of the Cascadia zone, including portions of the margin along the British Columbia and northern California shores

Tsunami heights in Japanese historical records can constrain the slip distance of the 1700 Cascadia earthquake (Satake and others, 1996), but do not place robust constraints on the downdip limit of the rupture (Wang and others, 2003). A conservative approach for Cascadia is to assume that full coseismic rupture takes place over the entire locked zone and the slip decreases linearly downdip halfway into the present effective transition zone. The most recently updated and probably more reasonable model assumes that the slip distribution in the downdip direction is bell shaped on a plot of slip versus distance from the trench (Geological Survey of Canada, K. Wang, written commun., 2010), which is different from what was used to model the coseismic deformation shown in figure 14 of Wang and others (2003). In this report, the assumed rupture recovers 1,200 years equivalent of plate convergence (Witter and others, 2011), about $36 \mathrm{~m}(120 \mathrm{ft})$ slip, and has a magnitude $\mathrm{M}_{\mathrm{w}} \approx 9$. Vertical coseismic displacements for this scenario are shown in figure $10 \mathrm{f}$.

\section{Other Tectonic Source Models of Hypothetical Tsunamigenic Earthquakes}

In recent studies, Carver and Plafker (2008) and Shennan and others (2009) present evidence of multiple great earthquakes rupturing the Alaska megathrust and significant resultant ground surface displacement along the Gulf of Alaska shoreline. Although estimated values of the ground subsidence and uplift are available only at a limited number of locations (Hamilton and Shennan, 2005; Shennan and others, 2008; Carver and Plafker, 2008, and references they cited), they indicate that tectonic plates could have slipped relative to each other differently during each earthquake. The available ground deformation data are scarce and allow neither constraints on the slip distribution in Prince William Sound nor estimates on the location of the zero isobase between coseismic uplift and subsidence displacements during pre-1964 great megathrust events. Uplift near Evans Island may have been smaller during pre-1964 events. If this is the case, more devastating tectonic tsunamis than occurred in 

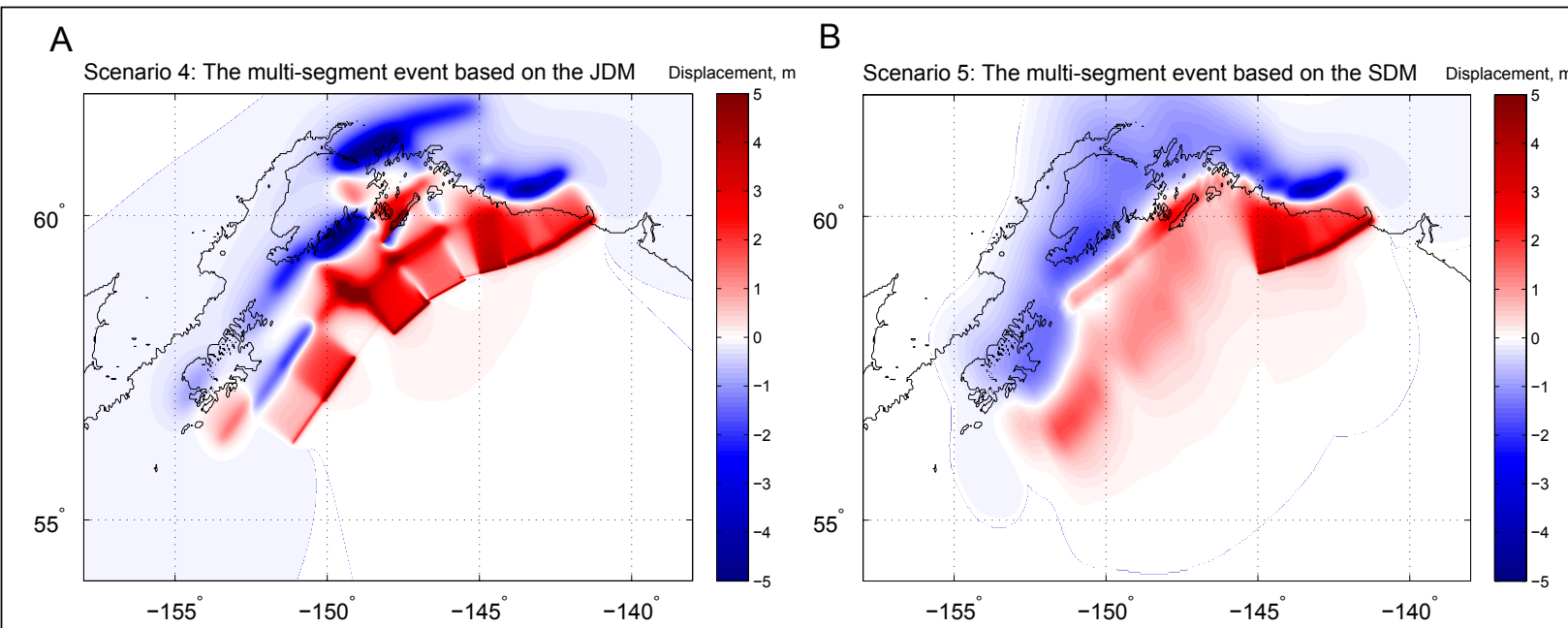

C

D
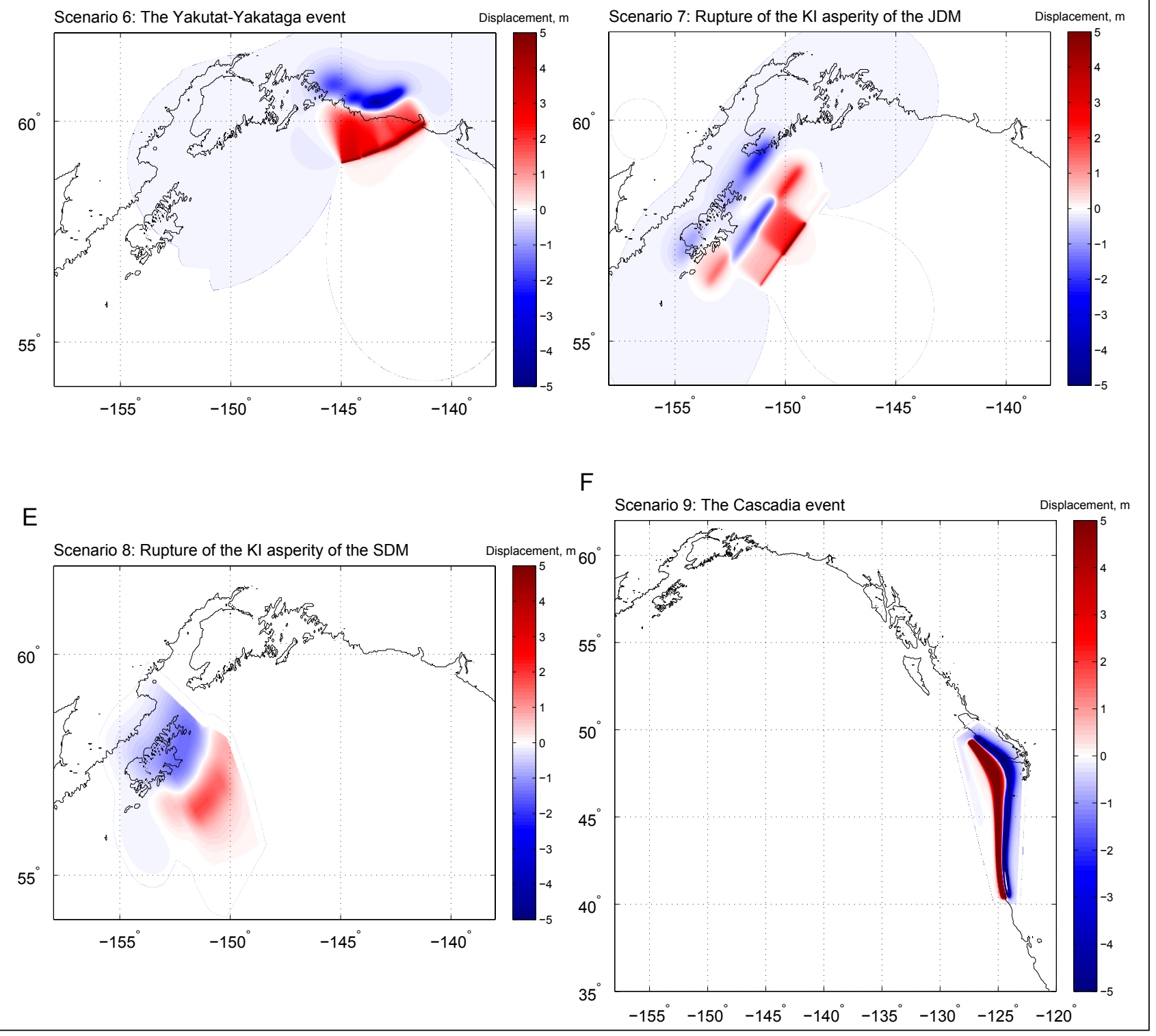

Figure 10. Vertical deformations of the ocean floor corresponding to scenarios 4-9. 
1964 in the Sawmill Bay area are possible. Thus, in addition to assessing the 1964-type events, we considered scenarios of hypothetical earthquakes rupturing the plate interface beneath the Prince William Sound region.

A geodetic study by Zweck and others (2002) in southcentral Alaska revealed the locked regions of the plate interface. Zweck and others (2002) showed that the locked regions are beneath the eastern Kenai Peninsula and western Prince William Sound at depths from 10 to $30 \mathrm{~km}(6.2-18.6$ mi) and correlated this locked zone to the region of high slip during the 1964 earthquake. They concluded that the locked zone is associated with a persistent asperity; however, hypothetical earthquakes might occur in regions even where non-significant locking exists. Suito and Freymueller (2009) estimated the slip deficit accumulating on the locked plate interface and found that most of the slip deficit (such as locking) is found near southeastern Kenai Peninsula, near Bainbridge and Evans islands. The estimated slip deficit model from Suito and Freymueller (2009) is shown in figure 11.
We employed a model of interface between the subducting and overriding Alaska and Aleutian plates. The details of the plate interface reconstruction can be found in Nicolsky and others (2013). The plate interface model was discretized into a number of small rectangles. An upper and lower edge of each rectangle is coincident with a depth contour of the reconstructed plate interface (fig. 12). The rectangles, or socalled sub-faults, are later used to compute coseismic ground deformation using formulas in Okada (1985). Once the model of the plate interface was developed, we modeled hypothetical earthquakes by prescribing a slip distribution along the interface and computed the slip at the center of each subfault. Similar to Geist and Dmowska (1999) and Sobolev and others (2007), we used theoretical slip distribution formulas by Freund and Barnett (1976) to model coseismic vertical deformation. The most important parameters in the Freund and Barnett formulas are the upper and lower boundaries of the hypothetical rupture in the local downdip direction. These boundaries prescribe a range of depths at which the hypothetical earthquake occurs.

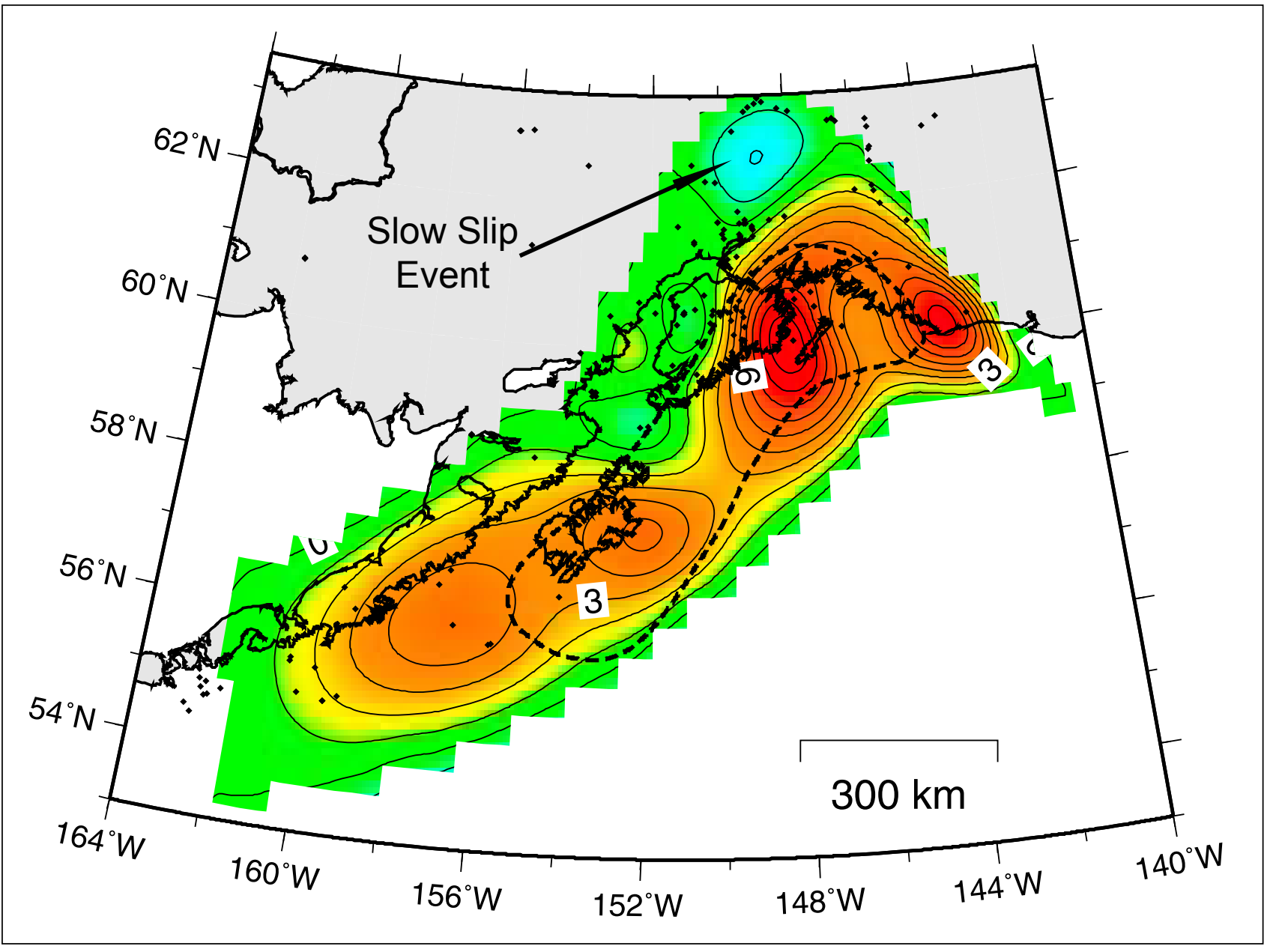

Figure 11. Contour plot (from Suito and Freymueller, 2009) of the reconstructed interseismic slip deficit, an accumulation of the potential displacement on the fault during the earthquake. Black solid lines are related to contours with a $1 \mathrm{~cm} /$ yr (0.39 in/yr) interval. Labels in white rectangles mark $3 \mathrm{~cm} / \mathrm{yr}(1.17 \mathrm{in} / \mathrm{yr})$ and $6 \mathrm{~cm} / \mathrm{yr}(2.34 \mathrm{in} / \mathrm{yr})$ contours. Red marks positive slip deficit regions, where the accumulation stress occurs. Blue represents negative slip deficits potentially related to previous interseismic slip events, such as the 1998-2001 slow-slip event (Ohta and others, 2006). 


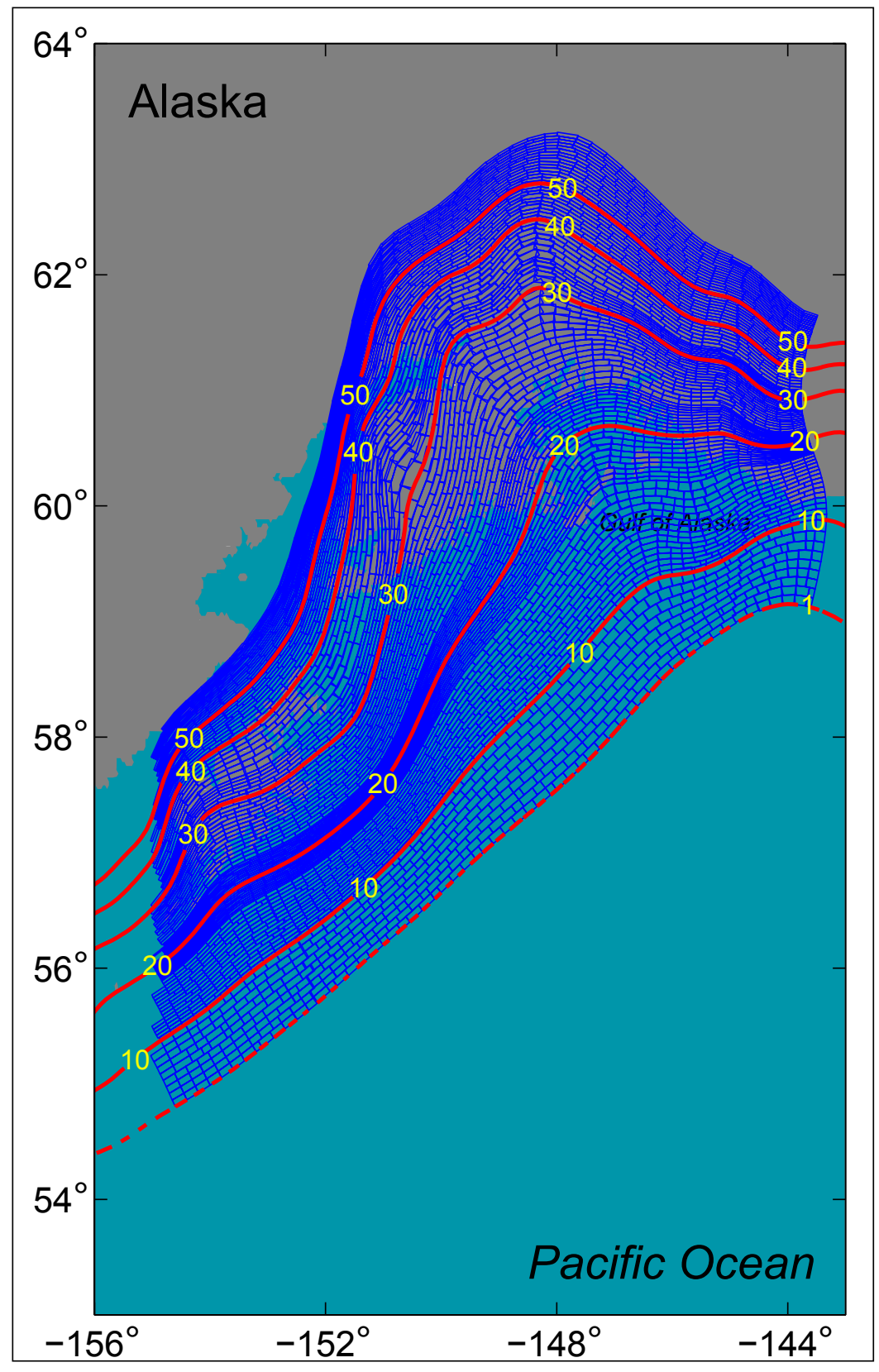

Figure 12. Discretization of the plate interface model into a set of rectangles used to compute the coseismic vertical displacement using formulas from Okada (1985). Red lines and labels mark depth contours (in kilometers below the ground surface) of the reconstructed plate interface.

Based on the information described above, we constructed an additional scenario; specifically, we simulated a hypothetical Tohoku-type event in the Gulf of Alaska region. The assumed moment magnitude for this hypothetical event is 9.0; the proposed slip distribution is shown in figure 13a. Slip at the center of each sub-fault is in meters and is marked by color; depth contours of the plate interface model are in kilometers and are shown by red lines. After reviewing the results of several scenario runs with various slip distributions, we chose the scenario with the maximum slip across from the community of Chenega Bay, which is marked by a yellow circle. The rupture occurs between depths of 4 and $18 \mathrm{~km}(2.5-11.2 \mathrm{mi})$.

\section{Scenario 10. Tohoku-type event}

This hypothetical Tohoku-type event is based on a $M_{w} 9.0$ earthquake in the Gulf of Alaska region. The slip is distributed in the alongstrike direction according to the slip deficit model in Suito and Freymueller (2009) and is localized between 4 and $18 \mathrm{~km}(2.5-11.2$ mi) depth according to the parameterization by Freund and Barnett (1976), with $\mathrm{q}=0.5$. The vertical coseismic deformation for this scenario is shown in figure $13 \mathrm{~b}$.

\section{MODELING RESULTS}

\section{NUMERICAL MODELING OF THE 1964 TSUNAMI IN SAWMILL BAY: MODEL VERIFICATION}

In this section, we compare inundation modeling results of the 1964 tsunami with collected measurements at the present location of the Chenega Bay village on the coast of Sawmill Bay. To model inundation of coastal areas, we use a series of nested grids. Recall that the lowest resolution 2-arc-minute grid spans the Gulf of Alaska, while the highresolution grid covers Sawmill Bay. We note that the high-resolution DEM is not digitally edited to remove post-1964 construction; however, there has been only minor offshore development since the 1964 event.

The developed DEM has the present-day MHHW vertical datum, which was adjusted to model the sea level at the onset of the earthquake. First, we accounted for the uplift of the Sawmill Bay area. Second, we estimated that at the time of the main shock, the water level was $0.3 \mathrm{~m}(1.0 \mathrm{ft})$ above the MLLW as it was in the nearby communities, such as Seward and Whittier (Kachadoorian, 1965; Lemke, 1967). Thus, to reconstruct the pre-1964 DEM with the correct water level, we first subtracted the vertical coseismic displacement (its value depends on the considered scenario), and then set the sea level equal to $0.3 \mathrm{~m}(1 \mathrm{ft})$ above the MLLW level ${ }^{5}$.

According to scenarios 1-3, the Sawmill Bay area is displaced in the south-southeast direction by $18.5 \mathrm{~m}(60.7 \mathrm{ft})$,

${ }^{5}$ The tidal range on the neighboring Latouche Island is $3.55 \mathrm{~m}$ (11.6 ft) from MHHW to MLLW. We note that currently MLLW is $1.88 \mathrm{~m}(6.17 \mathrm{ft})$ below MSL as opposed to $3.49 \mathrm{~m}$ (11.4 ft) in 1964. In this work the change in the MLLW datum as well as the post-seismic rebound in Sawmill Bay were assumed to be negligibly small. 


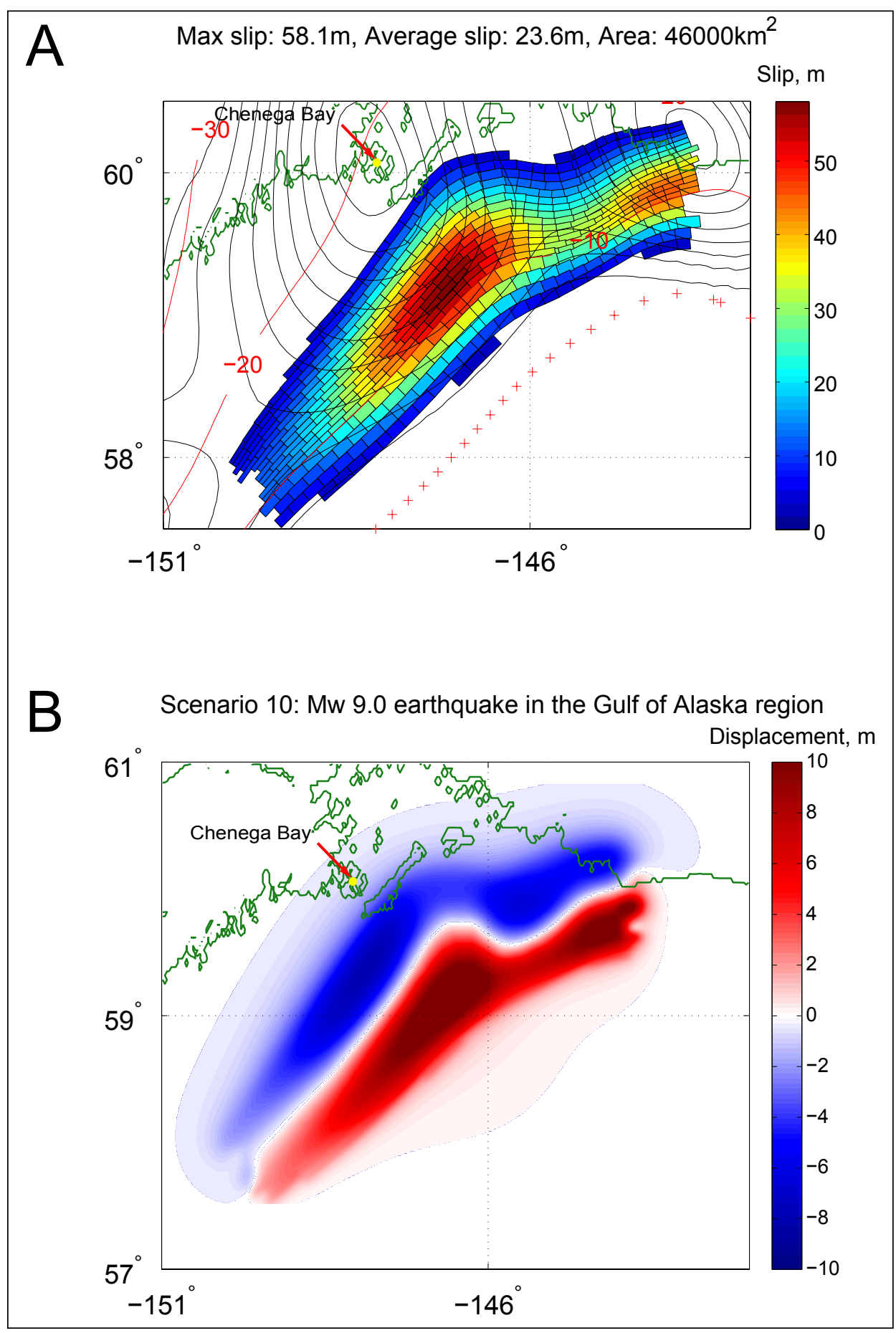

Figure 13. A. Proposed slip distribution along the plate interface for hypothetical Tohokutype $M_{w} 9.0$ events in the Gulf of Alaska region. Slip-deficit contours are shown by black lines. Red lines are associated with depth contours in kilometers. The Alaska-Aleutian trench is marked by red crosses. The community of Chenega Bay is shown by a yellow circle marked with a red arrow. B. Computed vertical ground surface deformation related to the proposed slip distributions in scenario 10 . Blue areas are associated with coseismic ground subsidence, while areas of uplift are shown in red. 
$16.7 \mathrm{~m}(54.8 \mathrm{ft})$, and $14.5 \mathrm{~m}(47.5 \mathrm{ft})$ and uplifted by $2.5 \mathrm{~m}$ $(8 \mathrm{ft}), 2.4 \mathrm{~m}(8 \mathrm{ft})$, and $2.1 \mathrm{~m}(7 \mathrm{ft})$, respectively. It is estimated that the land displacement ${ }^{6}$ in the PWS region occurred within the tsunami rise time $\boldsymbol{t}_{\mathrm{r}}=60$ seconds (Nicolsky and others, 2012). This rise time is not sufficient for the initial water disturbance (caused by a quick push of land against water) to propagate far from the shore under the force of gravity. Thus, immediately after the onset of the land displacement process, the water level rises along the northern shore of Sawmill Bay. Figure 14 shows the computed water level in Sawmill Bay, just offshore of Chenega, at point 18 shown in the first plot in figure A-1 (appendix A). The vertical dashed line marks the beginning of the rise time interval, and the dashed-dotted line corresponds to its end, that is, the moment when the ground displacement ends. According to the computer experiment, an initial wave forms during the rise time, but it recedes and some drawdown occurs. According to scenarios 1-3, the water level lowers by approximately $5 \mathrm{~m}(16 \mathrm{ft})$ as shown in figure 14. The modeled sequence of events and magnitude of the computed drawdown quantitatively agrees with the 1964 eyewitness observations. However, an observed full drainage of Crab Bay does not occur in the computer experiment immediately after the earthquake, as eyewitness reports claim (Plafker and others, 1969).

The eyewitnesses reported that a few moments after the drawdown, water violently rushed back up to the elevation of $3 \mathrm{~m} \mathrm{(10} \mathrm{ft)} \mathrm{"above} \mathrm{the} \mathrm{extreme} \mathrm{high-tide} \mathrm{level} \mathrm{along} \mathrm{seg-}$ ments of the uplifted shore" in the vicinity of Sawmill Bay (Plafker and others, 1969). We note that the altitude of this level on the present-day high-resolution DEM is equal to the magnitude of the tectonic uplift. Assuming that immediately before the earthquake, the sea level was about $3.4 \mathrm{~m}(11.2 \mathrm{ft})$ below the MHHW level, we find that the 1964 tsunami surged up to $3.4+3.0=6.4 \mathrm{~m}(21 \mathrm{ft})$ above the sea level at the onset of the earthquake.

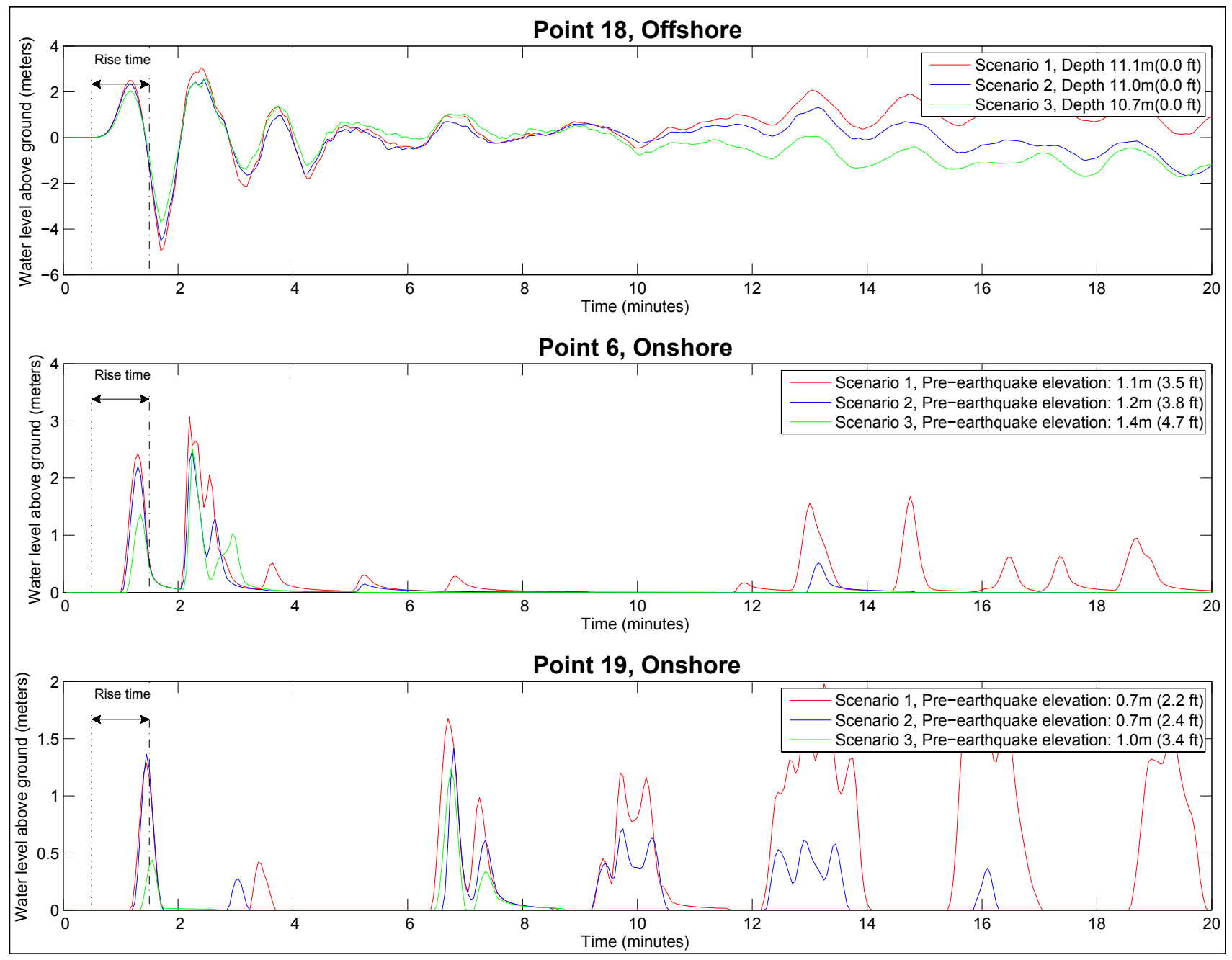

Figure 14. Computed water level at points 18, 6, and 19 for the cases of PDM, JDM, and SDM are displayed by red, blue, and green lines, respectively. Water level is shown from a point of view of an onshore observer after being uplifted during the earthquake. Point locations are displayed in appendix A1. The interval during which land displacement occurred (rise time) is marked by vertical dotted and dash-dotted lines.

${ }^{6}$ The rate of displacements is parameterized by a bell-shaped function, i.e. $\approx \exp \left(-\alpha\left(\mathrm{t}-\mathrm{t}_{0}\right)^{2}\right)$, where $\alpha$ is selected such that the most of deformation occurs within the time interval $\left[\mathrm{t}_{0}-\mathrm{t}_{\mathrm{r}} / 2, \mathrm{t}_{0}+\mathrm{t}_{\mathrm{r}} / 2\right]$. 
Our computer experiments show development of a secondary wave after the drawdown. For example, at point 18 , the height of the second wave is almost equal to that of the first wave. At point 6 , this secondary wave reaches $3 \mathrm{~m}$ $(10 \mathrm{ft})$ above the ground. Noting that point 6 is $1.2 \mathrm{~m}(4 \mathrm{ft})$ above the sea level prior to the event, we find that the modeled tsunami surges to $3.0+1.2=4.2 \mathrm{~m}(13.8 \mathrm{ft})$ above the pre-earthquake sea level, or $4.2-3.4=0.8 \mathrm{~m}(2.6 \mathrm{ft})$ above the uplifted MHHW level, while near point 6 , the computer experiment tsunami surges a little higher. The computed wave heights are smaller than the observed wave heights, but the timing of the modeled events is in good agreement with observations, that is, the first and second waves occurred within 4-5 minutes after the earthquake's onset.

Distributions of the runup computed according to scenarios 1-3 are shown in figure 15 . On the left column, we display the runup in Sawmill Bay and parts of Latouche and Elrington passages. The black arrows mark locations where observations were made shortly after the 1964 tsunami; see figure 2. Panels in the right column show an enlarged copy of the same runup distribution, but now at the location of the present-day village, that is, between Crab and Sawmill bays.

We emphasize that the runup computed according to scenarios 2 and 3 is less than the runup according to scenario 1. An explanation is that the JDM (scenario 2) and SDM (scenario 3) seem to underpredict the observed lateral displacement (PDM, or scenario 1), and thus the numerical experiments based on scenarios 2 and 3 result in smaller wave heights than those that use scenario 1 . The runup modeled according to scenario 1-if compared to the 1964 observations - is slightly underpredicted due to either the uncertainties in the tsunami generation mechanism or the exploited shallow-water equations. Finally, we note that, notwithstanding differences in the computed runup values, patterns of the computed and observed runup (fig. 2) qualitatively agree with each other and can be used to evaluate tsunami hazards in Sawmill Bay.

The arrival of a tsunami from the Gulf of Alaska is illustrated in figure 16, in which simulated water levels at points 17 and 18 are shown for scenarios $1-3$. Limitations of the PDM restrict modeling of the water dynamics in Sawmill Bay to only the first 20 minutes after the initial land displacement. Therefore, the time series (red line) for scenario 1 is much shorter than the time series (blue and green lines) for scenarios 2 and 3. For each location, we display two plots of the water level described below.

The upper plot shows the simulated tsunami dynamics from the point view of an observer standing on the coast of Sawmill Bay. While simulating a tsunami, we do not take into account interactions between the tsunami and tides, and consequently the computed water level does not show a tide signal. We indicate that the simulated water level after 9-10 hours stays close to an elevation of $2.5 \mathrm{~m}(8.2 \mathrm{ft})$ below zero. This phenomenon is explained by the fact that Evans Island, as well as the observer standing on its shore, became elevated by about $2.5 \mathrm{~m}(8.2 \mathrm{ft})$, and hence the water level (after the tsunami waves have disappeared) appears to be a lower level from the point of view of the observer.
Sea level change from astronomic tides is a relatively slow process - if compared to the rapid sea level variations due to the tsunami - and it is possible to decouple these two processes. As Sawmill Bay is connected to the Gulf of Alaska by deep passages, the nonlinear interaction of the tsunami and tides could be assumed to be small in Sawmill Bay. Refer to Kowalik and others (2006) and Kowalik and Proshutinsky (2010) for a robust discussion of tsunami-tide interaction. We simulate the 1964 tsunami without tidal forcing, and then superimpose the computed tsunami with the tide in Sawmill Bay as follows. We corrected the simulated water depth by adding the predicted tidal dynamics of the evening on March 27, 1964. Thus, the corrected water level dynamics are shown in figure 16 as the lower plots for each point; the vertical datum corresponds to the pre-earthquake MHHW level. The tide signal is displayed by a magenta line. The elevation of the MHHW level of the uplifted shore is marked by the dashed black line. The vertical double-headed arrows at the beginning of the series show an approximate value of the tectonic uplift. Because the vertical datum corresponds to the pre-earthquake MHHW level, and because the horizontal dashed line marks the MHHW level of the uplifted coast, the elevation of this line is also equal to the tectonic uplift.

Note that 9-10 hours after the earthquake, the simulated waves are much smaller than at the beginning of the computed experiment, and the computed water level is close to the assumed tide signal. However, 6-7 hours after the earthquake the simulated water level approaches the high-tide level of the uplifted shore. This phenomenon might explain an observed wave during a rising tide at 1:00 am on March 28, 1964, about 7.5 hours after the earthquake. According to Plafker and others (1969), the observed 1:00 am wave reached close to the tectonically elevated extreme high-tide level, but caused no damage.

We conclude that we obtain a good comparison between the modeled and observed tsunami dynamics in Sawmill Bay and its vicinity by improving the tsunami generation mechanism as described in Nicolsky and others (2012). The best comparison is obtained in the case of scenario 1 , but the modeled time is restricted to the first 20 minutes of the tsunami dynamics, when most of the damage occurs. The second best comparison is obtained in the case of scenario 2 .

\section{RESULTS OF HYPOTHETICAL TSUNAMI SCENARIOS}

We performed numerical calculations for all the abovementioned scenarios. For each considered scenario, we modeled the water dynamics, and then computed the extent of the tsunami inundation. The considered tsunami scenarios can be divided into three distinct groups. The first group consists of scenarios in which the hypothetical rupture is based on the various models of the 1964 rupture, namely scenarios $1-5$. The second group is composed of scenarios 6-9, where an earthquake source is distant from Sawmill Bay. Finally, the third group consists of scenario 10, which simulates a Tohoku-type rupture in the Gulf of Alaska. 


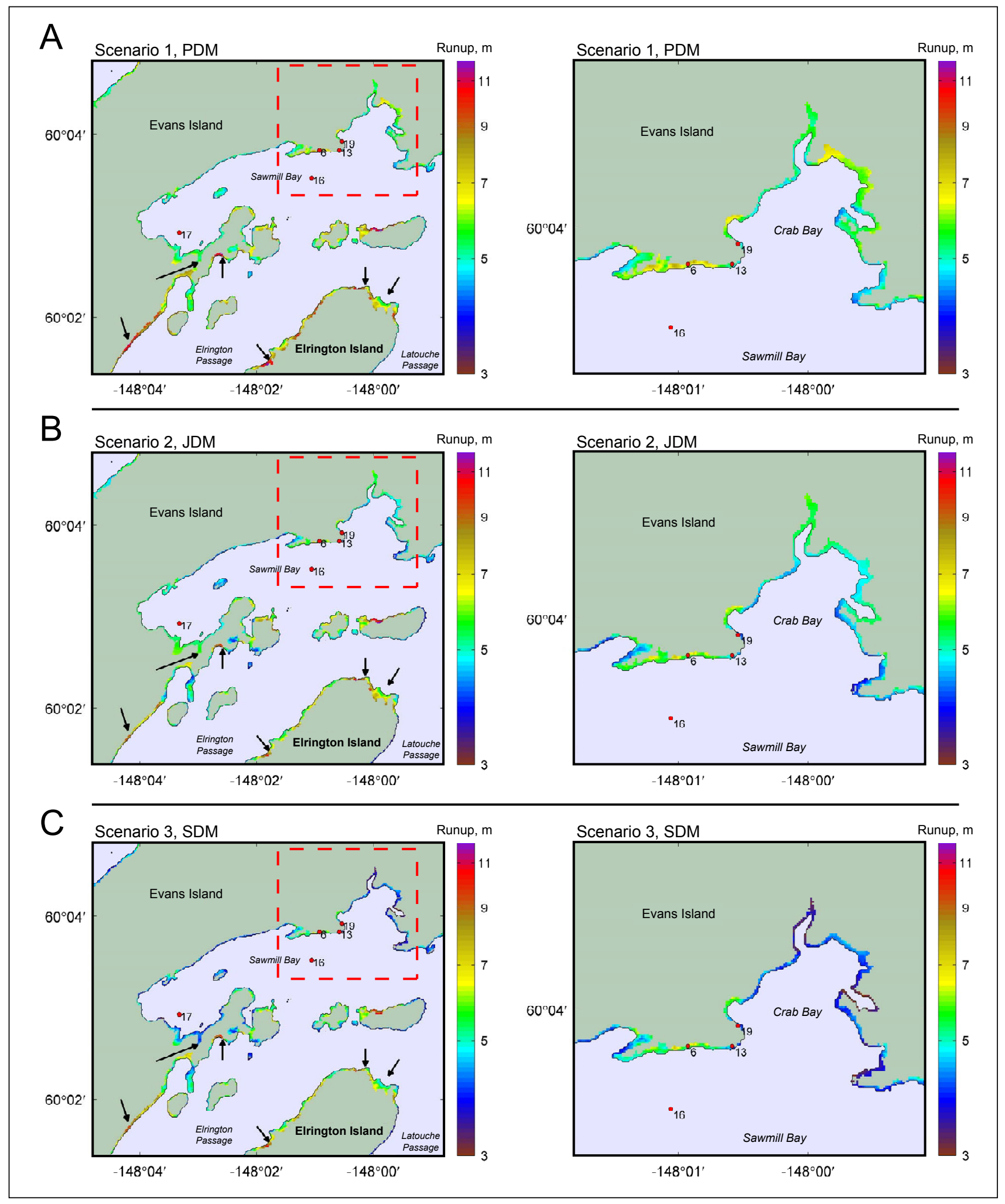

Figure 15. Modeled runup heights in Sawmill Bay and vicinity (left column) and Crab Bay (right column) during the 1964type events. (A) Scenario 1, PDM; (B) Scenario 2, JDM; and (C) Scenario 3, SDM. The location of Crab Bay is shown by a dashed red square on plots in the left column. Black arrows point to locations where observations of the tsunami runup during the 1964 event are available. The largest horizontal displacement is associated with scenario 1, which also shows the largest values of the simulated runup. 


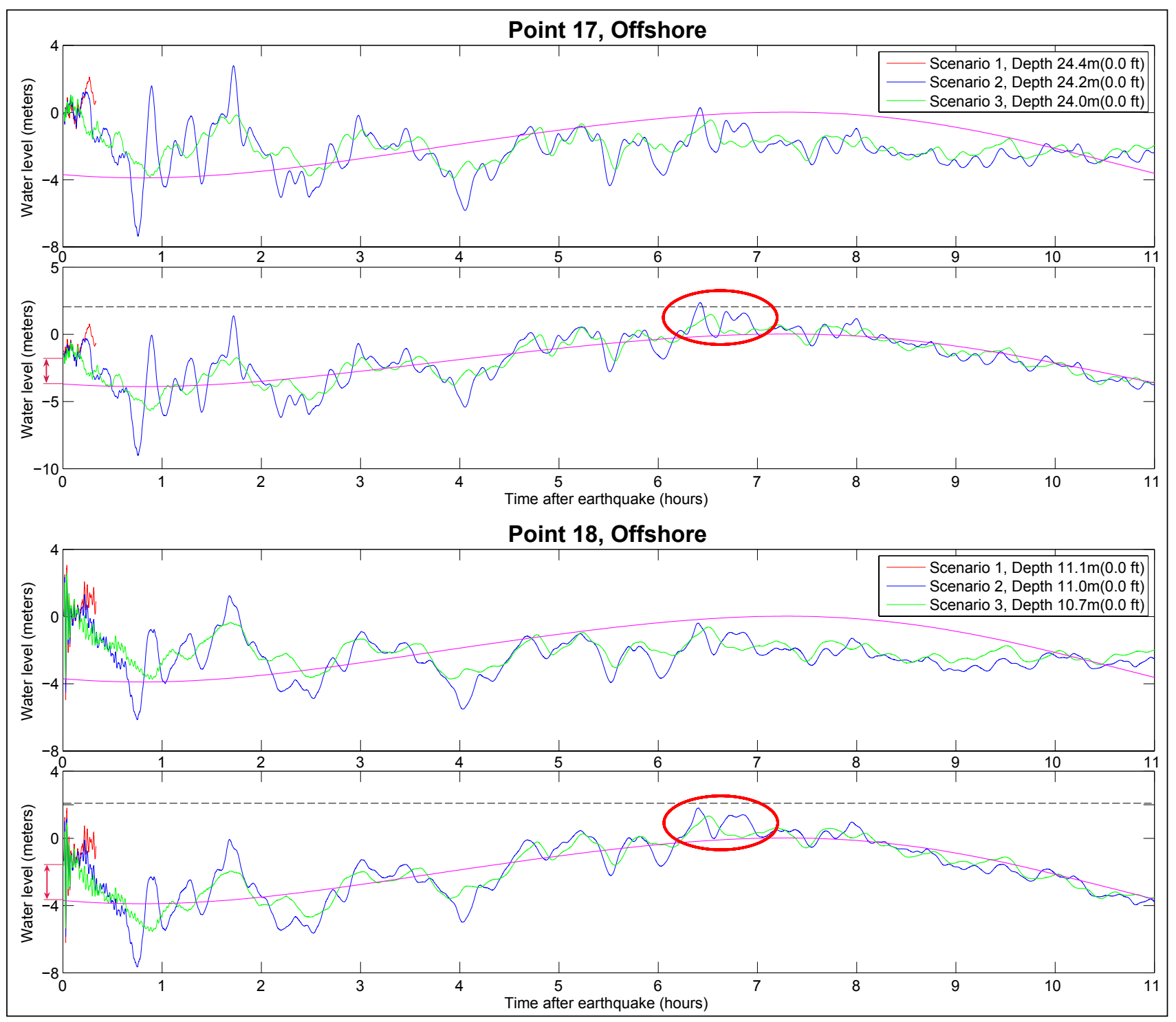

Figure 16. Reconstructed tide level and modeled offshore water level in Sawmill Bay at points 17 and 18 (see appendix A-1 for locations) after the 1964 earthquake. For each point, the top plot shows the modeled water level dynamics, based on the PDM, JDM, and SDM, from a point of view of an observer standing at the pre-earthquake shoreline. Predicted tide dynamics in Sawmill Bay are shown by the magenta line, with the pre-earthquake MHHW vertical datum. The bottom plot for each point illustrates the tide-corrected simulated water level. On both panels, the water level is in meters with respect to the pre-earthquake MHHW level. Vertical double-headed arrows at the beginning of the series indicate a value of the tectonic uplift; the dashed black line marks the MHHW level of the elevated coast; red circles indicate a time interval during which the flooding on low-lying, tectonically elevated areas is thought to occur at the high tide after the earthquake.

We begin discussion of the modeling results by noting that the scenarios in the first group simulate vertical and horizontal displacement of the Sawmill Bay region. The large horizontal land displacements during the hypothetical events, together with abrupt changes in the bathymetry near the community of Chenega Bay, result in an immediate wave during the land displacement process. Some highly localized waves lead to substantial runup along the shoreline of Sawmill Bay as well as in Elrington and Latouche passages, and in the computer experiment large tsunami inundation extents are evident in these areas.
The local land displacements in the vicinity of Sawmill Bay are the primary cause of the water runup, so the computed runup distributions associated with the 1964-type and the extended 1964 rupture zones are almost identical near Sawmill Bay. The largest variability in the runup is related to the assumed earthquake source, defined by scenario 1, 2, or 3. Since the horizontal displacements in scenario 1 are the largest among the scenarios in the first group, the computed runup in this case is the greatest. Values of the runup for other scenarios are a little smaller, but they qualitatively agree with one another and show spatial variability similar to that observed during the 1964 event. 
In contrast, scenarios in the second group correspond to negligibly small displacements in the Sawmill Bay area, and consequently the tsunami arrives into Sawmill Bay only after a certain period of time. For example, tsunamis triggered by rupturing of the Kodiak Island (KI) asperity of the 1964 event (scenario 8 or 9) can arrive in Sawmill Bay 1 hour after the earthquake. The wave heights do not exceed 0.9 $\mathrm{m}(3 \mathrm{ft})$ and the modeled tsunami produces only a moderate inundation of low-lying areas. The tsunami generated by a hypothetical rupture of the Cascadia zone (scenario 9) can arrive at Sawmill Bay within 4 hours after the event, and the wave height is about $1.5 \mathrm{~m}(5 \mathrm{ft})$.

Finally, scenario 10 reveals a devastating tsunami, which could occur in Sawmill Bay if a Tohoku-type rupture occurs in the Gulf of Alaska. The potential wave can arrive within about 1 hour after the earthquake and its height in Crab Bay may reach $10 \mathrm{~m}(33 \mathrm{ft})$. The rapid rise of water may coincide with the formation of bore-like waves and the actual height of the tsunami could be higher.

In figure 17, we show the maximum modeled composite inundation extent for each scenario group. The reader is referred to figure 2 to compare the observed inundation in 1964 to the extents based on the hypothetical repeat of the 1964 rupture. We note that along some segments of the shoreline, the modeled tsunami inundation extent (for example, for scenarios 6-9) coincides with the shoreline because of steep topography near the shoreline. At some of these locations, we conservatively extended the tsunami inundation zone by one grid cell inland in order to make the tsunami inundation zone reflect the hazard of the wave breaking at cliffs.

Scenario 10 predicts the largest and most devastating inundation among all considered scenarios. The hypothetical wave might travel farther inland and inundate locations that were not inundated during the 1964 tsunami. Thus, scenario 10 represents the worst-case scenario for the community of Chenega Bay. We note that although the occurrence of a Tohoku-type event is possible, the available geologic evidence suggests that repeated 1964-type events may be a more realistic estimate of future earthquake displacements. Thus, the maximum inundation line from scenarios 1-5 may provide a more plausible estimate of future tsunami inundation.

Tsunami flow depth is an important indicator of potential damage, and must be differentiated from runup height (Synolakis and Bernard, 2006). Thus, in addition to the computed tsunami inundation extents, in figure 18 we show the maximum composite flow depth from all scenarios. We stress that the tsunami generated according to the worst case Tohoku-type scenario 10 is much more devastating, when compared to tsunamis simulated by other scenarios, and hence the composite inundation from all scenarios is essentially equal to the inundation due to scenario 10 . Similarly, figures 19 and 20 show the maximum composite flow depth from all scenarios around the Armin F. Koernig hatchery-Port Ashton area and the Iktua Bay area. For ease of interpretation, $0.5 \mathrm{~m}(1.6 \mathrm{ft})$ approximately corresponds to knee height and $2 \mathrm{~m}(6.6 \mathrm{ft})$ is just above average body height.

Finally figures 21-23 show the maximum composite flow depth for the above areas based on the more conservative maximum inundation from scenarios $1-5$. We emphasize that due to large uncertainties in the topography, the tsunami inundation extent around the Armin F. Koernig hatchery-Port Ashton area and the Iktua Bay area may contain some errors. Nevertheless, the numerical calculations of the flow depth can provide some guidelines for evacuation planning.

\section{TIME SERIES AND OTHER NUMERICAL RESULTS}

To provide emergency managers the tools they need to assess the tsunami hazard in Chenega Bay, we supplement the inundation maps with the time series of the modeled water level and velocity dynamics at certain locations around Sawmill Bay, and Latouche, Elrington, and Prince of Wales passages. The locations were chosen in cooperation with the city manager of Chenega Bay. For each location shown by a number in appendices A-1a and A-1b, we plot the sea level and water velocity in appendices A-2 and A-3, respectively. The zero time corresponds to the epicenter origin time. Elevations of onshore locations and values of the ocean depth at the offshore locations are given with respect to the preearthquake MHHW datum. Since the velocity magnitude is calculated as water flux divided by water depth, the velocity value can have large uncertainties when the water depth is small. In the plots provided, the velocity is computed only where the water depth is greater than $0.3 \mathrm{~m}(1 \mathrm{ft})$. Further, to facilitate interpretation of the numerical results, we plot the computed water level from the point of view of an observer standing at each location. Note that during the earthquake, the land and ocean are uplifted together, and the final sea level becomes lower than the initial one by the value of the tectonic uplift.

In appendix A-2 we illustrate water level dynamics, computed for some scenarios in the first group during the first two hours after the earthquake. Tsunami dynamics according to scenarios 4 and 5 are rather similar; for clarity we plotted only the results related to scenario 4 . The maximum water level and velocity for the considered scenarios are listed in table 4. We emphasize that because of some limitations in reconstruction of the horizontal and vertical land displacements for scenario 1, the water dynamics in Sawmill Bay for this scenario can be computed for only the first 20 minutes following the onset of the earthquake. Analyses of the displayed time series plots reveal that the tsunami can reach onshore locations within minutes of the earthquake. The water flow depth at some locations exceeds $3 \mathrm{~m}(10 \mathrm{ft})$, with the flow velocity up to $3-4 \mathrm{~m} / \mathrm{s}(10-13 \mathrm{ft} / \mathrm{s})$. Moreover, the computed water level at point 3 shows that the water level can recede by $6 \mathrm{~m}(20 \mathrm{ft})$ to expose a significant part of Crab Bay, as observed by eyewitnesses during the 1964 tsunami.

We note that the water level dynamics computed using the 1964-type rupture zone (scenario 2) and the extended 1964 rupture zone (scenario 4) in the first hour are almost identical. The wave caused by rupture of the YY segment arrives at Sawmill Bay approximately 1.5 hours after the earthquake, but does not significantly contribute to the overall tsunami inundation pattern. 


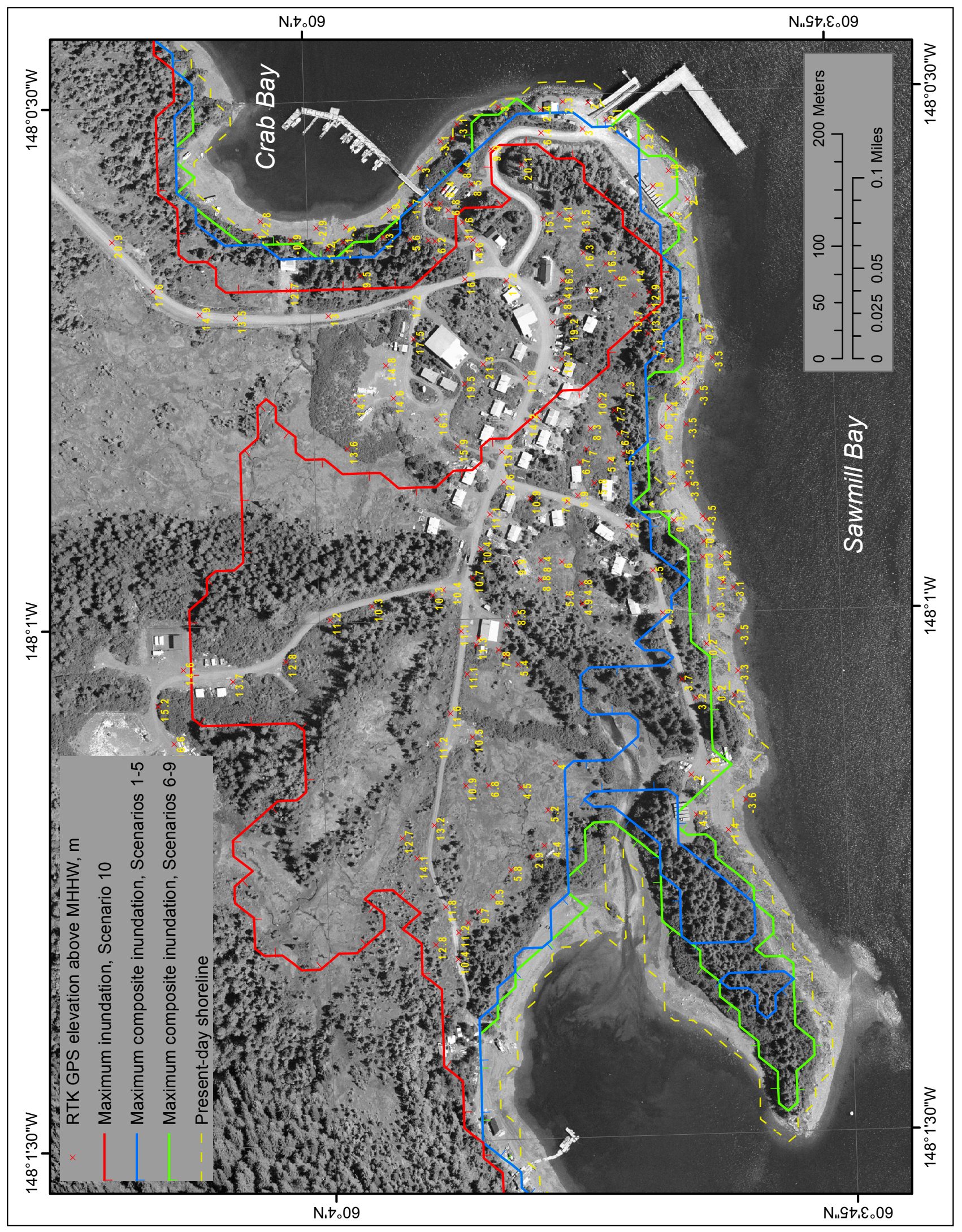

t艹

ว

过

$\sim \cdot \frac{1}{n}$

离 空

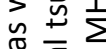

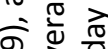

10 它

$\tilde{\circ}$ 守

究的高主

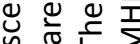

등

证

능 응

ก.

흔

웡응

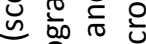

은 응 월

융

ఖ્ّญ

प 0 व

등

궁웡

कू 0 है

ㅁำ बิ

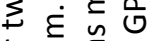

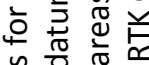

ه

学要

.농

ธ。

प्र

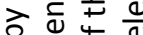

ᄃ बैं 잉

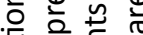

त ब

다 $x$

今웡 응

능

특 등응 궁

ह 유응

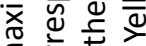

ह 형

त 0 的

致嵌了

웡 중 응

을

항ㅎㅇ 웅

웡 욷ㄷㄴ

을 은 응 잉

\.

궝워

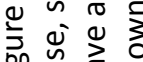

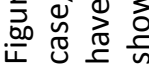




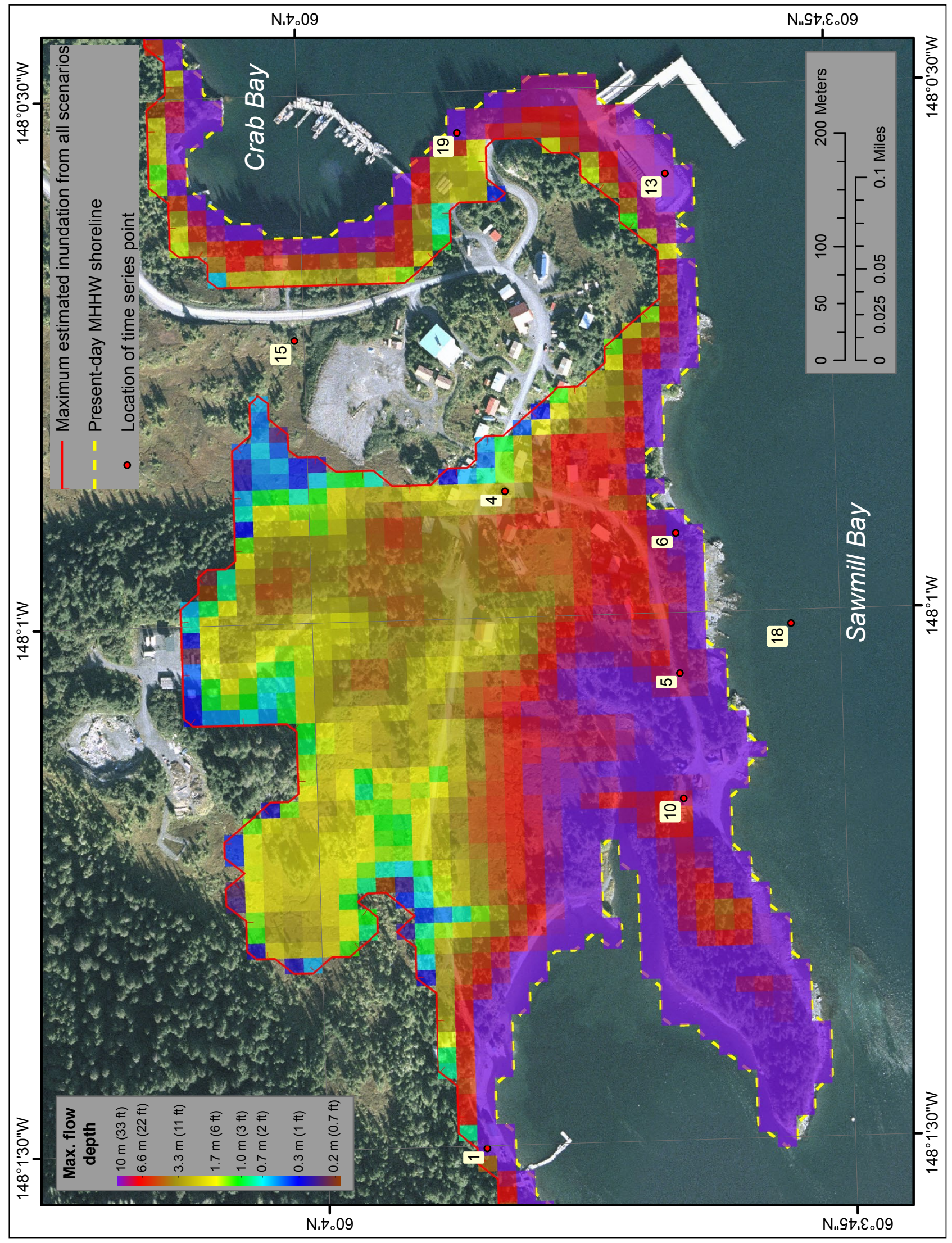

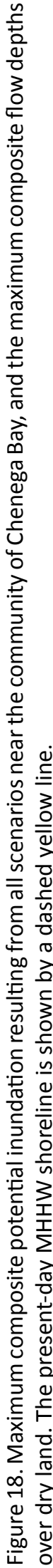




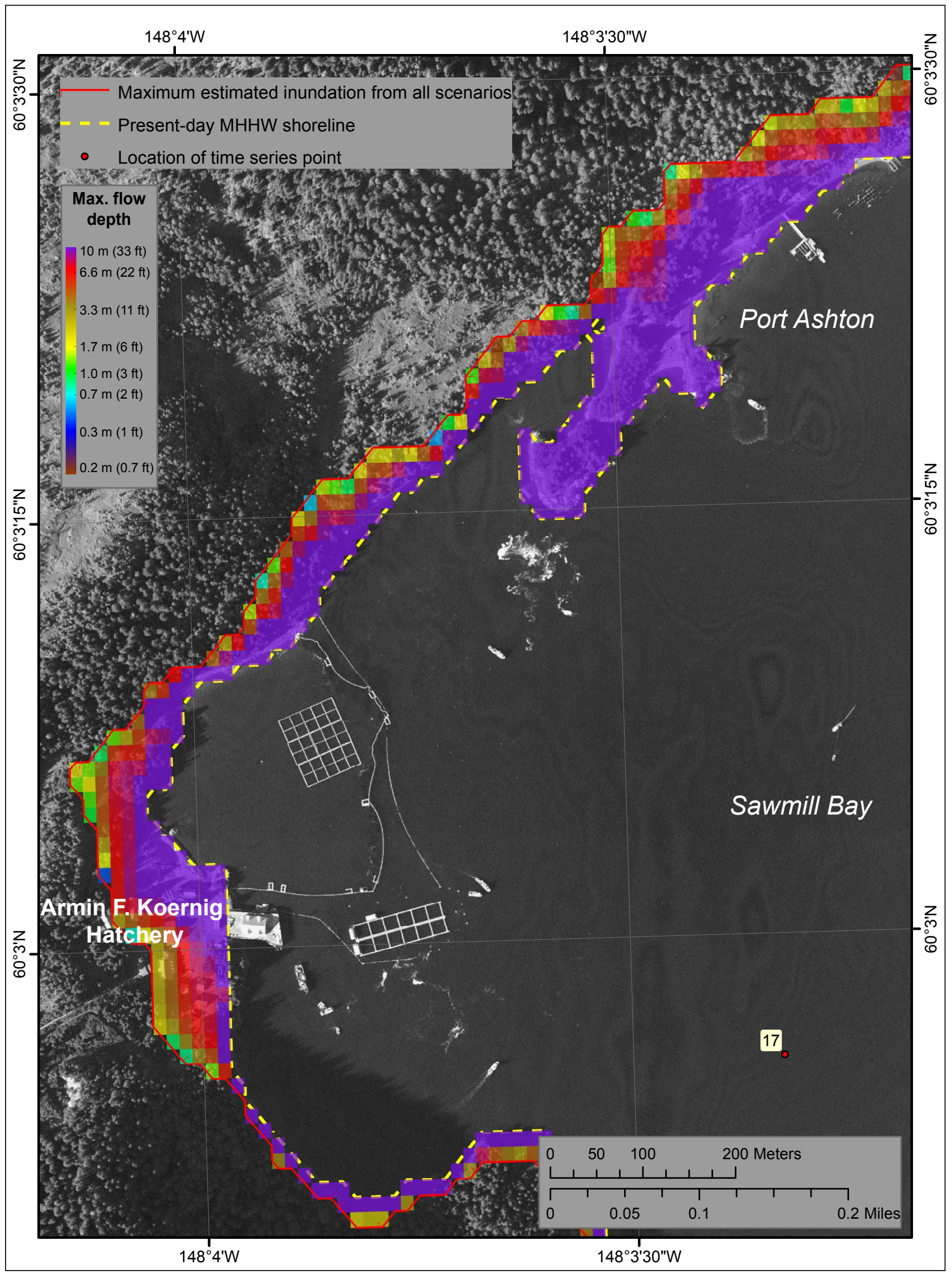

Figure 19. Maximum composite potential inundation for all scenarios in the western part of Sawmill Bay near the Armin F. Koernig hatchery, and the maximum composite flow depths over dry land. Large uncertainties in the DEM in Iktua Bay could severely degrade the accuracy of numerical results. The present-day MHHW shoreline is shown by a dashed yellow line. 


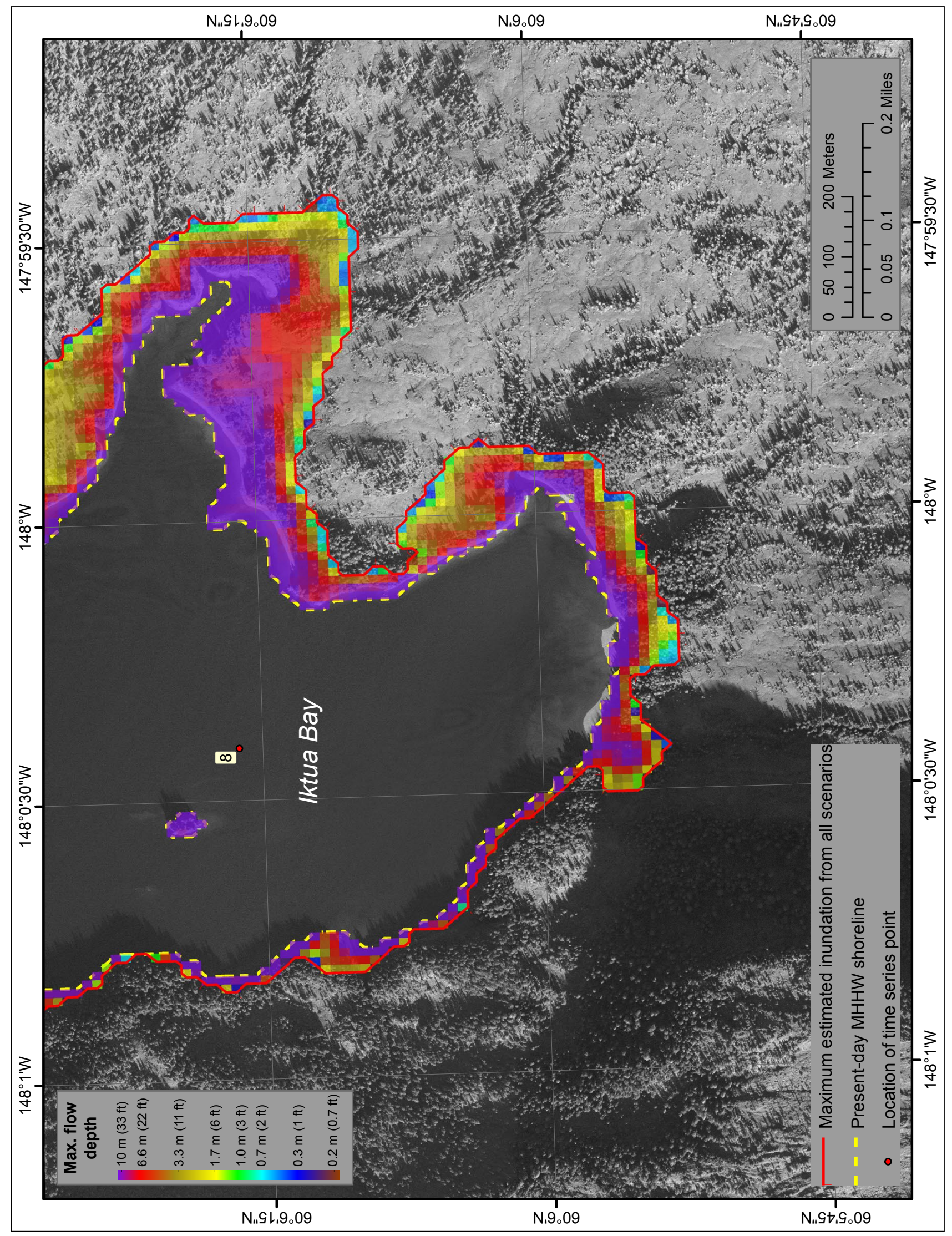

돌

$\frac{0}{0} \frac{1}{n}$

$3 . \frac{n}{9}$

은 $\stackrel{0}{=}$

$\stackrel{0}{ \pm}$

जั 음

है

언

ह $\sum_{\Sigma}$

हे

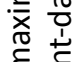

(ิ)

든

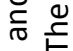

㐫

芩 ญ

$\stackrel{ \pm}{\underline{\underline{ \pm}}} \frac{ \pm}{\mathrm{C}}$

능 은

능

륻

든

岳 就

ㅇํำ

๑ ర్ర

$\subseteq \stackrel{\square}{\check{1}}$

은 웜

즌

वे क्ष

出

ते

ह ำ

은 힌

이듬

픅

ญ ते

들 울

을

言

믐

동

㐫吉

으므

$\stackrel{4}{ \pm}$

ज.

을

ह 넌

엉 巳

$\xi \approx$

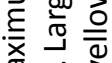

希

$\sum$ 을

유 은

근

인

包 


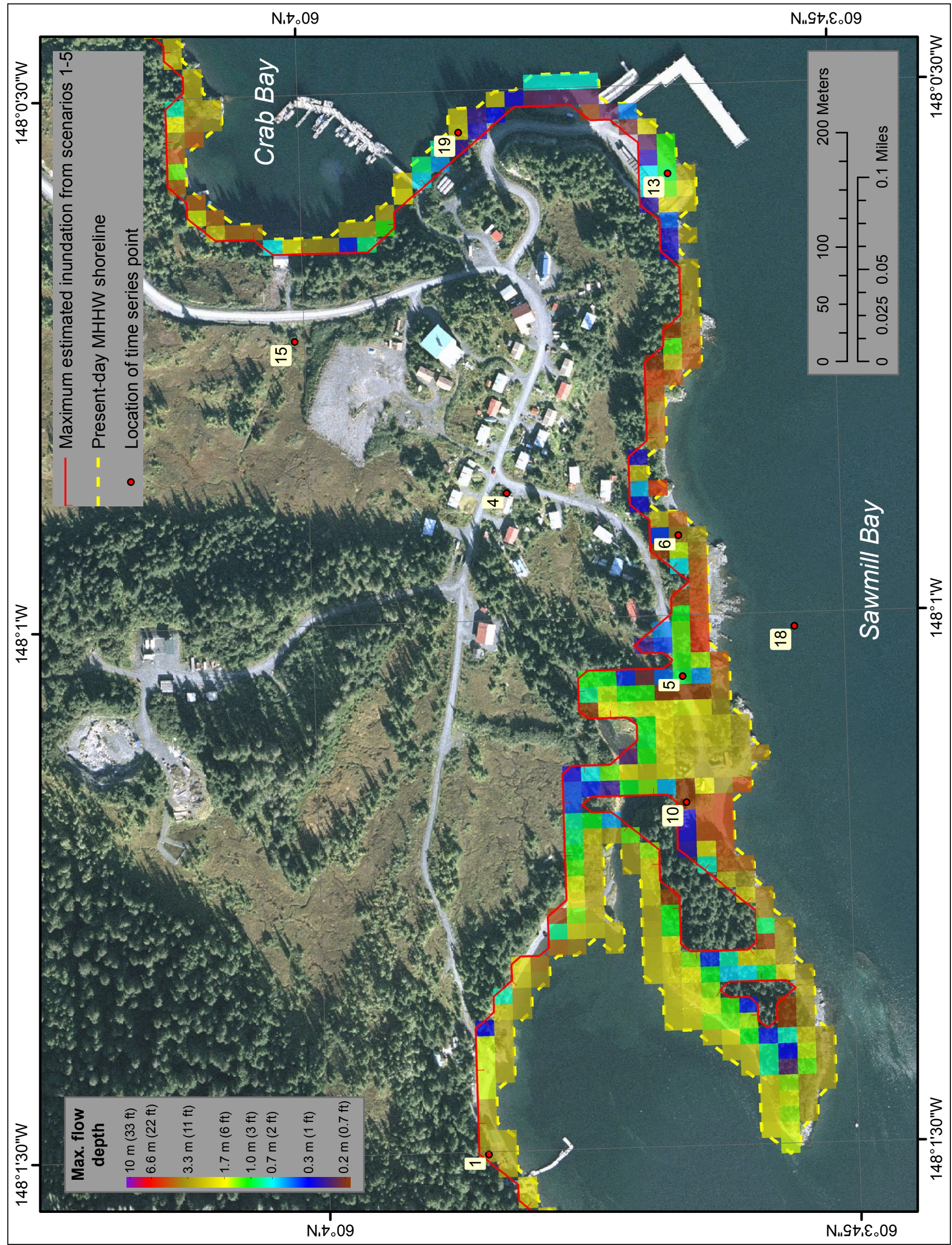

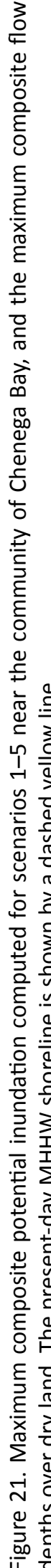




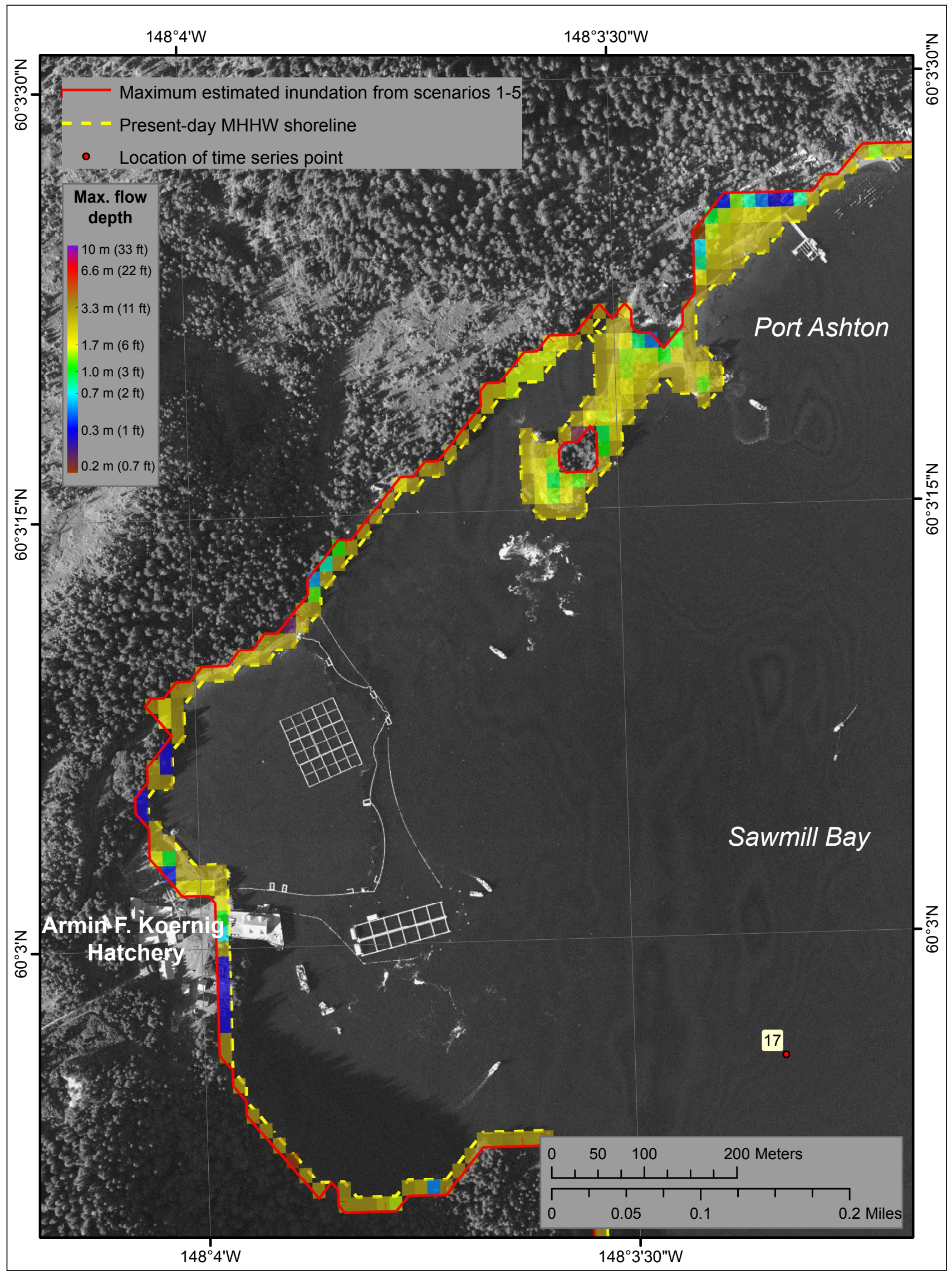

Figure 22. Maximum composite potential inundation for scenarios 1-5 in the western part of Sawmill Bay near the Armin F. Koernig hatchery, and the maximum composite flow depths over dry land. Large uncertainties in the DEM in Iktua Bay could severely degrade the accuracy of numerical results. The present-day MHHW shoreline is shown by a dashed yellow line. 


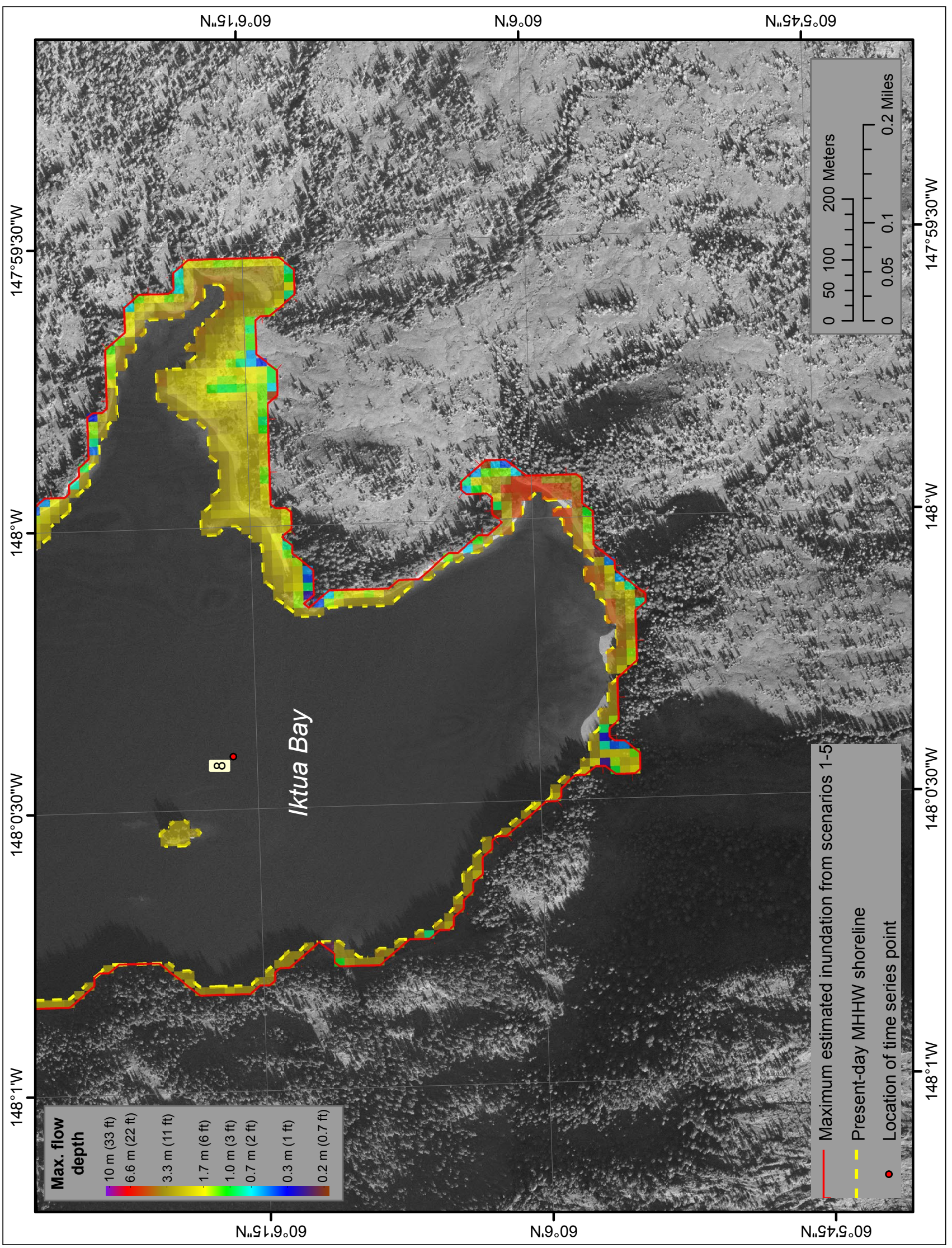

点

$3 . \frac{n}{4}$

年

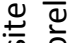

ํํㅇ 음

है

E

弯

질

$\varepsilon$

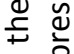

훙

它

齐

西

㞔

능

蒙

을

눙

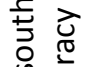

\&

开

$\leq \stackrel{\square}{5}$

뇽

กิ

늠

항

प्र

홍

홍 응

声

है

○

ᄃ응

空

동

宝

.

辛

$\pm$

幽

幽

\%

ह

宅 㚅

है

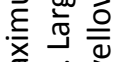

중

당

$\stackrel{\sim}{2} \frac{\mathrm{s}}{\mathrm{s}}$

응

品㐫艺

ํㅜㄴ 
Table 4. The longitude and latitude locations of the time series points. The maximum water level above ground is provided for on-shore locations, whereas the maximum water level above the pre-earthquake MHHW is provided for offshore locations. The onshore $(\mathrm{S})$ and offshore $(\mathrm{O})$ locations are specified in the second column.

\begin{tabular}{|c|c|c|c|c|c|c|c|c|c|c|c|c|c|c|c|c|c|c|c|}
\hline \multirow{3}{*}{ \# } & \multirow{3}{*}{$\mathbf{S} / \mathbf{O}$} & \multirow{3}{*}{$\begin{array}{l}\text { Longitude } \\
\text { (deg. W) }\end{array}$} & \multirow{3}{*}{$\begin{array}{l}\text { Latitude } \\
\text { (deg. N) }\end{array}$} & \multicolumn{8}{|c|}{$\begin{array}{l}\text { Maximum Water Level Above } \\
\text { Ground/Sea Level (meters) }\end{array}$} & \multicolumn{8}{|c|}{$\begin{array}{c}\text { Maximum Water Velocity, } \\
\text { (meters/second) }\end{array}$} \\
\hline & & & & \multicolumn{8}{|c|}{ Scenario } & \multicolumn{8}{|c|}{ Scenario } \\
\hline & & & & 1 & 2 & 3 & 4 & 6 & 7 & 9 & 10 & 1 & 2 & 3 & 4 & 6 & 7 & 9 & 10 \\
\hline 1 & $\mathrm{~s}$ & -148.0250655 & 60.0654076 & 3.2 & 2.7 & 2.7 & 2.7 & 1.3 & 0.8 & 1.0 & 13.9 & 2.2 & 2.2 & 1.8 & 2.1 & 0.5 & 0.4 & 0.4 & 1.3 \\
\hline 2 & 0 & -147.9961738 & 60.0714796 & 3.1 & 2.2 & 1.7 & 2.2 & 1.6 & 0.9 & 1.2 & 12.3 & 2.8 & 2.3 & 2.3 & 2.3 & 0.2 & 0.2 & 0.2 & 4.3 \\
\hline 3 & 0 & -148.0001216 & 60.0685153 & 1.8 & 1.6 & 1.4 & 1.7 & 1.4 & 0.8 & 1.1 & 11.6 & 2.8 & 3.6 & 3.2 & 3.6 & 0.9 & 0.7 & 0.6 & 6.5 \\
\hline 4 & $\mathrm{~S}$ & -148.0146972 & 60.0651139 & 0.0 & 0.0 & 0.0 & 0.0 & 0.0 & 0.0 & 0.0 & 2.8 & 0.0 & 0.0 & 0.0 & 0.0 & 0.0 & 0.0 & 0.0 & 2.9 \\
\hline 5 & $\mathrm{~s}$ & -148.0176479 & 60.0637752 & 1.0 & 0.8 & 0.5 & 0.8 & 0.0 & 0.0 & 0.0 & 8.9 & 3.3 & 2.2 & 2.6 & 2.2 & 0.0 & 0.0 & 0.0 & 5.4 \\
\hline 6 & $\mathrm{~S}$ & -148.0154349 & 60.0637752 & 3.8 & 3.2 & 3.3 & 3.2 & 0.8 & 0.4 & 0.5 & 12.2 & 3.1 & 2.8 & 3.5 & 3.9 & 0.6 & 0.5 & 0.8 & 3.0 \\
\hline 7 & 0 & -148.0497498 & 60.0262979 & 1.6 & 1.1 & 0.9 & 1.1 & 1.1 & 0.9 & 1.0 & 12.3 & 0.8 & 3.3 & 1.3 & 3.1 & 0.7 & 0.9 & 1.3 & 5.3 \\
\hline 8 & 0 & -148.0067879 & 60.1045172 & 1.2 & 2.3 & 0.3 & 3.2 & 1.1 & 1.2 & 1.1 & 11.0 & 1.5 & 1.3 & 1.4 & 1.3 & 0.2 & 0.4 & 0.3 & 3.1 \\
\hline 9 & 0 & -147.9660526 & 60.0356279 & 1.4 & 0.8 & 0.4 & 1.0 & 1.1 & 0.7 & 0.9 & 7.6 & 0.6 & 1.0 & 0.5 & 1.1 & 0.4 & 0.3 & 0.5 & 3.2 \\
\hline 10 & $\mathrm{~S}$ & -148.0196286 & 60.0637752 & 0.1 & 0.0 & 0.0 & 0.0 & 0.0 & 0.0 & 0.0 & 8.6 & 0.0 & 0.0 & 0.0 & 0.0 & 0.0 & 0.0 & 0.0 & 3.9 \\
\hline 11 & $\mathrm{~S}$ & -148.0016106 & 60.0739999 & 0.0 & 0.0 & 0.0 & 0.0 & 0.0 & 0.0 & 0.0 & 6.4 & 0.0 & 0.0 & 0.0 & 0.0 & 0.0 & 0.0 & 0.0 & 4.1 \\
\hline 12 & $\mathrm{~S}$ & -148.0001216 & 60.0771077 & 0.0 & 0.0 & 0.0 & 0.0 & 0.0 & 0.0 & 0.0 & 5.8 & 0.0 & 0.0 & 0.0 & 0.0 & 0.0 & 0.0 & 0.0 & 7.2 \\
\hline 13 & $\mathrm{~S}$ & -148.0097522 & 60.0637752 & 1.0 & 0.7 & 0.5 & 0.7 & 0.0 & 0.0 & 0.0 & 9.8 & 2.5 & 1.8 & 1.7 & 1.9 & 0.0 & 0.0 & 0.0 & 2.2 \\
\hline 14 & 0 & -148.0946924 & 60.0790338 & 1.8 & 1.0 & 0.8 & 1.7 & 1.2 & 1.3 & 1.1 & 8.6 & 0.5 & 3.2 & 1.4 & 3.4 & 1.0 & 0.7 & 1.6 & 5.0 \\
\hline 15 & $\mathrm{~S}$ & -148.0122247 & 60.0667395 & 0.0 & 0.0 & 0.0 & 0.0 & 0.0 & 0.0 & 0.0 & 0.0 & 0.0 & 0.0 & 0.0 & 0.0 & 0.0 & 0.0 & 0.0 & 0.0 \\
\hline 16 & 0 & -148.0176479 & 60.0587413 & 1.4 & 0.9 & 0.9 & 1.2 & 1.3 & 0.9 & 1.0 & 12.3 & 0.6 & 0.9 & 0.5 & 1.2 & 0.3 & 0.2 & 0.4 & 3.2 \\
\hline 17 & 0 & -148.0554325 & 60.0488170 & 2.1 & 2.5 & 1.0 & 3.0 & 1.7 & 1.5 & 1.4 & 16.7 & 0.8 & 0.7 & 0.6 & 0.7 & 0.2 & 0.2 & 0.2 & 1.7 \\
\hline 18 & 0 & -148.0169102 & 60.0628872 & 3.1 & 2.6 & 2.7 & 2.6 & 1.3 & 0.9 & 1.0 & 12.5 & 2.6 & 2.3 & 1.9 & 2.3 & 0.3 & 0.2 & 0.5 & 2.8 \\
\hline 19 & $\mathrm{~s}$ & -148.0090145 & 60.0654076 & 2.1 & 2.0 & 2.0 & 2.0 & 1.3 & 0.8 & 0.9 & 11.2 & 6.0 & 5.0 & 4.1 & 5.0 & 0.7 & 0.6 & 0.8 & 3.8 \\
\hline 20 & 0 & -147.9569138 & 60.1265924 & 3.4 & 3.3 & 1.8 & 3.3 & 1.1 & 0.6 & 0.8 & 4.2 & 0.9 & 1.3 & 0.9 & 1.3 & 0.2 & 0.2 & 0.2 & 1.4 \\
\hline
\end{tabular}

Appendix A-3 displays the time series of the water level and velocity for some scenarios in the second group as well as for scenario 10 . Tsunami dynamics according to scenarios 7 and 8 are rather similar; for clarity we plotted only the results related to scenario 8 . The final sea level for scenario 10 is marked by a dashed line. Since scenarios 6,7 , and 9 produce negligibly small vertical ground displacement in Sawmill Bay, the final sea level for these scenarios is equal to the pre-earthquake level, and thus is not displayed on the figures. Analyses of the time series plots show that the water level oscillations continue for at least 12 hours, and these oscillations, if superimposed with the rising tide, can hypothetically produce inundation of low-lying areas during high tide. The numerical modeling results for scenario 10 predict a 10-12 m (33-39 ft) wave in Crab Bay, and a runup up to $14-15 \mathrm{~m}(46-49 \mathrm{ft})$ along the shoreline.

\section{SOURCES OF ERRORS AND UNCERTAINTIES}

The hydrodynamic model used to calculate propagation and runup of tsunami waves is a nonlinear, flux-formulated, shallow-water model (Nicolsky and others, 2011a). It passes the validation and verification tests required for models used in production of tsunami inundation maps (Synolakis and others, 2007; NTHMP, 2012).

The source mechanism remains the biggest unknown in the problem of tsunami modeling. Since the initial condition for the modeling is determined by the displacement of the ocean bottom, the largest source of error is the earthquake model. When the tsunami is generated in the vicinity of the coast, the direction of the incoming waves, their amplitudes and times of arrival are determined by the initial displacements of the ocean surface in the source area because the distance to the shore is too small for the waves to dissipate. Therefore, the near-field inundation modeling results are especially sensitive to the fine structure of the tsunami source. Although the current model is validated to simulate the hypothetical inundation, it does not take into account the wave dispersion and cannot explicitly model origination and development of bore-like waves. The modeling process is highly sensitive to errors when the complexity of the source function is combined with its proximity to the coastal zone.

During development of the tsunami inundation maps, a spatially averaged ground uplift/subsidence is assumed for the entire community of Chenega Bay. However, during a potential earthquake, soil compaction in areas of unconsolidated deposits in the coastal area might occur and the extent of the tsunami inundation could be farther landward. Finally, we mention that the horizontal resolution of the grid used for

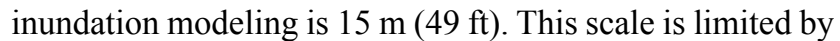
the resolution of the topographic and bathymetric data used for the grid construction. The $15 \mathrm{~m}(49 \mathrm{ft})$ resolution is high enough to describe major relief features; however, small topographic features, buildings, and other facilities cannot be accurately resolved by the existing model. 


\section{SUMMARY}

We present the results of numerical modeling of earthquake-generated tsunamis for the Sawmill Bay area and community of Chenega Bay, Alaska. Scenario 10 represents the worst-case scenario for the community of Chenega Bay. We note that although the occurrence of a Tohoku-type event is possible, the available geologic evidence suggests that repeated 1964-type events are a more realistic estimate of future earthquake displacements. The maps showing the results of our modeling have been completed using the best information available and are believed to be accurate, however, their preparation required many assumptions. We described several tectonic scenarios and provide an estimate of maximum credible tsunami inundation. Actual conditions during a tsunami event may vary from those considered, so the accuracy cannot be guaranteed. The limits of inundation shown should be used only as a guideline for emergency planning and response action. Actual areas inundated will depend on specifics of the earth deformations, on-land construction, and tide level, and they may differ from areas shown on the map. The information on this map is intended to provide a basis for state and local agencies to plan emergency evacuation and tsunami response actions in the event of a major tsunamigenic earthquake. These results are not intended for land-use regulation or building-code development.

\section{ACKNOWLEDGMENTS}

This project was supported by the National Oceanic and Atmospheric Administration (NOAA) under Reimbursable Service Agreement ADN 0931000 with the State of Alaska's Division of Homeland Security and Emergency Management. Some of the research in this publication is sponsored by the Cooperative Institute for Alaska Research with funds from the NOAA under cooperative agreement NA08OAR4320751 with the University of Alaska. Numerical calculations for this work were supported by a grant of High Performance Computing (HPC) resources from the Arctic Region Supercomputing Center (ARSC) at the University of Alaska Fairbanks. We thank Natalia Ruppert and Rod Combellick for providing valuable contributions to discussions on crustaland subduction-type tsunamigenic earthquakes, and Jacob Stroh for proofreading the manuscript. Reviews by Peter J. Haeussler and William Knight improved the report and maps.

\section{REFERENCES CITED}

Alaska Division of Community and Regional Affairs (DCRA), 2012, Chenega Bay Community Information: State of Alaska, Department of Commerce, Community, and Economic Development, Division of Community and Regional Affairs, Community Database Online. http:// commerce.alaska.gov/cra/DCRAExternal/community/ Details/68e5b39b-797a-442a-9e10-4a6d0ad4312f

Atwater, B.F., 1987, Evidence for great Holocene earthquakes along the outer coast of Washington State: Science, v. 236, p. $942-944$.
Atwater, B.F., Musumi-Rokkaku, Satoku, Satake, Kenji, Tsuji, Yoshinobu, Ueda, Kazue, and Yamaguchi, D.K., 2005, The orphan tsunami of 1700-Japanese clues to a parent earthquake in North America: U.S. Geological Survey Professional Paper 1707 (prepared in cooperation with the Geological Survey of Japan, the University of Tokyo, and the University of Washington, and published in association with University of Washington Press), $133 \mathrm{p}$.

Balay, S., Buschelman, K., Eijkhout, V., Gropp, W.D., Kaushik, D., Knepley, M.G., McInnes, L.C., Smith, B.F., and Zhang, H., 2004, PETSc users manual Tech. Rep. ANL-95/11, Revision 2.1.5: Argonne National Laboratory. http://www.mcs.anl.gov/petsc/

Berg, Eduard, Cox, D.C., Furumoto, A.S., Kajiura, Kinjiro, Kawasumi, Hirosi, and Shima, Etsuzo, 1970, Field survey of the tsunamis of 28 March 1964 in Alaska, and conclusions as to the origin of the major tsunami: Honolulu, University of Hawaii Institute of Geophysics, Technical Report HIG-70-2, $57 \mathrm{p}$.

Brocher, T.M., Fuis, G.S., Fisher, M.A., Plafker, George, Taber, J.J., and Christensen, N.I., 1994, Mapping the megathrust beneath the northern Gulf of Alaska using wide-angle seismic data: Journal of Geophysical Research, v. 99, p. 11,663-11,685.

Caldwell, R.J., Eakins, B.W., and Lim, E., 2009, Digital elevation models of Prince William Sound, Alaska-Procedures, data sources and analysis: Boulder, Colorado, National Geophysical Data Center, NOAA, 43 p. www. ngdc.noaa.gov/dem/report/download/1305

Carver, G.A., and Plafker, George, 2008, Paleoseismicity and neotectonics of the Aleutian subduction zone-An overview, in Freymueller, J.T., Haeussler, P.J., Wesson, R.L, and Ekström, G., eds., Active Tectonics and Seismic Potential of Alaska: American Geophysical Union Geophysical Monograph 179, p. 43-63.

Christensen, D.H., and Beck, S.L., 1994, The rupture process and tectonic implications of the Great 1964 Prince William Sound Earthquake: Pure and Applied Geophysics, v. 142 , no. 1 , p. $29-53$.

Coulter, H.W., and Migliaccio, R.R., 1966, Effects of the earthquake of March 27, 1964 at Valdez, Alaska: U.S. Geological Survey Professional Paper, 542-C, 36 p.

DeMets, Charles, Gordon, R.C., Argus, D.F., and Stein, Seth, 1990, Current plate motions: Geophysical Journal International, v. 101, no. 2, p. 425-478.

Doser, D.I., and Brown, W.A., 2001, A study of historic earthquakes of the Prince William Sound, Alaska, region: Bulletin of the Seismological Society of America, v. 91, no. 4, p. 842-857.

Dotsenko, S.F., and Soloviev, S.L., 1990, Comparative analysis of tsunami generation by 'piston' and 'membrane' bottom displacements: Tsunami research (in Russian), v. 4, p. 21-27.

Dutykh, D., Dias, F., Kervella, Y., 2006. Linear theory of wave generation by a moving bottom: Comptes Rendus Mathematique, v. 343, no. 7, p. 499-504.

Freund, L.B., and Barnett, D.M., 1976, A two-dimensional analysis of surface deformation due to dip-slip faulting: 
Bulletin of the Seismological Society of America, v. 66, p. 667-675.

Freymueller, J.T., Woodard, H., Cohen, S., Cross, R., Elliott, J., Larsen, C., Hreinsdottir, S., and Zweck, C., 2008, Active deformation processes in Alaska, based on 15 years of GPS measurements, in Freymueller, J.T., Haeussler, P.J., Wesson, R., and Ekstrom, G., eds., Active Tectonics and Seismic Potential of Alaska: Washington, D.C., American Geophysical Union Geophysical Monograph 179 , p. $1-42$.

Geist, E.L., and Dmowska, R., 1999, Local tsunamis and distributed slip at the source: Pure and Applied Geophysics, v. 154, p. 485-512.

Gilpin, L.M., 1995, Holocene paleoseismicity and coastal tectonics of the Kodiak Islands, Alaska: Santa Cruz, California, University of California, unpublished Ph.D. dissertation, $358 \mathrm{p}$.

Goto, C., Ogawa, Y., Shuto, N., and Imamura, F., 1997, Numerical method of tsunami simulation with the leap-frog scheme: UNESCO, IUGG/IOC TIME Project, Manuals and Guides 35.

Hamilton, Sarah, and Shennan, Ian, 2005, Late Holocene great earthquakes and relative sea-level change at Kenai, southern Alaska: Journal of Quaternary Science, v. 20, no. 2, p. 95-111.

Holdahl, S.R., and Sauber, Jeanne, 1994, Coseismic slip in the 1964 Prince William Sound earthquake-A new geodetic inversion: Pure and Applied Geophysics, v. 142, no. 1, p. 55-82.

Ichinose, Gene, Somerville, Paul, Thio, H.K., Graves, Robert, and O'Connell, Dan, 2007, Rupture process of the 1964 Prince William Sound, Alaska, earthquake from the combined inversion of seismic, tsunami, and geodetic data: Journal of Geophysical Research, v. 112, no. B7, p. 306, 21 p. doi: $10.1029 / 2006 J B 004728$

Iwasaki, S.I., 1982, Experimental study of a tsunami generated by a horizontal motion of a sloping bottom: Bulletin of the Earthquake Research Institute, University of Tokyo, v. 57 , p. 239-262.

Johnson, J.M., Satake, Kenji, Holdahl, S.R., and Sauber, Jeanne, 1996, The 1964 Prince William Sound earthquake-Joint inversion of tsunami waveforms and geodetic data: Journal of Geophysical Research, v. 101, no. B1, p. 523-532.

Kachadoorian Reuben, 1965, Effects of the earthquake of March 27, 1964, at Whittier, Alaska: U.S. Geological Survey Professional Paper 542-B, p. B1-B21, 3 sheets, scale $1: 4,800$.

Kajiura, Kinjiro, 1970, Tsunami source, energy, and the directivity of wave radiation: Tokyo, University of Tokyo, Bulletin of the Earthquake Research Institute, v. 48, part 5, p. 835-869.

Kervella, Y., Dutykh, D., and Dias, F., 2007, Comparison between three-dimensional linear and nonlinear tsunami generation models: Theoretical and Computational Fluid Dynamics, v. 21, p. 245-269.

Kowalik, Zygmunt, and Proshutinsky, A., 2010, Tsunami tide interactions-A Cook Inlet case study: Continental Shelf Research, v. 30, p. 633-642.
Kowalik, Zygmunt, Proshutinsky, T., and Proshutinsky, A., 2006, Tide-tsunami interactions: Science of Tsunami Hazards, v. 24, p. 242-256.

Kulikov, E.A., Rabinovich, A.B., Fine, I.V., Bornhold, B.D., and Thomson, R.E., 1998, Tsunami generation by landslides at the Pacific coast of North America and the role of tides: Oceanology, v. 38, no. 3, p. 323-328.

Lander, J.F., 1996, Tsunamis affecting Alaska, 1737-1996: Boulder, Colorado, National Geophysical Data Center (NGDC), NOAA, Key to Geophysical Research Documentation, v. 31, 195 p.

Leica Geosystems AG, 2002, GPS user manual, version 4: Heerbrugg, Switzerland, Leica Geosystems AG, 62 p.

Lemke, R.W., 1967, Effects of the earthquake of March 27, 1964, at Seward, Alaska: U.S. Geological Survey Professional Paper 542-E, 43 p., 2 sheets, scale 1:63,360.

Levin, Boris, and Nosov, Mikhail, 2008, Physics of Tsunamis: Newark, NJ, Springer, 327 p.

Liberty, L.M., Finn, S.P., Haeussler, P.J., Pratt, T.L., and Peterson, A., 2013, Megathrust splay faults at the focus of the Prince William Sound asperity, Alaska: Journal of Geophysical Research, Solid Earth, v. 118, p. 5,4285,441. doi:10.1002/jgrb.50372

Lim, E., Eakins, B.W., and Wigley, R., 2009, Southern Alaska coastal relief model-Procedures, data sources, and analysis: National Geophysical Data Center, NOAA, 25 p. http://www.ngdc.noaa.gov/mgg/coastal/s alaska.html

Miller, D.J., 1960, Giant waves in Lituya Bay, Alaska: U.S. Geological Survey Professional Paper 354-C, p. 51-86, 1 sheet, scale 1:50,000.

Nagao, R., Inoue, S., and Ohmachi, Tatsuo, 2010, Tsunami simulation considering horizontal dynamic displacement of the seabed: Journal of Japan Society of Civil Engineers, v. 66, p. 301-305.

National Geophysical Data Center/World Data Center (NGDC/WDC) Global Historical Tsunami Database, Boulder, CO, USA. http://www.ngdc.noaa.gov/hazard/ tsu db.shtml

National Tsunami Hazard Mapping Program (NTHMP), 2010, Guidelines and best practices for tsunami inundation modeling for evacuation planning: NTHMP Mapping \& Modeling Subcommittee, NOAA.

National Tsunami Hazard Mapping Program (NTHMP), 2012, Proceedings and results of the 2011 NTHMP model benchmarking workshop: Boulder, U.S. Department of Commerce/NOAA/NTHMP, NOAA Special Report, 436 p. http://nthmp.tsunami.gov

Nicolsky, D.J., 2012, Alaska tsunami model, in Proceedings and Results of the 2011 NTHMP Model Benchmarking Workshop: Boulder, U.S. Department of Commerce/ NOAA/NTHMP; (NOAA Special Report), p. 55-87. http://nthmp.tsunami.gov

Nicolsky, D.J., Suleimani, E.N., and Hansen, R.A., 2011a, Validation and verification of a numerical model for tsunami propagation and runup: Pure and Applied Geophysics, v. 168, p. 1,199-1,222. doi:10.1007/s00024010-0231-9

Nicolsky, D.J., Suleimani, E.N., Combellick, R.A., and Hansen, R.A., 2011b, Tsunami inundation maps of Whittier 
and western Passage Canal, Alaska: Alaska Division of Geological \& Geophysical Surveys Report of Investigation 2011-7, 65 p. doi:10.14509/23244

Nicolsky, D.J., Wolken, G.J., Combellick, R.A., and Hansen, E., 2011c, APPENDIX B: Potential rockfall-generated tsunami at Whittier, Alaska, in Nicolsky, D.J., Suleimani, E.N., Combellick, R.A., and Hansen, R.A., Tsunami inundation maps of Whittier and western Passage Canal, Alaska: Alaska Division of Geological \& Geophysical Surveys Report of Investigation 2011-7A, p. 57-65. doi:10.14509/23283

Nicolsky, D.J., Suleimani, E.N., and Hansen, R.A., 2012, Note on the 1964 Alaska tsunami generation by horizontal displacements of ocean bottom-Numerical modeling of the runup in Chenega Cove, Alaska: Pure and Applied Geophysics, published online. doi:10.1007/s00024012-0483-7

Nicolsky D.J., Suleimani, E.N., Haeussler, P.J., Ryan, H.F., Combellick, R.A., Koehler, R.D., and Hansen, R.A., 2013, Tsunami inundation maps of Port Valdez, Alaska: Alaska Division of Geological \& Geophysical Surveys Report of Investigations 2013-1, 79 p. doi:10.14509/25055

Nishenko, S.P., 1991, Circum-Pacific seismic potential, 1989-1999: Pure and Applied Geophysics, v. 135, p. 169-259.

Nishenko, S.P., and Jacob, K.H., 1990, Seismic potential of the Queen Charlotte-Alaska-Aleutian seismic zone: Journal of Geophysical Research, v. 95, no. B3, p. 2,511-2,532.

Ohta, Yusaku, Freymueller, J.T., Hreinsdottir, Sigrun, and Suito, Hisashi, 2006, A large slow slip event and the depth of the seismogenic zone in the south-central Alaska subduction zone: Earth and Planetary Science Letters, v. 247, p. 108-116. doi:10.1016/i.epsl.2006.05.013

Okada, Yoshimitsu, 1985, Surface deformation due to shear and tensile faults in a half-space: Bulletin of the Seismological Society of America, v. 75, no. 4, p. 1,135-1,154.

Okuda, Hiroshi, Nakajima, Kengo, Iizuka, Mikio, Chen, L., and Nakamura, Hisashi, 2003, Parallel finite element analysis platform for the Earth Simulator-GeoFEM, in Sloot, P.M.A., Abramson, D., Bogdanov, A.V., Dongarra, J.J., Zomaya, A.Y., and Gorbachev, Y.E., eds., Proceedings, 3rd International Conference on Computational Science, Melbourne, Australia, June 2003, Workshop on Computational Earthquake Physics and Solid Earth System Simulation: Springer, v. III of LNCS 2659, p. 773-780.

Page, R.A., Biswas, N.N., Lahr, J.C., and Pulpan, Hans, 1991, Seismicity of continental Alaska, in Slemmons, D.B., Engdahl, E.R., Zoback, M.D., and Blackwell, D.D., eds., Neotectonics of North America: Boulder, Colorado, Geological Society of America, Decade Map Volume 1, p. 47-68.

Parkin, E., 1966, Horizontal displacements, part 2 of Alaskan surveys to determine crustal movement: U.S. Coast and Geodetic Survey, Technical Report, 11 p.

Pelinovsky, Efrim, 1982, Nonlinear dynamics of tsunami waves: Gorky, Institute of Applied Physics Press, 226 p., in Russian.
Pelinovsky, Efrim, 1996, Tsunami wave hydrodynamics: Nizhny Novgorod, Institute of Applied Physics Press, 276 p., in Russian.

Plafker, George, 1967, Surface faults on Montague Island associated with the 1964 Alaska earthquake: U.S. Geological Survey Professional Paper 543-G, p. G1-G42.

Plafker, George, 1969, Tectonics: U.S. Geological Survey Professional Paper 543-I, p. G1-G74.

Plafker, George, and Thatcher, Wayne, 2008, Geological and geophysical evaluation of the mechanisms of the great 1899 Yakutat Bay earthquakes, in Freymueller, J.T., Haeussler, P.J., Wesson, R.L., and Ekström, Goran, eds., Active tectonics and seismic potential of Alaska: Geophysical Monograph 179, p. 215-236. doi:10.1029/179GM12

Plafker, George, Kachadoorian, Reuben, Eckel, E.B., and Mayo, L.R., 1969, Effects of the earthquake of March 27, 1964, on various communities: U.S. Geological Survey Professional Paper 542-G, 50 p.

Priest, G.R., Goldfinger, Chris, Wang, Kelin, Witter, R.C., Zhang, Yinglong, and Baptista, A.M., 2009, Confidence levels for tsunami-inundation limits in northern Oregon inferred from a 10,000-year history of great earthquakes at the Cascadia subduction zone: Natural Hazards, v. 54, no. 1. doi:10.1007/s11069-009-9453-5

Santini, S., Dragoni, M., and Spada, G., 2003, Asperity distribution of the 1964 Great Alaska Earthquake and its relation to subsequent seismicity in the region: Tectonophysics, v. 367, no. 3-4, p. 219-233.

Satake, Kenji, Shimazaki, Kunihiko, Tsuji, Yoshinobu, and Ueda, Kazue, 1996, Time and size of a giant earthquake in Cascadia inferred from Japanese tsunami records of January 1700: Nature, v. 379, no. 6562, p. 246-249.

Satake, Kenji, Wang, Kelin, and Atwater, B.F., 2003, Fault slip and seismic moment of the 1700 Cascadia earthquake inferred from Japanese tsunami descriptions: Journal of Geophysical Research, v. 108, no. B11, p. 2,535-2,551. doi:10.1029/2003JB002521

Shennan, Ian, Barlow, Natasha, and Combellick, R.A., 2008, Paleoseismological records of multiple great earthquakes in south-central Alaska-A 4,000 year record at Girdwood, in, Freymueller, J.T., Haeussler, P.J., Wesson, R.L, and Ekström, G., eds., Active Tectonics and Seismic Potential of Alaska: American Geophysical Union Geophysical Monograph 179, p. 185-199.

Shennan, Ian, Bruhn, Ronald, and Plafker, George, 2009, Multi-segment earthquakes and tsunami potential of the Aleutian megathrust: Quaternary Science Reviews, v. 28, no. 1-2, p. 7-13.

Shokin, Y.I., Chuborav, L.B., Novikov, V.A., and Sudakov, A.N., 1987, Calculations of tsunami travel time charts in the Pacific Ocean-Models algorithms, techniques, results: Science of Tsunami Hazards, v. 5, p. 85-113.

Sobolev, S.V., Babeyko, A.Y., Wang, R., Hoechner, A., Galas, R., Rothacher, M., Sein, D.V., Schröter, J., Lauterjung, J., and Subarya, C., 2007, Tsunami early warning using GPS-Shield arrays: Journal of Geophysical Research, v. 112, no. B8, p. 415. doi:10.1029/2006JB004640

Song, Y.T., Fu, L.-L., Zlotnicki, V., Ji, C., Hjorleifsdottir, V., Shum, C., and Yi, Yuchan, 2008, The role of horizontal 
impulses of the faulting continental slope in generating the 26 December 2004 tsunami: Ocean Modeling, v. 20, p. $362-379$.

Suito, Hisashi, and Freymueller, J.T., 2009, A viscoelastic and afterslip postseismic deformation model for the 1964 Alaska earthquake: Journal of Geophysical Research, v. 114, no. B11, p. 404-426. doi:10.1029/2008JB005954.

Suleimani, E.N., 2011, Numerical studies of tectonic and landslide-generated tsunamis caused by the 1964 Great Alaska Earthquake: Fairbanks, Alaska, University of Alaska Fairbanks Ph.D. thesis, 196 p.

Suleimani, E.N., Combellick, R.A., Marriott, Duncan, Hansen, R.A., Venturato, A.J., and Newman, J.C., 2005, Tsunami hazard maps of the Homer and Seldovia areas, Alaska: Alaska Division of Geological \& Geophysical Surveys Report of Investigations 2005-2, 28 p., 2 sheets, scale 1:12,500. doi:10.14509/14474

Suleimani, E.N., Hansen, R.A., Combellick, R.A., Carver, G.A., Kamphaus, R.A., Newman, J.C., and Venturato, A.J, 2002, Tsunami hazard maps of the Kodiak area, Alaska: Alaska Division of Geological \& Geophysical Surveys Report of Investigations 2002-1, 16 p., 4 sheets, scale 1:12,500. doi:10.14509/2860

Synolakis, C.E., and Bernard, E.N., 2006, Tsunami science before and beyond Boxing Day 2004, in Thompson, J.M.T., Heppert, H.E., and Sparks, R.S.J., eds., Extreme natural hazards: Philosophical Transactions of the Royal Society, Mathematical, Physical, and Engineering Sciences, v. 364, no. 1845 , p. 2,231-2,265.

Synolakis, C.E., Bernard, E.N., Titov, V.V., Kânoğlu, U., and González, F.I., 2007, Standards, criteria, and procedures for NOAA evaluation of tsunami numerical models: Seattle, NOAA/Pacific Marine Environmental Laboratory, Technical Memorandum OAR PMEL-135, 55 p.
Tanioka, Yuichiro, and Satake, Kenji, 1996, Tsunami generation by horizontal displacement of ocean bottom: Geophysical Research Letters, v. 23, no. 8, p. 861-864.

Titov, V.V., and Synolakis, C.E., 1995, Evolution and runup of breaking and nonbreaking waves using VTSC-2: Journal of Waterway, Port, Coastal, and Ocean Engineering, v. 121 , no. 6 , p. $308-316$.

Titov, V.V., and Synolakis, C.E., 1997, Extreme inundation flows during the Hokkaido-Nansei-Oki Tsunami: Geophysical Research Letters, v. 24, no. 11, p. 1,315-1,318.

Voit, S.S., 1987, Tsunamis: Annual Review of Fluid Mechanics, v. 19, no. 1, p. 217-236.

Wang, Kelin, Wells, R.E., Mazzotti, Stephane, Hyndman, R.D., and Sagiya, Takeshi, 2003, A revised dislocation model of interseismic deformation of the Cascadia subduction zone: Journal of Geophysical Research, v. 108, no. B1, p. 2,026-2,038. doi:10.1029/2001JB001227

Wilson, B.W., and Tørum, Alf, 1972, Effects of the tsunamis-An engineering study, in The Great Alaska Earthquake of 1964: Washington, D.C., National Academy of Sciences-Engineering, p. 361-526.

Witter, R.C., Zhang, Y., Wang, Kelin, Priest, G.R., Goldfinger, C., Stimely, L.L., English, J.T., and Ferro, P.A., 2011, Simulating tsunami inundation at Bandon, Coos County, Oregon, using hypothetical Cascadia and Alaska earthquake scenarios: Oregon Department of Geology and Mineral Industries Special Paper 43, 57 p. http://activetectonics.coas.oregonstate.edu/paper files/SP-43 print. pdf

Zweck, Chris, Freymueller, J.T., and Cohen, S.C., 2002, Three-dimensional elastic dislocation modeling of the postseismic response to the 1964 Alaska earthquake: Journal of Geophysical Research, v. 107, no. B4, 12 p. doi:10.1029/2001JB000409 


\section{APPENDIX A-1}

Locations of time series points in Sawmill Bay, as well as in Elrington, Latouche, and Prince of Wales passages (below), and near the community of Chenega Bay (next page; outlined in red). The longitude and latitude locations of the time series points are listed in table 4.

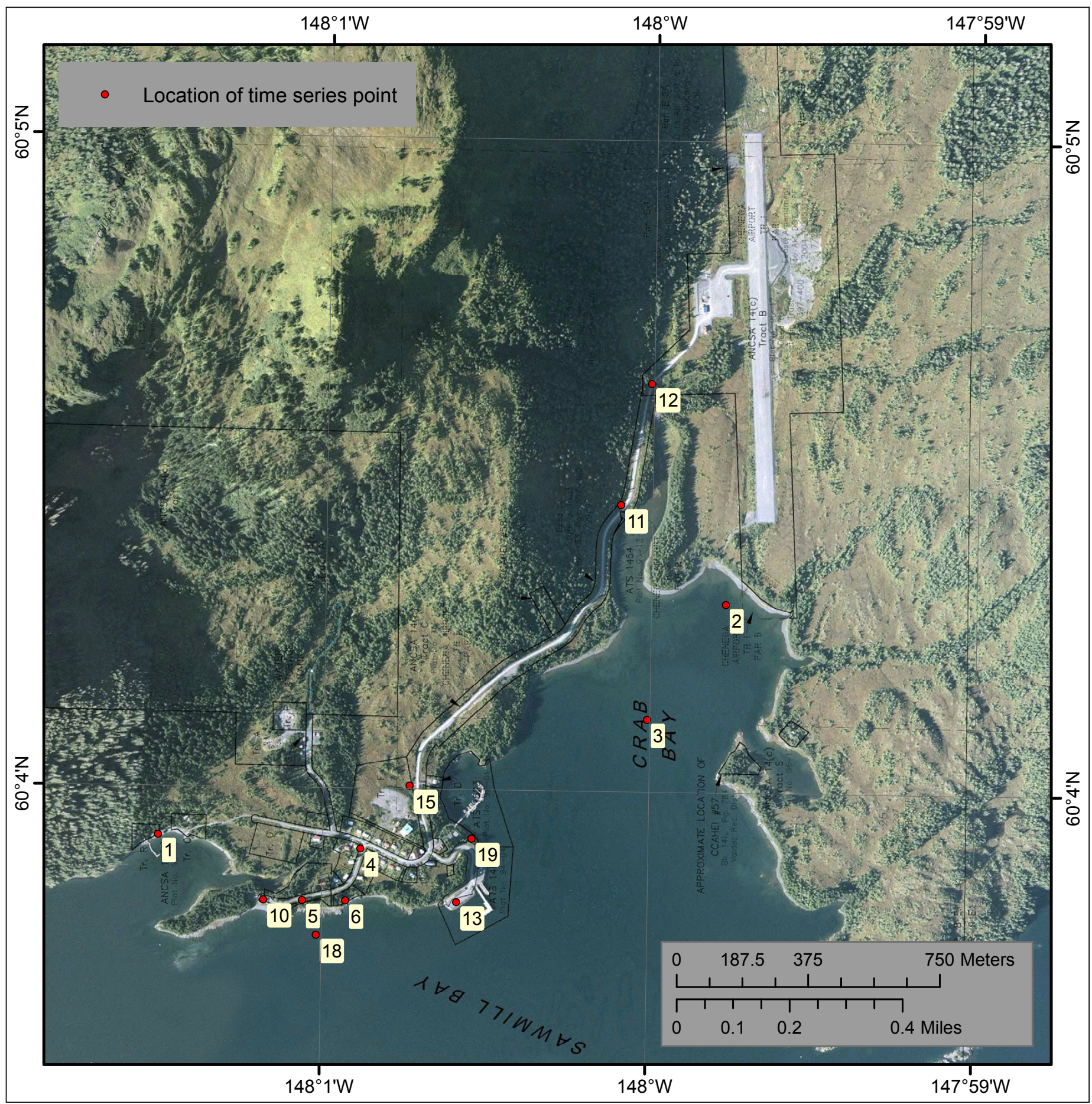


APPENDIX A-1 (CONT.)

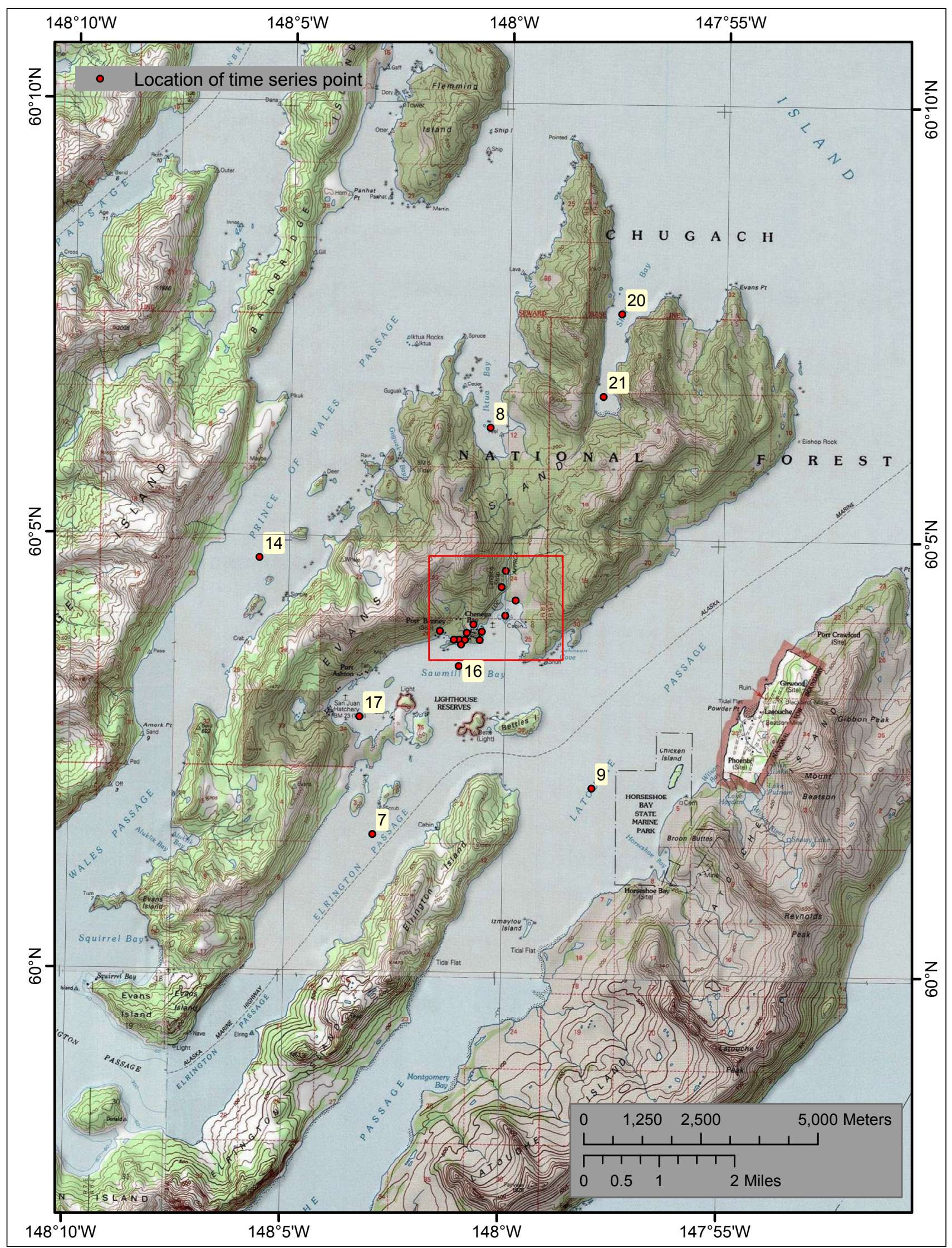




\section{APPENDIX A-2}

Time series of the water level (left column) and velocity (right column) at selected locations for scenarios 1-4. Elevations of onshore locations and the ocean depth at the offshore locations are given with respect to the pre-earthquake MHHW datum. The maximum water level and velocity for the above scenarios are listed in table 4.

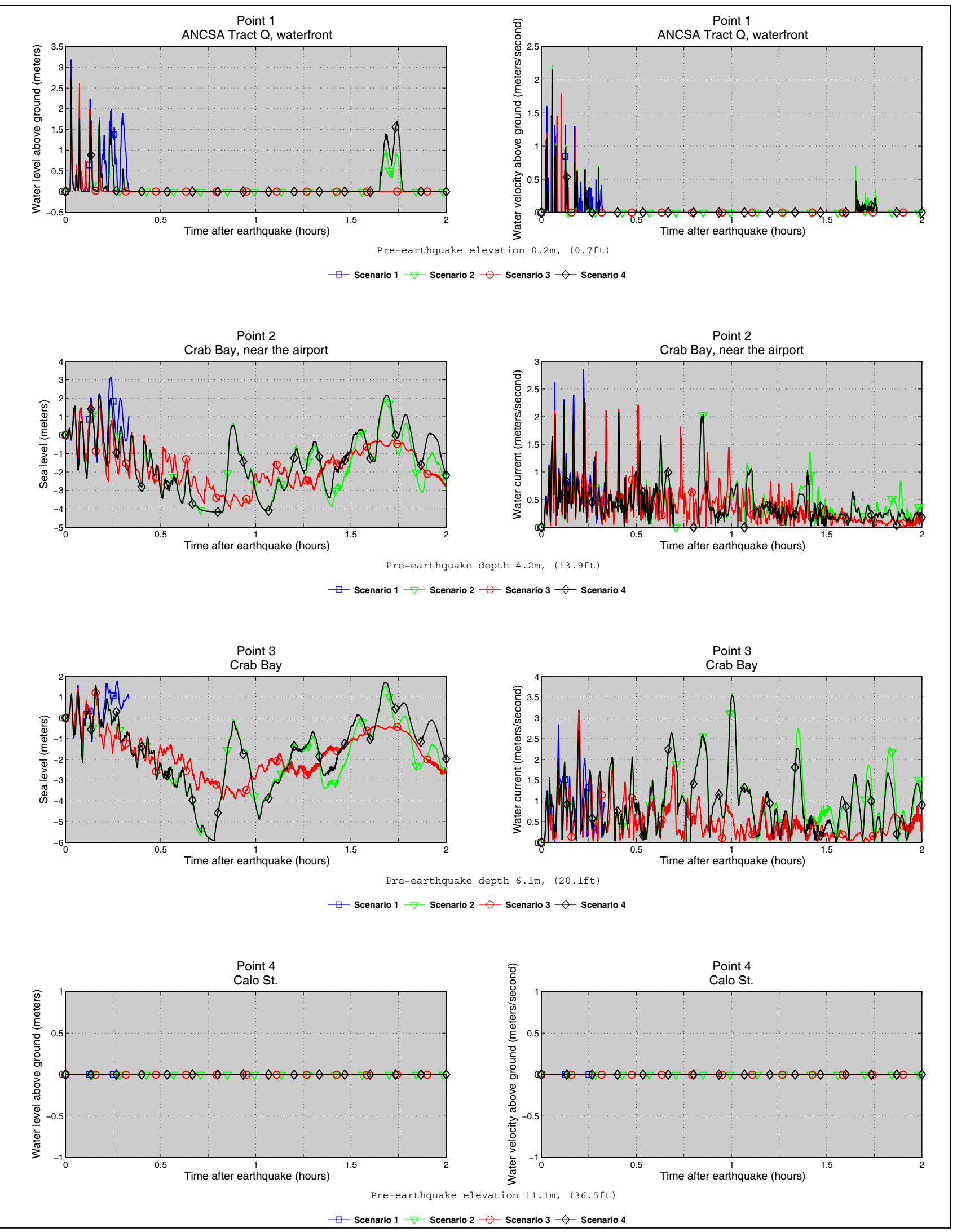




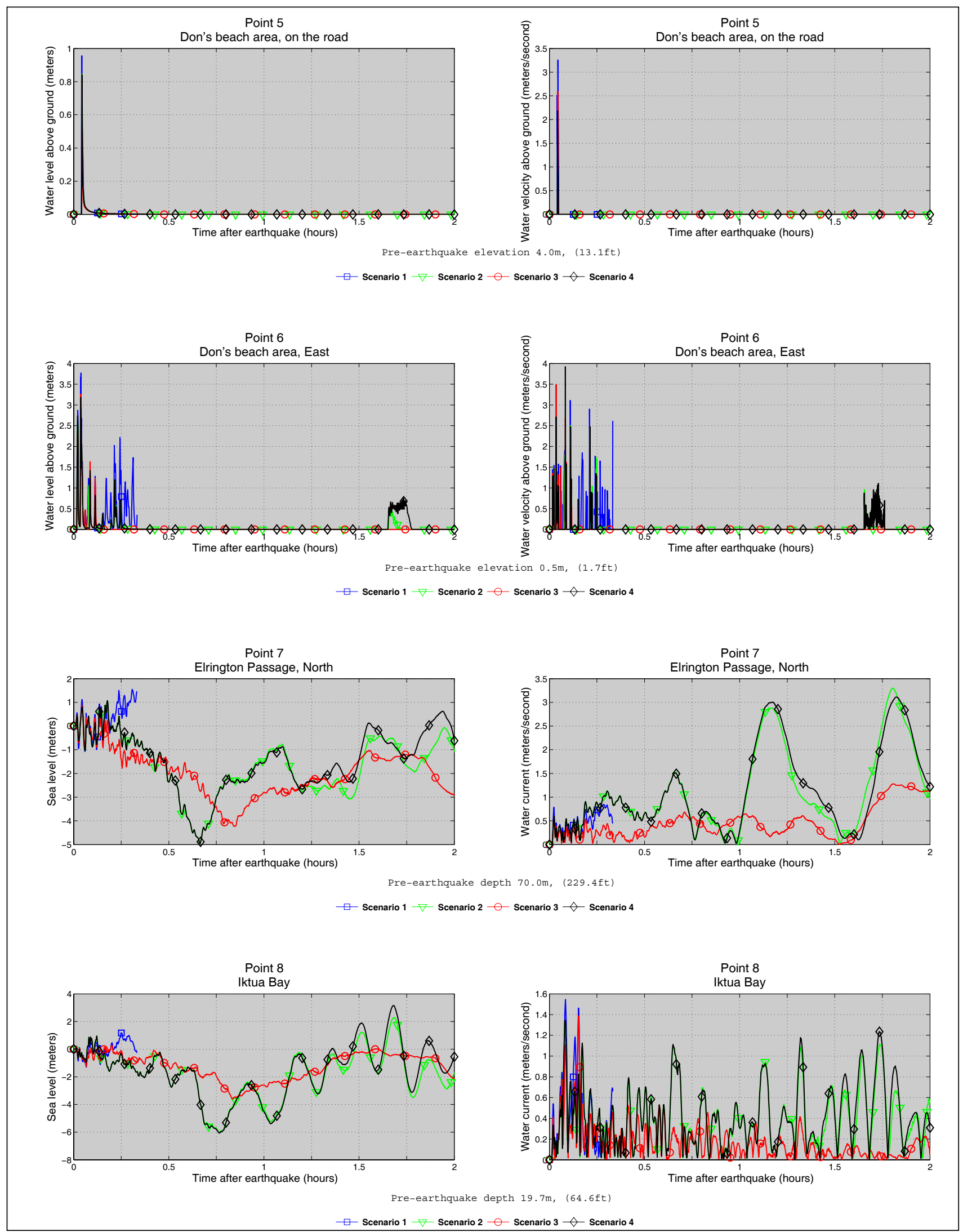




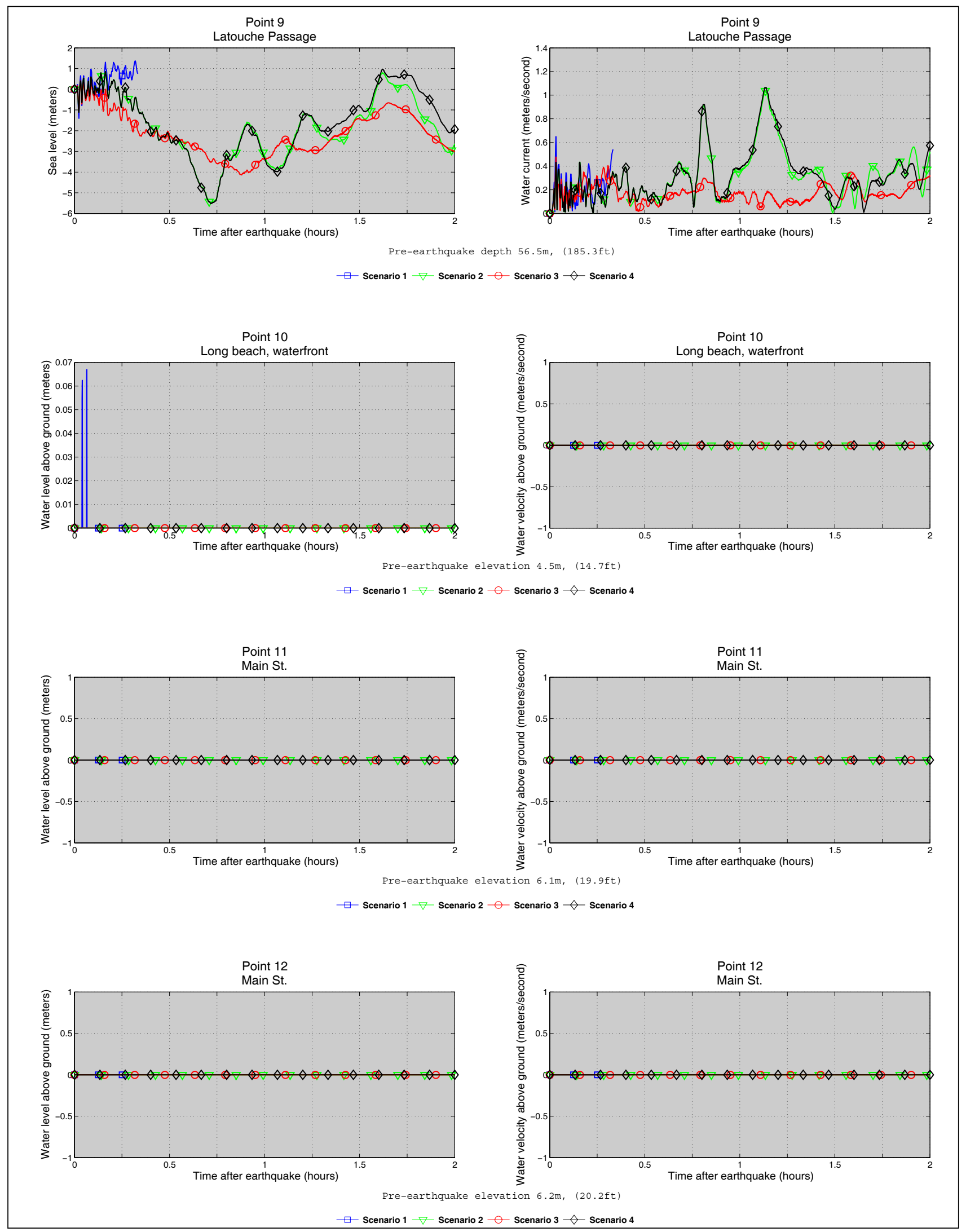




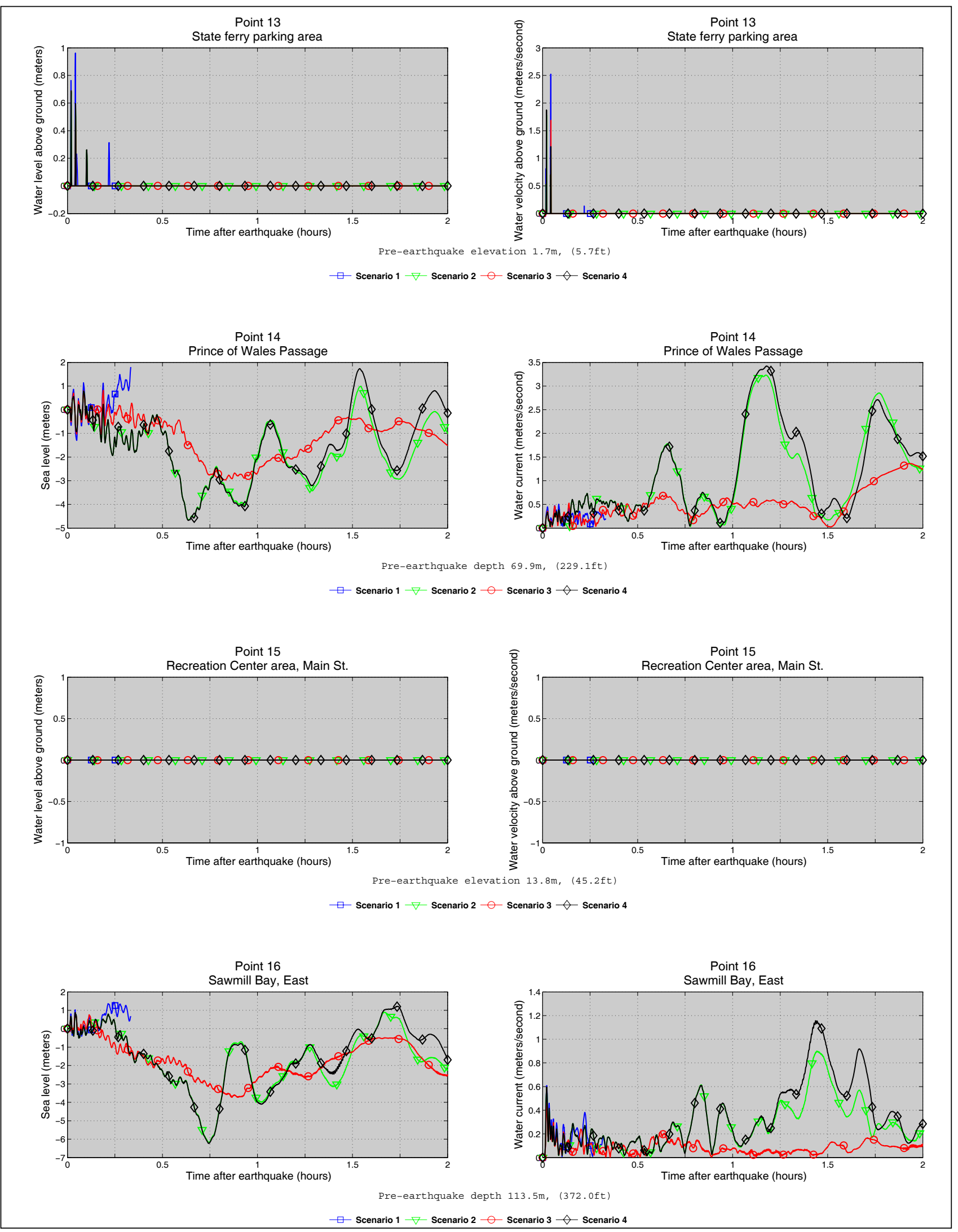



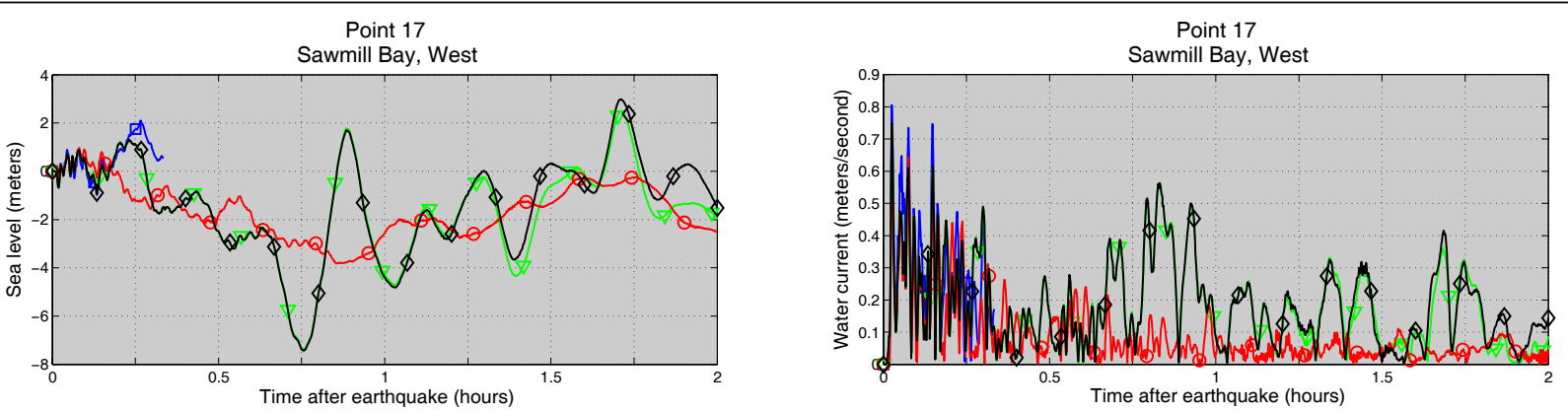

Pre-earthquake depth $24.9 \mathrm{~m},(81.8 \mathrm{ft})$

$\square$ Scenario $1-\nabla$ Scenario $2-$ Scenario $3-$ Scenario 4
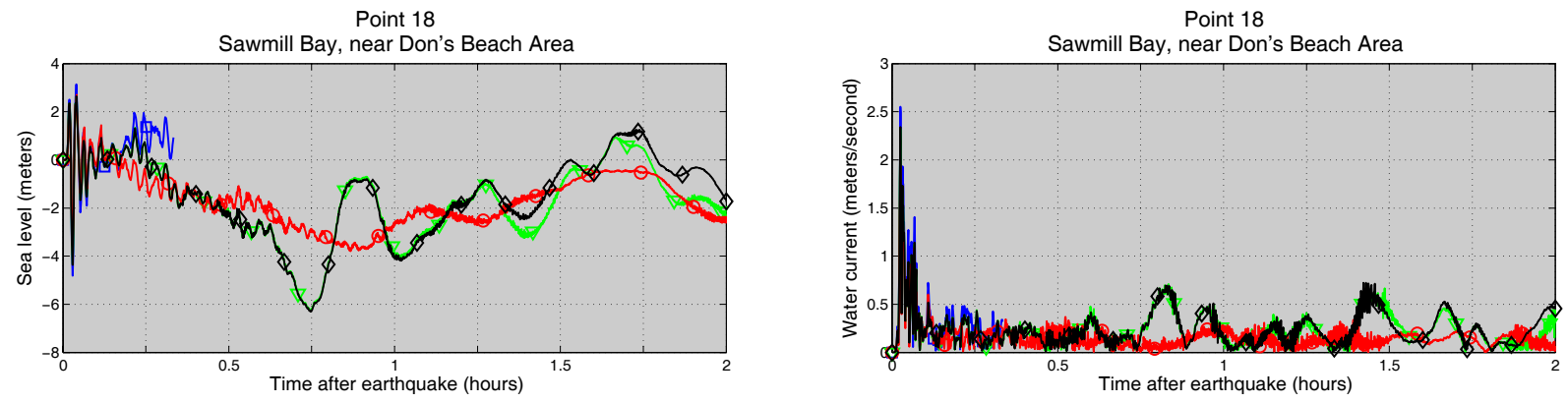

Pre-earthquake depth $11.6 \mathrm{~m},(38.0 \mathrm{ft})$

Point 19

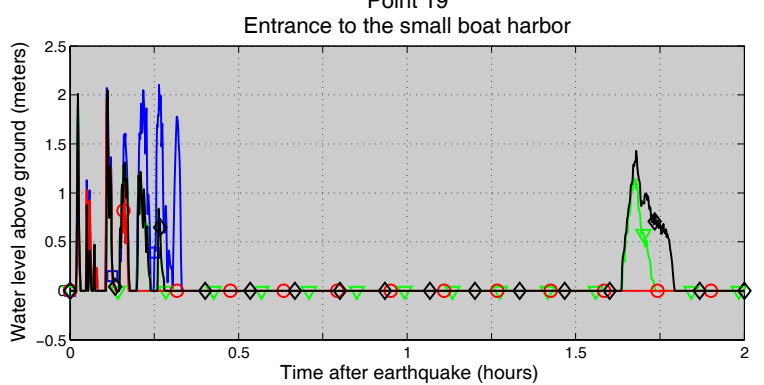

Pre-earthquake elevation $0.1 \mathrm{~m},(0.4 \mathrm{ft})$
Point 19

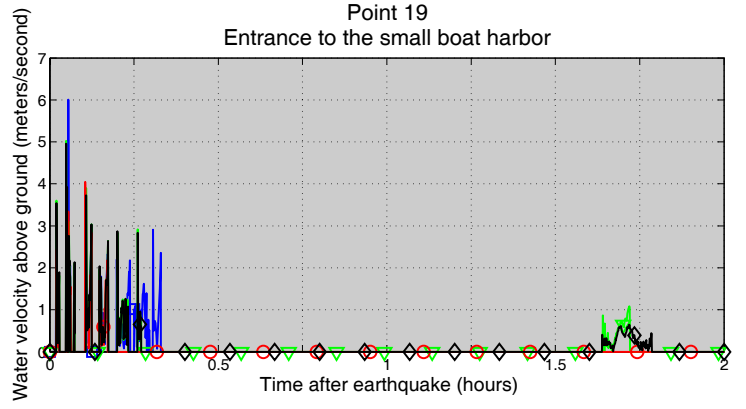

Scenario $3 \smile$ Scenario 4

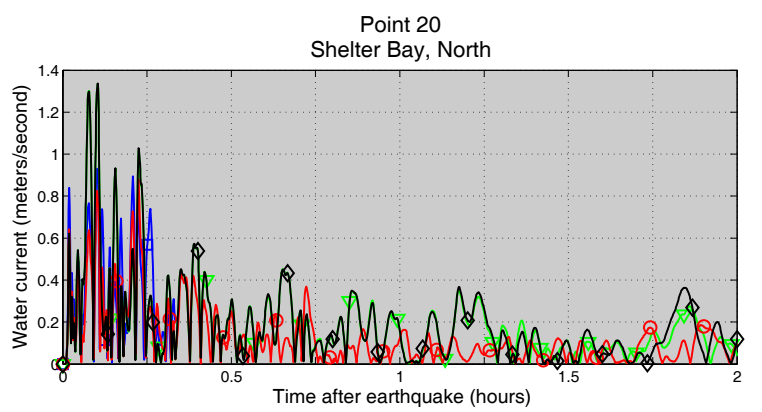

Time after earthquake (hours)

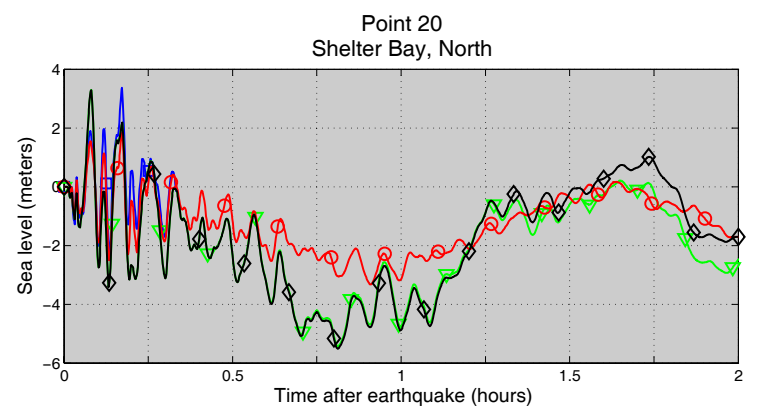

Pre-earthquake depth $81.4 \mathrm{~m},(266.9 \mathrm{ft}$ 


\section{APPENDIX A-3}

Time series of water level (left column) and velocity (right column) at selected locations for scenarios 6, 7, 9, and 10. Elevations of onshore locations and the ocean depth at the offshore locations are given with respect to the pre-earthquake MHHW datum. The maximum water level and velocity for the above scenarios are listed in table 4.

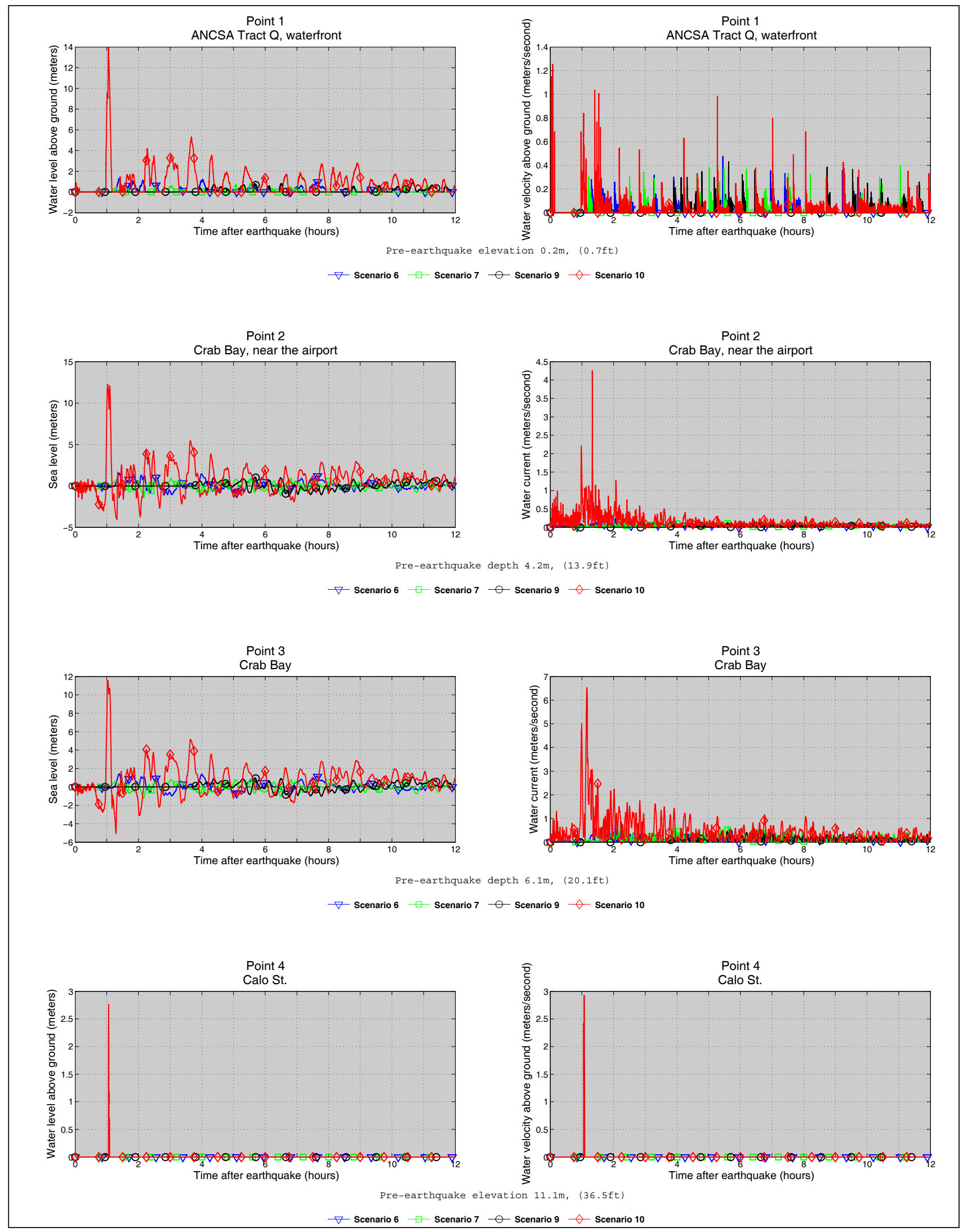



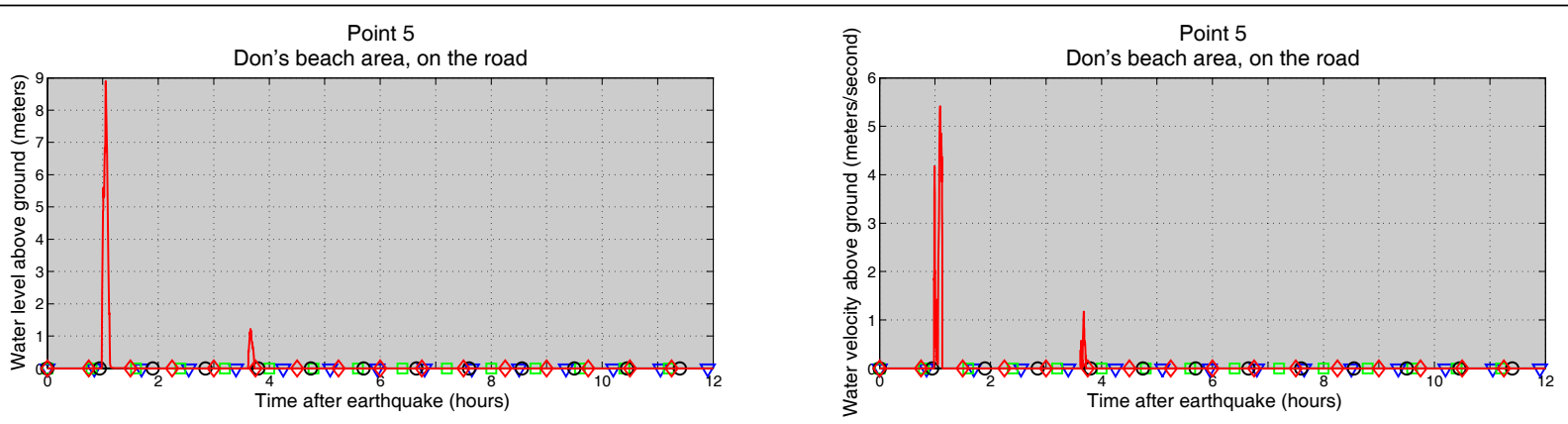

Pre-earthquake elevation $4.0 \mathrm{~m},(13.1 \mathrm{ft})$

$\nabla$ Scenario $6-$ Scenario $7-\odot$ Scenario $9 \multimap$ Scenario 10

Point 6

Don's beach area, East

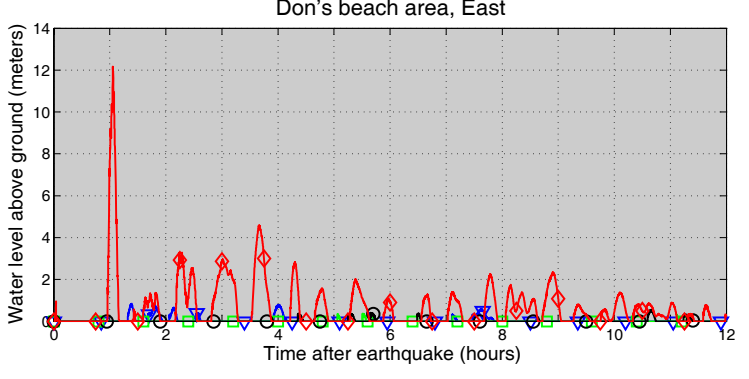

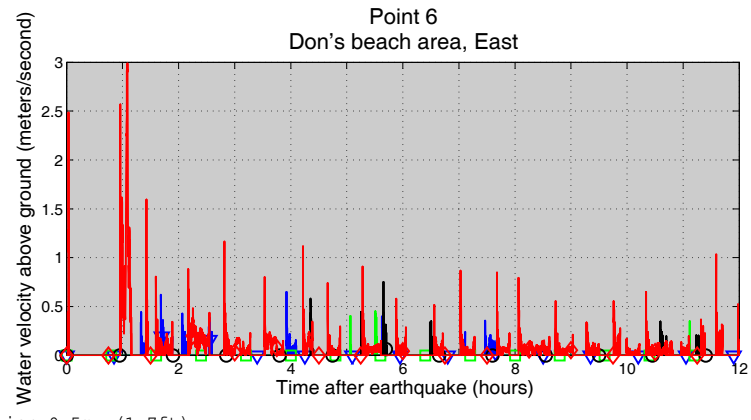

$\nabla$ Scenario $6 \square$ Scenario $7-\odot$ Scenario $9 \triangleleft$ Scenario 10
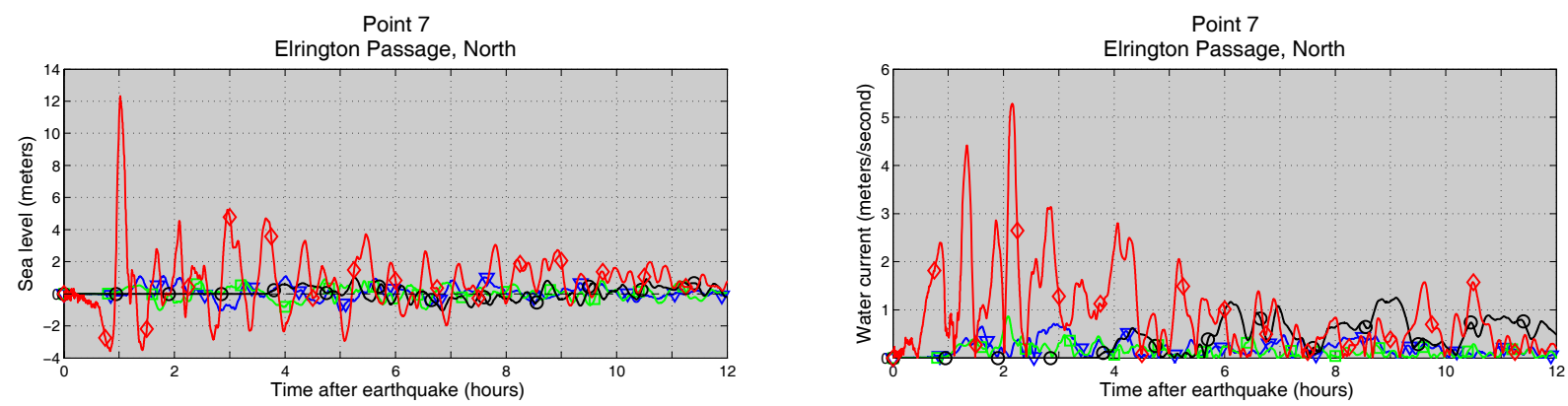

Pre-earthquake depth $70.0 \mathrm{~m},(229.4 \mathrm{ft})$

$\nabla$ Scenario $6 \square$ Scenario $7-$ Scenario $9 \diamond$ Scenario 10
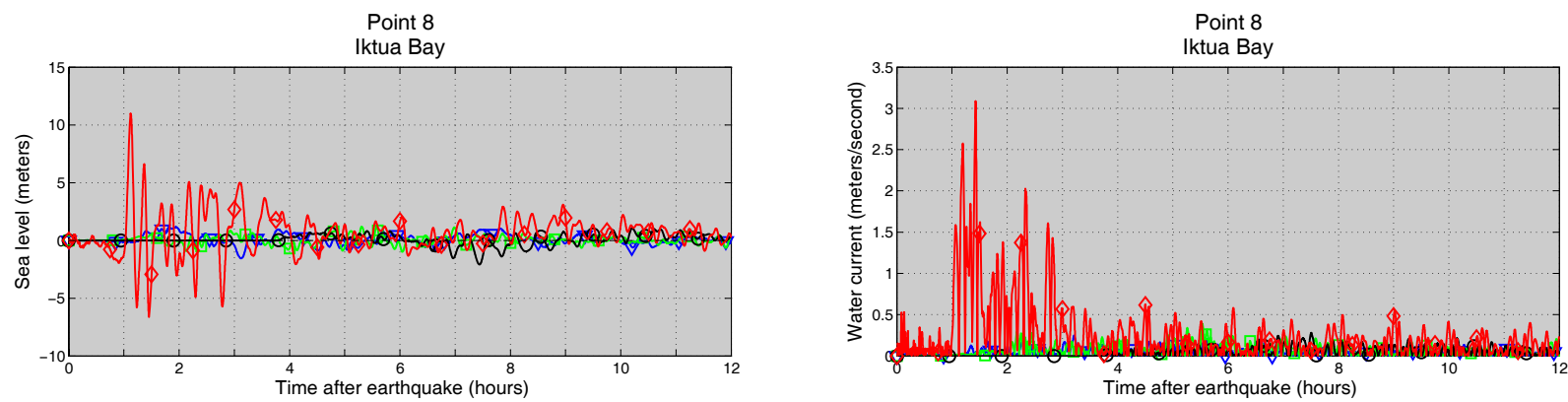

Pre-earthquake depth $19.7 \mathrm{~m},(64.6 \mathrm{ft})$ 


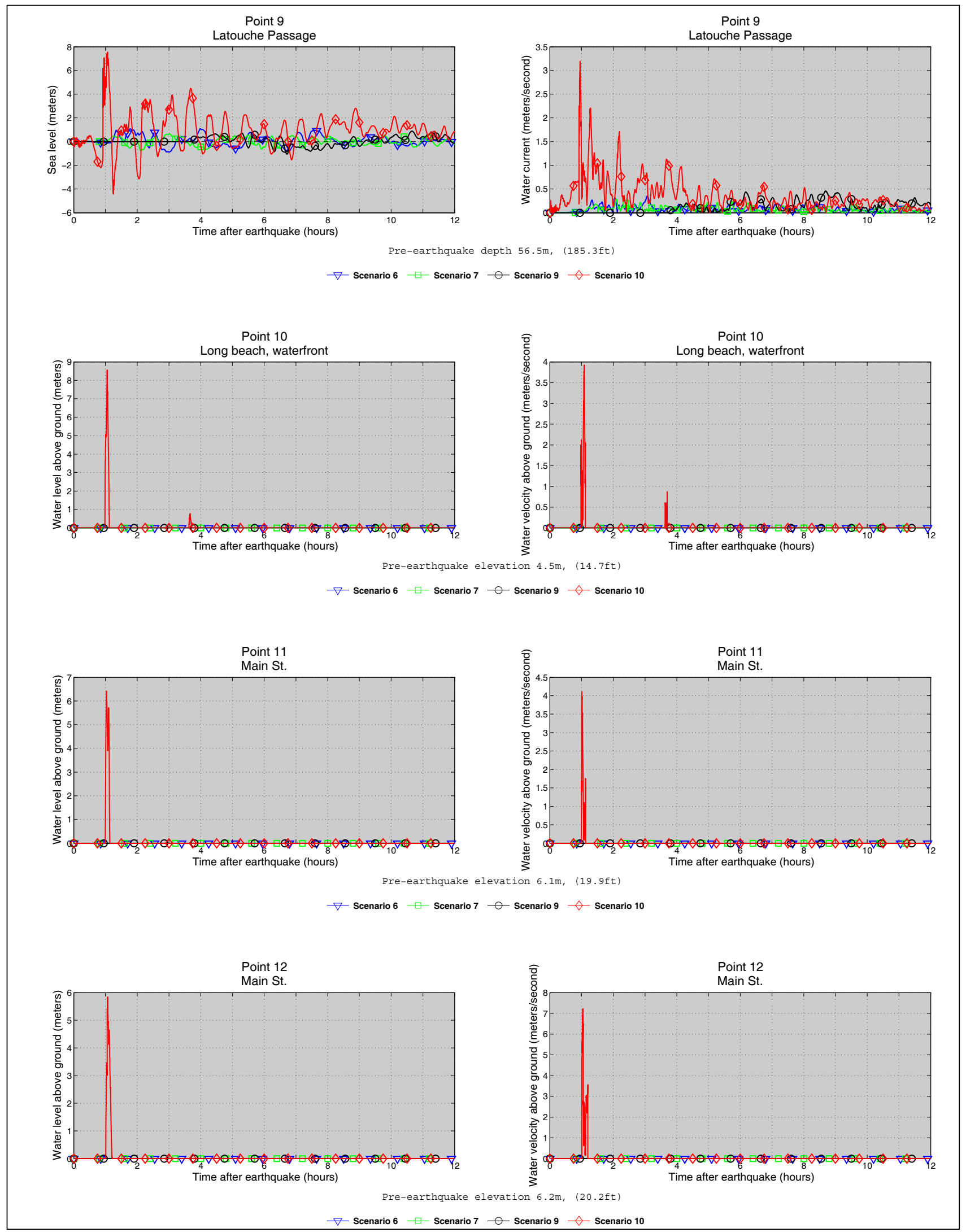




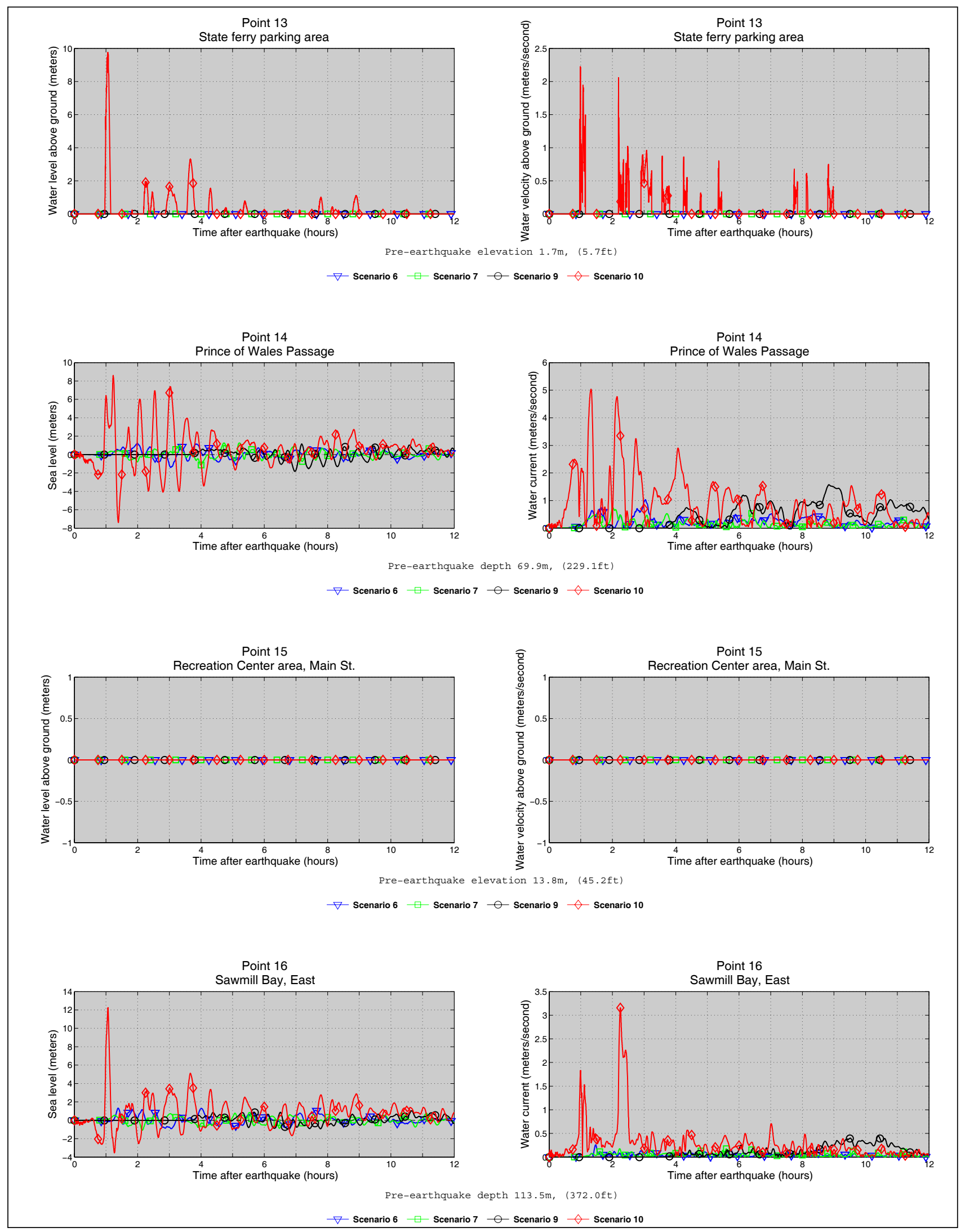



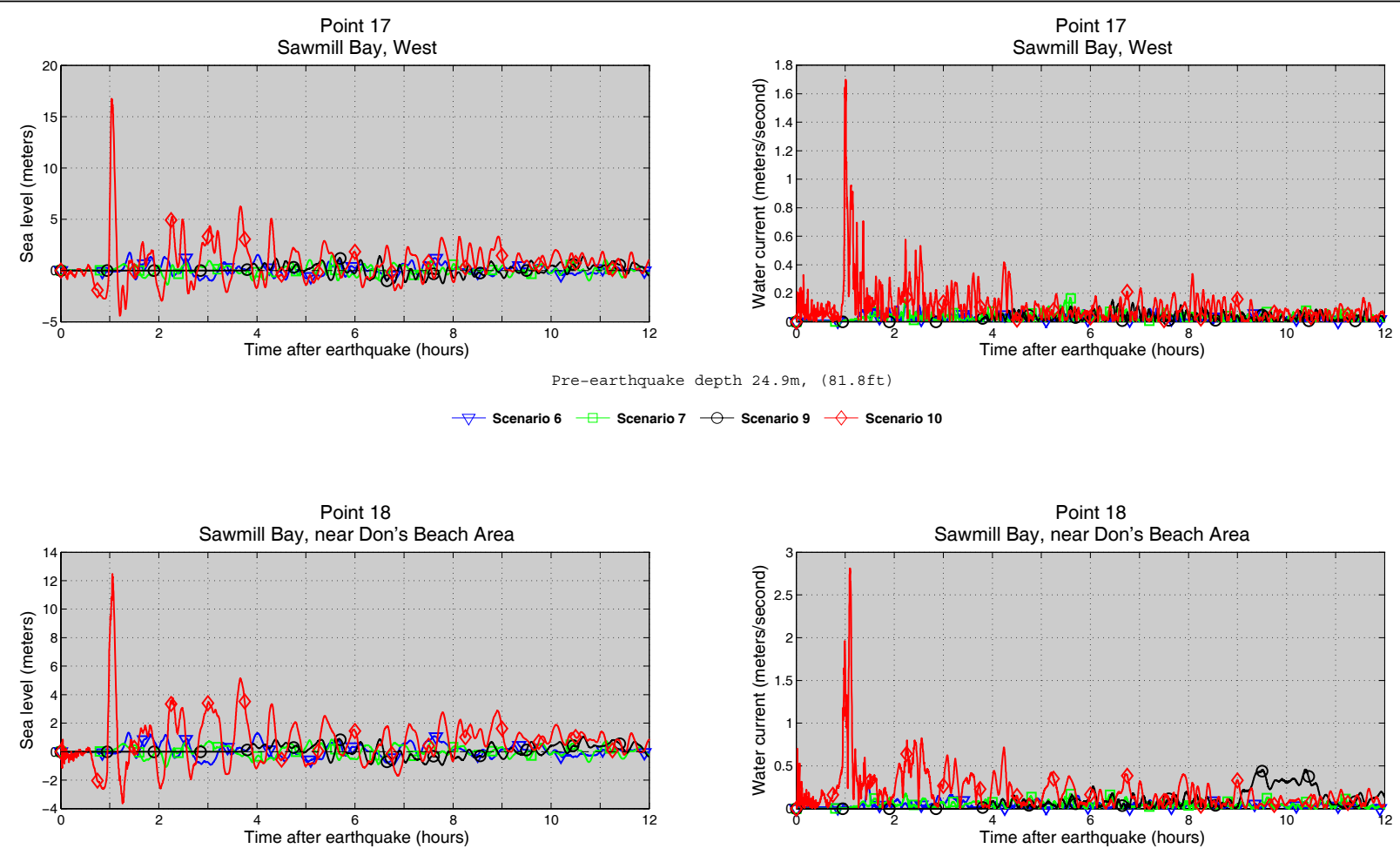

$\nabla$ Scenario $6 \square$ Scenario $7-\odot$ Scenario $9 \triangleleft$ Scenario 10

Point 19

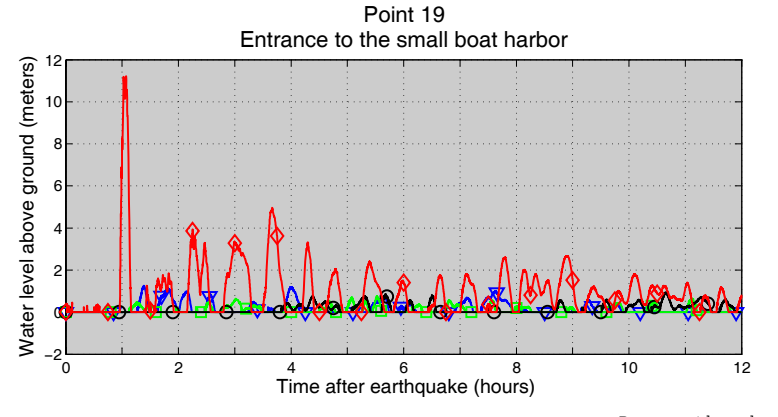

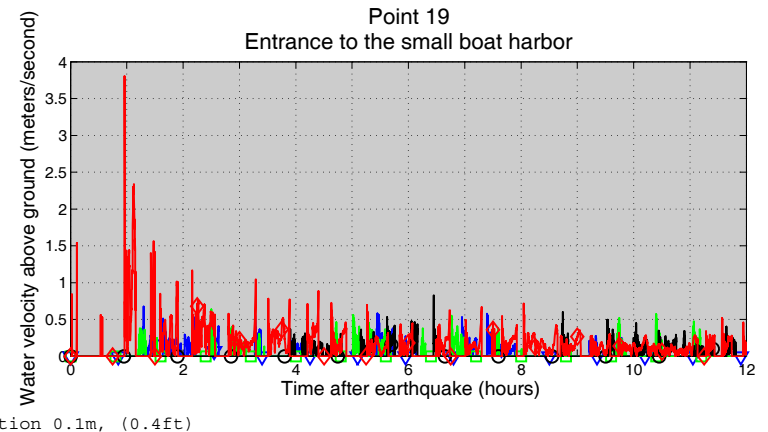

$\nabla$ Scenario $6 \square$ Scenario $7-$ Scenario $9 \triangleleft$ Scenario 10

Point 20

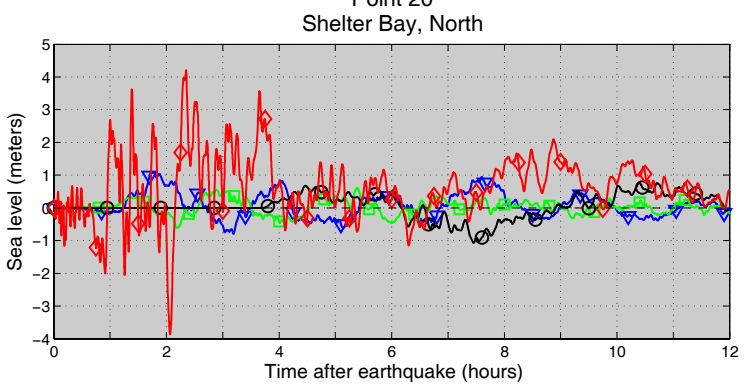

Point 20

Shelter Bay, North

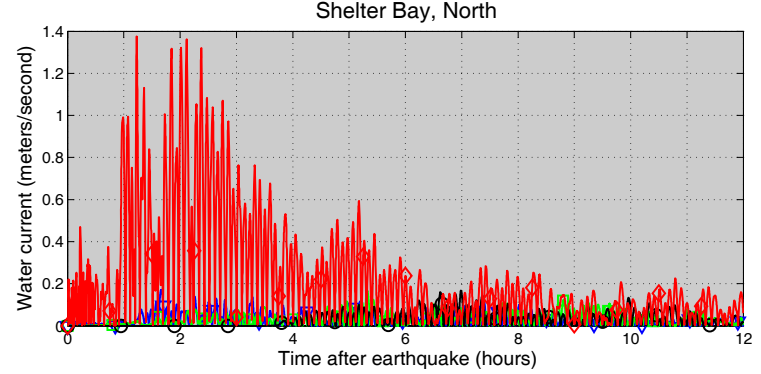

Pre-earthquake depth $81.4 \mathrm{~m},(266.9 \mathrm{ft})$ 